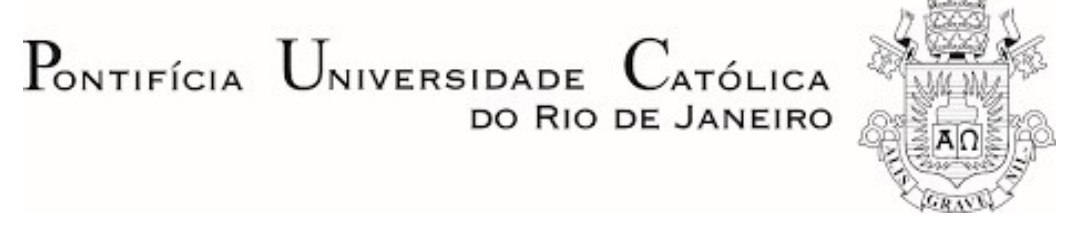

André Mesquita Penna Firme

\title{
A Ordem de Alceu: \\ História e Ação no pensamento social e filosófico de Alceu Amoroso Lima (1928-1934)
}

Monografia apresentada à Graduação em História da PUC-Rio como requisito parcial para obtenção do título de bacharel em História.

Orientadora: Prof ${ }^{a}$ Margarida de Souza Neves

Rio de Janeiro, Novembro de 2018 
Para o Anderson, sempre. 


\section{Agradecimentos}

À PUC-Rio e ao PET, agradeço pela oportunidade de tornar possível essa pesquisa que se desenrola há quatro anos.

A todos os que direta ou indiretamente foram envolvidos nesse projeto, a todas as conversas, desabafos, choros e comemorações, a todos os abraços afetuosos e broncas em momentos decisivos, eu agradeço de coração. À Ana, que em momentos de amor e de tensão soube ser a irmã mais velha que escolhi. À Juliana, que com seu abraço acalentador pôde sentar e me ouvir nos nossos infindáveis cafés. À Luísa, que também em nossos cafés construiu comigo uma conexão ímpar. À Isa, ao João, ao Eduardo e ao Victor, que sempre souberam me lembrar de quem eu sou. À Paula, tão firme por fora e tão calorosa por dentro.

À minha mãe e ao meu pai, que sempre me incentivaram a seguir os caminhos que o mundo me oferecesse, e me mostraram que o trabalho e a dedicação são as armas para que eu pudesse me constituir enquanto sujeito. Ao Raul e a Luísa que sempre me lembram da responsabilidade e da cumplicidade e do amor de ser irmão mais velho.

Aos dois mestres que marcaram a minha formação de modo tão profundo e radical que mesmo se os abandonasse nesse instante - erro que não cometerei ainda assim teriam suas marcas profundamente entranhadas no quem eu me tornei nesses anos de formação. Ao mestre que me iniciou na minha arte, Miguel Greg, dedico o mais sincero agradecimento de quem o deve parte de mim mesmo. À outra mestra, que mais do que História, me ensinou a pensar, a refletir e a escrever desde os primeiros momentos da faculdade, e que me mostra constantemente, de forma tão sutil e calorosa, os caminhos de um longo trajeto à frente, dedico à Guida todo o (pouco) que até hoje caminhei dentro da Universidade.

Além dela, aos colegas do Núcleo de Memória, à Silvia que foi também uma professora de profissão para mim. Ao Clóvis e ao Edu, ao Matheus, ao Miguel e ao Rodrigo. Aos colegas de período e aos que adotei de outros períodos, nesse departamento tão aberto e caloroso. 


\section{Resumo}

A monografia analisa a produção de Alceu Amoroso Lima na revista $A$ Ordem, no período de 1928 a 1934. Associando essa documentação às outras publicações do autor e à sua trajetória ao longo décadas de 1920 e 1930, é possível compreender os diálogos que o autor trava com o seu período e com a tradição a qual se filia a partir de 1928, o catolicismo de teor militante. A partir da ação católica, Alceu constrói um pensamento baseado na construção de um passado ideal, identificado com o período colonial brasileiro, no qual a catolicidade supostamente reinaria em sua máxima expressão. Ao inserir a Igreja no correr processual da história, ele identifica a presença de alguns homens que alcançaram a eternidade através de sua santidade. Processo e exemplaridade ganham em Alceu contornos de um pensamento católico conservador que se formava. A partir dessa construção histórica, pode dar as bases da ação possível no mundo a partir de duas frentes: a educação e a questão social, dois focos de disputa no período entre os diversos grupos que disputavam o poder, principalmente a partir de 1930. A crise dos anos 1920 e a revolução de 1930 se tornam capitais para se entender a construção do pensamento de Alceu enquanto itinerário o grupo católico.

\section{Palavras-Chave}

Pensamento Católico; Alceu Amoroso Lima; Modernismo; Revolução de 1930; educação. 


\section{Sumário}

Introdução....................................................................................................................................

Capítulo 1 - Modernos Vetores......................................................................16

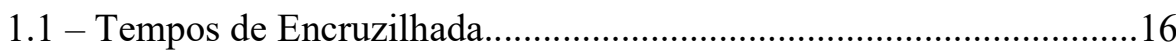

1.2 - Os caminhos da década entre São Paulo e Rio.................................25

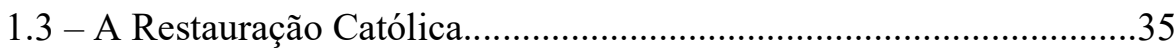

1.4 - Tempos de tradição e ação..............................................................44

Capítulo 2 - A Ordem como Itinerário..................................................................53

2.1 - Uma revista de cultura católica....................................................53

2.2 - O intelectual e o itinerário..........................................................63

2.3 - As duas faces da história..............................................................73

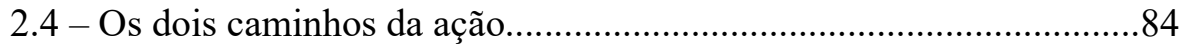

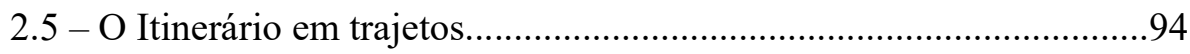

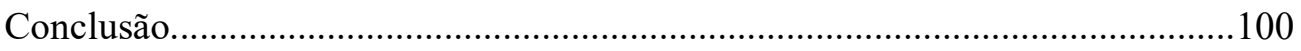

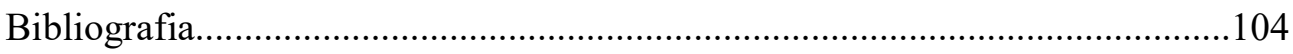

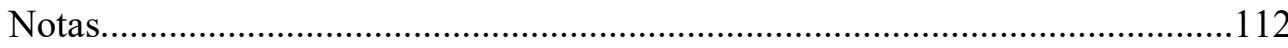


"Deus não descansa jamais"

Paul Gaugin 


\section{Introdução}

Foram muitos os modos que pensei para introduzir o texto que agora se apresenta em sua versão final, e muitas foram as dúvidas que se mostraram frente a cada possibilidade. Diante de um trabalho ao mesmo tempo tão iniciático e tão amplo, as primeiras linhas - estas que agora escrevo- foram sem dúvida as mais difíceis. É um trabalho iniciático porque, como monografia de conclusão de curso, é um trabalho de formação e de pouco impacto no mundo acadêmico. É, ao mesmo tempo, tão amplo em significado para aquele que o escreve, porque ocupa o lugar do primeiro texto extenso e de cunho autoral das vidas que doravante desaguam no mundo como historiadores formados.

Poderia começar descrevendo o ano crucial deste estudo, o momento em que é definido o rumo do ator principal para este trabalho, já presente no título como objeto e sujeito de pesquisa. Se assim fosse, poderia dar início com aquela típica referência temporal que dá o ponto inicial a inúmeros textos historiográficos. Começaria, portanto, com algo como: “O ano é 1928, quando Alceu Amoroso Lima se converte ao catolicismo". O tom poderia ser dramático, explanatório, ou apenas definidor do contexto em que se insere o autor.

Se quisesse me arriscar com formas mais audaciosas, poderia especular sobre a cena de Amoroso Lima entrando na Igreja para ser abençoado, no momento de sua conversão - ou reconversão, como ele mesmo chama - ao catolicismo. $\mathrm{O}$ ar de mistério poderia pairar sobre uma introdução que velasse seu objeto principal até que fosse gradualmente revelado pela narrativa. Dessa forma, envolveria um possível leitor em uma aproximação com o tema ao se deparar com o curso dos acontecimentos.

Em um primeiro momento, contudo, devido à impossibilidade de acertar com começos enigmáticos ou suntuosos, talvez a tarefa central fosse apresentar o personagem principal da pesquisa, que ocupa, desde o título até as últimas linhas, o lugar de fio condutor de uma análise que o transborda. Crítico literário, industrial, burguês, católico, intelectual. Muitas foram as definições que ao longo da vida carregou Alceu Amoroso Lima, e pelo menos dois foram os nomes pelos quais respondeu. Foi conhecido também pelo pseudônimo Tristão de Athayde, com o qual assinava sua coluna literária e alguns de seus livros e textos 
publicados. Sua vida foi longa e sua atuação no mundo político e cultural, intensa. Por isso mesmo, ao longo da sua trajetória ocupou diversos lugares distintos no contexto social, intelectual e simbólico da sociedade brasileira. Os caminhos de Amoroso Lima mostram as mudanças de um intelectual que marcou o século por sua mobilidade. Do crítico literário desvinculado de grupos artísticos específicos em sua mocidade nos anos 1920 ao católico modelar dos intelectuais ligados à Igreja na década de 1930, herdeiro de Jackson de Figueiredo; do cruzado militante à serviço da hierarquia eclesiástica da era Vargas ao Amoroso Lima do Concílio Vaticano II, defensor das liberdades e da Igreja do povo em tempos de Ditadura Militar, as veredas sinuosas pelas quais passou o itinerário de Amoroso Lima pelo século por vezes ganharam contornos, na memória construída acerca de sua trajetória, de rupturas radicais. Uma análise mais aprofundada de seu pensamento ao longo do tempo mostraria contudo que o Dr. Alceu - como era conhecido por aqueles à sua volta já em tempos de maturidade - nunca foi dado a rupturas grandiloquentes ${ }^{1}$.

A sua conversão ao catolicismo em 1928 é de extrema importância para que entender não somente a análise desse trabalho, mas toda a trajetória de Alceu. Já consagrado como o principal crítico da geração modernista - movimento que ao longo da década de 1920 havia ganhado centralidade nas discussões culturais do país -, sua conversão causou espanto a muitos contemporâneos como Mário de Andrade e Sérgio Buarque de Hollanda, que expressaram publicamente seu descontentamento com os rumos do crítico. Desde 1919, Amoroso Lima publicava semanalmente sua coluna literária no periódico O Jornal, e ao longo da década seguinte ganharia destaque, lançando alguns nomes à cena pública e criticando outros. Apesar de não ter se vinculado a nenhum grupo específico, sua crítica seguiu sua geração e as propostas da estética modernista desde antes da Semana de Arte Moderna em 1922. Consolidado seu lugar proeminente, causava espanto sua conversão principalmente pelo caráter militante de que se revestia o recém convertido, influenciado por nomes como Jackson de Figueiredo e Leonel Franca e pela perspectiva de recuperação do mundo pela moral católica.

Talvez fosse interessante, ainda, começar por falar da criação de teor elitista em seus anos de formação. Nascido em 1893 e tendo crescido no número 2 da estrada do Cosme Velho, vizinho do já velho Machado de Assis, Alceu em suas memórias $^{2}$ relembra a instrução particular que recebeu de João Kopke, que 
naquele tempo era já professor consagrado. Amoroso Lima lembra com carinho dos métodos de alfabetização inovadora de Kopke, a quem atribui anacronicamente o atributo de predecessor das inovações na educação que seriam postas em discussão décadas depois. Relembra que o professor particular ensinava a ele e a um criado da casa enquanto caminhavam pela grande chácara do Cosme Velho, a partir de cartilhas com imagens e palavras, e que só aprenderia as letras do alfabeto individualmente já mais velho, prestes a ingressar no Ginásio Nacional, como chamava-se então o atual Colégio Pedro II.

Kopke é lembrado por Amoroso Lima em suas memórias como um dos mestres que cruzaram a sua vida. Mestres, segundo ele, porque, mais do que professores, não só transmitiam ensinamentos, mas eram homens de cultura que ensinavam a viver. Para ele, a cultura era o cerne de uma formação mais profunda, entendendo-a como "aquilo que fica em nós do esquecimento daquilo que aprendemos" 3 . Ao lado de João Kopke na infância, na adolescência o nome de Sílvio Romero, já como professor da Faculdade de Direito, é evocado como outro mestre que teria, segundo Alceu, sido central na sua formação.

A passagem pelo Ginásio Nacional é tomada pelo autor como um esforço do pai - em recusa, nas suas palavras, à educação piedosa dos "colégios de padre" para que o filho pudesse frequentar um colégio junto a jovens de diversas classes sociais. Industrial do Distrito Federal, dono de uma fábrica de tecidos que seria herdada pelo filho, Manuel José Amoroso Lima, pai de Alceu, acreditava que ele precisava conviver com os filhos de famílias de trabalhadores e de classe média baixa em um colégio "popular". Com isso, "contrariava a tendência da generalidade das famílias a que me achava ligado pelo nascimento e condição social" 4 .

Evidentemente, essa contrariedade nos serve menos à compreensão de sua formação e mais da construção de sua memória e do lugar que ocupa já nos anos 1970 - quando suas entrevistas dadas a Medeiros Lima são transcritas e compiladas no livro Memórias Improvisadas. Talvez seja por aqui, pelas memórias de e sobre Alceu, que eu deva começar efetivamente.

Essa memória, a que contribuiu o próprio Amoroso Lima, consolidou a partir dos anos 1970 a imagem de um intelectual defensor da liberdade, um acadêmico preocupado com a população e com os direitos fundamentais do povo. Construiu a imagem de um homem plural, aberto, que acreditava na harmonia 
entre as classes e no respeito mútuo. É nesse sentido que Antônio Carlos Villaça define recorrentemente Alceu como um defensor da liberdade, um liberal, de natureza acadêmica ${ }^{5}$. Em Memórias Improvisadas, muitas vezes, sua vida é tecida através das sucessivas influências intelectuais que recebeu ao longo do tempo. As memórias do intelectual são, portanto, também intelectuais, e a trajetória toma a forma de uma linearidade em que influências se sucedem, moldando o pensamento do agente como um desenvolvimento racional. Fica claro no início do livro de memórias a linearidade com que se encadeiam e se sucedem as influências de Kopke, Silvio Romero e Henri Bergson - este último, filósofo francês de grande proeminência no início do século XX -, todos seus professores em alguma altura da vida. Alceu se aproximaria cada vez mais das discussões filosóficas em curso na Europa, em especial com Bergson, cujos cursos frequentou durante sua estada em Paris em 1914, tendo voltado ao Brasil já após o início da Grande Guerra. Ao que denomina influências de presença, na mocidade, ele ainda adiciona três influências literárias: Eça de Queirós, Machado de Assis e Anatole France, autores centrais na formação da juventude da época, segundo ele. Desse modo, compõe o quadro do ceticismo jovem que afirma ser característico de sua geração naquela época.

A todo momento, Alceu relaciona suas memórias pessoais com o que entende como um sentimento de geração. Nele, percebe, a partir de seus próprios caminhos, os caminhos de seus companheiros e, a partir desses trajetos distintos, identifica o sentido das buscas de seus contemporâneos. Essa trajetória se desenvolveria, ao longo de sua mocidade, como um movimento do alheamento ao engajamento. É nesse sentido que percebe a falta de comprometimento, o diletantismo, definido por ele, de uma geração que não se sentia ligada ao mundo ou a alguma causa. Essa memória do esvaziamento, interpretado como um sentimento burguês de não comprometimento, resultava na falta completa de sentido para a vida. Só com a Grande Guerra e com o fim do sonho civilizatório europeu sua geração teria acordado para o perigo de tal diletantismo e buscado cada vez mais engajar-se em projetos.

A dissolução do sentimento de ligação com uma Europa que outrora fora o grande bastião civilizatório e que então mostrava sua verdadeira face ensanguentada e destruída teria feito seus companheiros de geração, como ele mesmo, buscar na própria terra os laços que os uniam e que poderiam dar sentido 
ao mundo a partir de então. Essa memória, é preciso dizer, que confere à primeira geração modernista um lugar de vanguarda na busca do nacional, é, antes de tudo, uma construção posterior que, ao rememorar, confere sentido ao desencadeamento de fatos de forma retroativa. Como qualquer exercício de rememoração, Alceu tece o caminho de sua vida e confere significado às suas escolhas a partir do futuro consumado.

Essa construção, no caso de Amoroso Lima, ganha contornos interessantes no momento em que se conecta com a própria memória que foi consolidada sobre o movimento modernista. A relação não é arbitrária, principalmente devido ao fato de que, como afirma Saulo Gouveia, é Alceu, junto com Mário de Andrade, que constituem em primeiro lugar o que chama de "Narrativa Mestra do Modernismo" 6 . Uma narrativa que define a primeira geração modernista como absolutamente inovadora e a primeira a preocupar-se com os aspectos nacionais e que já há algumas décadas é questionada - fora consolidada, segundo Gouveia, nos anos 1940 a partir das análises de Alceu e Mário sobre o movimento. Nas Memórias Improvisadas, Amoroso Lima iria tecer os caminhos de sua vida firmemente atrelados aos de sua geração, nessa narrativa então consolidada.

É a partir dessa trama tecida por ele que ganham sentido a sua mocidade, a sua crítica literária e, posteriormente, a sua conversão, em 1928. O período a partir de 1928, passando pela Revolução de 1930, é compreendido como de impossibilidade do que ele chama de alheamento, em que o engajamento seria inescapável. Assim, justifica sua conversão quase como uma entrada no mundo, dando adeus à disponibilidade - título de um texto que escreve no mesmo ano - e entrando em um mundo de ação. Assim tece os fios de sua memória, que ficariam marcados na memória que dele se constituiu após sua morte, em 1983, aos noventa anos. Essa teria como fio principal uma frase recorrentemente repetida em entrevistas, em que diz:

Geralmente somos amigos da liberdade quando moços e partidários da disciplina quando velhos. Literariamente e até sociologicamente, fui amigo da disciplina na mocidade e amigo da liberdade na velhice. ${ }^{7}$

A construção da memória de Alceu dá sentido a sua trajetória como um caminho que vai da disciplina à liberdade. Se no início da sua vida foi um defensor da ordem, da tradição, da religiosidade, como ele afirma, o trajeto de amadurecimento o teria levado a defender as liberdades já em sua velhice. Este início, no caso, é entendido como o momento da conversão, que o teria levado a 
atuar politicamente. No entanto, ele mesmo define como só a partir da morte de Jackson de Figueiredo, no mesmo ano, adotaria totalmente a doutrina disciplinadora da ordem defendida por Jackson.

Ao longo da década de 1920, nos anos anteriores à sua conversão, Amoroso Lima trocou intensamente correspondências com Jackson, líder de um grupo de intelectuais católicos que girava em torno da revista A Ordem, exerceu no crítico uma influência importante. Seu processo de conversão, como ele mesmo chama atenção, se alongou durante anos de intensa discussão. Mesmo que para aqueles que estavam à sua volta tal mudança pudesse parecer uma metamorfose repentina, a conversão pode ser melhor entendida pela ideia - vinda do léxico religioso - de metanóia, como um processo de mudança de pensamento e arrependimento que acontece ao longo do tempo, continuamente. Ao discorrer sobre as conversas com Jackson, ele marca bem a diferença entre o pensamento autoritário do mesmo e a sua própria dimensão anti totalitária, "antitradicionalista, colocando sempre a liberdade acima da autoridade" ${ }^{8}$.

Só após a morte de Jackson que, segundo Alceu, sua influência estaria completa. Herdando a posição do mestre como diretor do Centro Dom Vital: "a partir daí caminhei numa outra direção, passando do liberalismo anterior para uma posição ortodoxamente autoritária, baseada no sentimento da disciplina e da ordem." 9 .

Assim, o caminhar para o "sentido da liberdade" na velhice envolve-se, a partir do tecido da memória, em um sentido de retorno às convicções anteriores e propriamente suas, em oposição à absorção que fizera nesses anos do pensamento jacksoniano. A memória do período de recém convertido ganharia uma dimensão de fuga de si mesmo, para retornar a si nos anos de maturidade.

É sintomático que, neste caso a memória da vida de Amoroso Lima esteja sendo construída em um momento já avançado da sua vida, e que suas convicções mais aguerridas dos anos 1930 sejam vistas quase como um desvio. Poderia ser feita uma análise de como a memória sobre ele alterou-se ao longo do tempo tendo em vista seu livro de memórias e comparado-o com as duas biografias escritas sobre ele: a primeira publicada no ano de sua morte, em 1983, por Antonio Carlos Villaça, intitulada Desafio da Liberdade, e a segunda por seu neto em 2015, intitulada Histórias de meu avô Tristão. Infelizmente tal estudo, muito 
além do fôlego deste trabalho, ainda deverá aguardar um futuro para que possa ser feito.

Suas memórias, contudo, já nos anos 1970, no fim da vida, fazem em parte o trabalho que através de seu pseudônimo fizera ao começar sua trajetória de crítico em 1919. Ao ser chamado para publicar uma coluna literária n’O Jornal, decidira assinar sob o pseudônimo de Tristão para que sua produção não fosse confundida com sua atuação industrial. Em 1918, Alceu herdara do pai a posição de presidente da Companhia de Fiação e Tecidos Cometa, cargo que exerceria até 1937. Esta posição preocupou o crítico iniciante, receoso que pudessem confundir sua atuação de industrial com a de crítico. Por isso, passa a assinar com o nome Tristão de Athayde. Essa estratégia, que buscava desvincular o crítico das questões sociais, começa a esgotar-se quando Amoroso Lima passa a ser conhecido ao longo da década de 1920. Seus dois nomes, Alceu e Tristão, a partir de certo momento passariam a ser usados de modo intercambiável para referir-se a ele. No entanto, durante o período que este trabalho analisa, ele ainda assina os seus trabalhos com o pseudônimo, salvo nos momentos em que o assunto o concerne pessoalmente, como no texto que publica em homenagem a Jackson. Para ele o autor - Tristão - não poderia ser confundido com a pessoa - Alceu.

$\mathrm{Na}$ construção de suas memórias também sua trajetória intelectual é tecida em grande parte de modo a velar sua condição de industrial. À consciência da trama do intelectual ativo, foi negada a presença inescapável da urdidura do agente social pertencente à nova burguesia urbana industrial que ganhava força no Brasil no início do século. Se, a essa trama, não pudermos entrelaçar a urdidura do caráter social de Alceu enquanto agente social, não poderemos tecer com precisão a tapeçaria de sua vida, assim como os tecidos produzidos pela fábrica que então herdara de seu pai não poderiam ser produzidos apenas por fios em paralelo.

É tendo isso em mente que se pode traçar, como o faço no primeiro capítulo deste trabalho, os caminhos das estruturas sociais e simbólicas que na década de 1920 reordenam o campo político e cultural brasileiro. É a partir do entendimento preciso do lugar que Amoroso Lima ocupa na sociedade brasileira que se poderá compreender como ele age e reage ao meio em constante mudança, como absorve e propõe formas de se relacionar com o mundo, política, social e esteticamente. É a partir disso que se poderá relacionar, no segundo capítulo, como o seu pensamento constrói e dá a entender o mundo à sua volta. Como o ataque ao 
mundo burguês ganha o tom de um combate cultural e moral, mas raramente estrutural, e o combate ao comunismo se insere em sua análise histórica. Como esse combate que toma forma, em seus textos, de uma crítica de caráter intelectual, não podem ser separadas das tensões que teve com a ANL, que chegou a acusar a Cometa, indústria presidida por Alceu, de utilização de trabalho infantil e de oferecer condições de trabalho degradantes ${ }^{10}$.

Talvez seja precisamente esse o ponto central de uma introdução como essa, afinal de contas. Mostrar as bases sobre as quais faço minhas observações no texto que se segue, e como essas observações se encadeiam ao longo do texto. Nos dois capítulos da monografia, faço uma análise da obra publicada por Amoroso Lima nos anos entre 1928 e 1934. Nesse período, entre sua conversão e a primeira constituição da era Vargas, momento em que mais publicou durante toda a sua vida - escreve vinte livros em sete anos, além de seus artigos para A Ordem e outros periódicos - Alceu organiza um certo tipo de pensamento que deveria servir de base para guiar a construção de um conhecimento fundamentalmente baseado na moral católica. Para que isso seja possível, o primeiro capítulo busca compreender o contexto em que se insere o autor nesses tempos, do esgotamento dos anos 1920 à abertura do início dos anos 1930.

Esta pesquisa, como todo projeto a essa altura das nossas vidas, começou mais ambiciosa do que seria possível levar adiante. Em um projeto preliminar, buscava analisar o pensamento de Alceu estendendo-me até 1945. Isso porque o primeiro contato que tive com o autor foi ainda em meu primeiro ano de iniciação científica, quando decidi pesquisar a fundação da Pontifícia Universidade Católica do Rio de Janeiro em 1940. Ainda no segundo ano de faculdade, em meu primeiro ano como bolsista do Núcleo de Memória da PUC-Rio, queria entender as bases, o contexto e a justificativa para a construção, naquele momento e naquele lugar, de uma universidade católica ligada à Santa Sé.

Foi desse modo que me aproximei de nomes como os de Alceu Amoroso Lima, do padre Leonel Franca e de Dom Sebastião Leme, três dos principais atores na fundação da Universidade. Com o tempo a pesquisa focou-se em Amoroso Lima, em especial pelo interesse de compreender o lugar que um tipo de intelectual como ele ocupava na sociedade. A partir daí pude perceber como as disputas intelectuais revestiam-se de disputas simbólicas, e como os temas comuns entravam nas discussões a partir do momento que os diversos grupos 
viam neles posições valiosas de construção de uma visão de mundo que pudesse justificar uma ação efetiva na sociedade. A ordenação que Alceu faz do mundo e a ordem que ele insere no mesmo não estão desvinculados dos processos políticos, sociais ou até mesmo urbanos daquele período. Pelo contrário, a disputa simbólica buscava exatamente o poder que conferisse legitimidade à ordenação da cidade letrada que estava em jogo ${ }^{11}$.

Algumas dessas ordenações podem ser percebidas até hoje, a partir dos signos que mantiveram-se através dos tempos. Seja nas vielas, alamedas e prédios da PUC-Rio, que carregam os nomes daqueles que marcaram sua trajetória - como a alameda Alceu Amoroso Lima ou os edifícios Cardeal Leme e Leonel Franca -, seja nas intervenções e reverberações na cidade, para aquele que domina sua leitura, "há um labirinto de ruas que só a aventura pessoal pode penetrar e um labirinto dos signos que só a inteligência raciocinante pode decifrar, encontrando sua ordem" 12 .

Por isso, ao contrário do que nos sugere o crítico, preferi utilizar o próprio nome de Amoroso Lima neste trabalho, por entender que sua produção, seja de tecidos, de signos ou de influências, não está desvinculada do homem que descia do Cosme Velho - e posteriormente das Laranjeiras -, e se dirigia, a pé, de bonde ou como fosse, à Praça XV, onde ficava o Centro Dom Vital. Em última instância, assim como numa carta de Jackson de Figueiredo, posso dizer que "é porque Tristão é Alceu que Tristão me interessa" ${ }^{13}$. 


\section{Capítulo I - Modernos Vetores}

\subsection{Tempos de Encruzilhada}

A população saía de suas casas às pressas na madrugada do dia 27 de janeiro. Confusos, assustados, a noite fora marcada pelo susto dos moradores diante do abalo sísmico que pegou de surpresa os moradores de São Paulo naquele início de 1922. Às quatro da manhã, o povo, que a essa hora dormia tranquilamente, foi sendo acordado pelos tremores de terra que, tão logo vieram, não tardaram cessar. Após a breve tempestade de susto e incerteza, a população dificilmente voltaria aos seus cômodos, tão pouco dormiria tranquilamente, como informa a edição de 28 de janeiro d'O Jornal ${ }^{14}$. Em meio a notícias de greves na América do Norte, da nova exposição de arte retrospectiva no Museu de Belas Artes, na Cinelândia, e da feira internacional do livro em Florença, o periódico divulgava as notícias vindas da capital paulista e as análises de seus efeitos. $\mathrm{O}$ terremoto teria afetado principalmente as cidades no triângulo entre a capital paulista, o Rio de Janeiro e Poços de Caldas, em Minas Gerais. A página do Correio da Manhã desse mesmo dia afirmava que os efeitos sísmicos foram sentidos também em Petrópolis, "não tendo registado qualquer desastre" 15.

Os assustados moradores de São Paulo àquele momento não poderiam prever a quantidade de abalos sísmicos o país sofreria ainda naquele simbólico ano de 1922. Explícitos ou não, o ano do centenário da independência do Brasil não marcaria ainda nenhum fim, mas inúmeros começos, quebras, que pelas brechas de uma estrutura em vias de esgotar-se, reorderariam as placas tectônicas há tanto tempo em movimento, mas que a partir de então passariam a colidir-se entre si. Esses abalos - simbólicos abalos - mais do que começos explosivos e retumbantes, marcavam reordenações no campo simbólico em vias de se reestruturar.

$\mathrm{O}$ ano que marcou o centenário da independência foi palco de inúmeros eventos que, se não foram marcantes para seus contemporâneos, ganharam sua dimensão com o desenrolar da história. O Rio de Janeiro, capital federal, foi palco da Exposição Internacional. Celebrações da crença no progresso como lei da história, a partir de 1850 e, em especial, na virada do século XIX para o XX, as exposições internacionais foram uma verdadeira festividade dos avanços técnicos 
internacionais, constituindo uma verdadeira vitrine ${ }^{16}$ do que se pretendia ser o mundo civilizado. Essa festa do progresso contava com participação de vários países e cada um, em seu pavilhão ou espaço próprio, apresentava o que tinha de mais novo e representativo. Palco da exposição em 1922, a capital do Brasil demonstrava a força de seu passado em sua modernidade e buscava marcar seu ingresso definitivo no concerto das nações civilizadas e progressistas. $\mathrm{O}$ marco da Exposição no Brasil como ingresso na modernidade, contudo, apesar de um projeto político central pelo governo brasileiro, já não carregava a significação que outrora tais exposições envolviam. Compreendidas como arena pacífica do mundo civilizado, as exposições evidenciavam supostamente a oposição entre a civilização - que em seu estágio evolutivo prescindiria das guerras do passado - e a barbárie dos povos primitivos - violentos e em constante conflito. Ora, esse imaginário, que permeou o sonho da Belle Époque europeia, caiu por terra com a Grande Guerra iniciada em 1914. Ao sonho da sociedade civilizada e livre dos conflitos, contrapôs-se o horror da guerra e da mobilização armada. As exposições internacionais, antes palco do desenvolvimento dos povos e evidência do fim dos conflitos armados, esvaziaram-se de seu significado primevo.

Se este esvaziamento pode explicar a possibilidade, após 1918, de que uma exposição fosse feita em um país tão periférico, não era isso que tinham em mente os oligarcas brasileiros. A exposição ainda era vista como a possibilidade de mostrar ao mundo, finalmente, a grande trajetória da sociedade brasileira que modernizava-se. A forte eloquência da valorização do século que havia decorrido desde a independência fazia contraste com as novas formas de produção e ação política e social. Nesse mesmo ano, quatro eventos marcam novas perspectivas, quatro começos, que indicam uma insuficiência - aos olhos destes homens - dos mecanismos vigentes até então. A fundação do Partido Comunista Brasileiro (PCB), A Semana de Arte Moderna em São Paulo, A fundação do Centro Dom Vital e a revolta do Forte de Copacabana marcaram os primeiros episódios dessa rearrumação de forças em 1922. Cada um deles traziam propostas e formas novas de organização social. No campo do trabalho, artístico, religioso e militar, esses diversos começos indicavam reordenações, como será analisado mais adiante, de formas e estruturas que veriam seu esgotamento na década nascente.

No dia seguinte ao terremoto, na edição do dia 29 de janeiro d'O Jornal, a coluna "Vida Literária", assinada por Tristão de Athayde, trazia a análise de 
quatro publicações do ano anterior. Ao escrever sobre estética, narrativa, entre outros assuntos, o crítico que ao longo da década se firmaria como figura importante no cenário artístico carioca dava especial ênfase ao texto de Flexa Ribeiro, Narciso, sobre o qual chama atenção para o sensualismo e o intuicionismo moderno que trazia consigo uma estética que não se prende à lógica para explicar o mundo. O impressionismo literário, que define como a liberação do subconsciente por esse intuicionismo, é celebrado na obra de Flexa Ribeiro, ao passo que é criticado no caráter pretensamente impressionista de Águas Fortes, do estreante Augusto Gonçalves de Sousa Júnior ${ }^{17}$.

Os ventos da modernidade já eram sentidos ${ }^{18}$. Os caminhos estéticos e políticos eram trazidos pelos movimentos tectônicos que já indicavam as mudanças por vir. E foram sentidos através do esgotamento das estruturas da Primeira República, que desde a Reação Republicana, passando pelos eventos de 1922, ao ponto de, em 1928, ao falar de sua conversão, Alceu Amoroso Lima afirmasse em entrevista citada por Antonio Alcantara Machado:

Se não fosse católico, seria comunista. É que a época é de militantes. Cada vez mais se admite menos a existência dos furta-cores ou dos multicores. A gente é ou não é. Não é possível, hoje, ao intelectual [...] aquele alheamento que já foi regra e chegou a ser orgulho da irritável classe. Agora tudo é ação social. Queira ou não queira, o homem é empurrado para a encruzilhada, posto diante do dilema: tem que decidir, os problemas se apresentam como de vida ou de morte. E chega por isso o momento em que o instinto de defesa acaba vencendo a covardia e o comodismo. ${ }^{19}$

Essa dimensão aparece também nos dois testemunhos de convertido de Amoroso Lima, textos publicados no momento de sua conversão, e que atestam a mudança de rumos do intelectual. Em "Adeus à Disponibilidade" (1928), carta aberta às críticas feitas por Sérgio Buarque de Hollanda, afirma estar lutando contra uma tentação quase adolescente de não se comprometer, um alheamento que seria romantizado por um tipo de pensamento ingênuo, e que o homem, "por excesso de liberatismo, [estaria caminhando] para a servidão" ${ }^{20}$, e que o comprometimento seria não uma amarra, mas a verdadeira libertação. Em Tentativa de Itinerário (1929), afirma que a beleza da juventude consiste exatamente em abraçar uma causa, coisa que há meio século havia perdido ${ }^{21}$.

Tais posturas adotadas por Alceu explicam em parte a polêmica e assertiva afirmação anterior: "se não fosse católico, seria comunista". Aparentemente contraditória para os termos da época, a frase precisa um ponto de engajamento específico. No ano - 1928 - em que o Bloco Operário e Camponês (BOC) se 
firmava como ator na dinâmica política associado ao PCB e que a crise das oligarquias tradicionais era sentida entre cisões e disputas, é significativo que, para um intelectual investido nos rumos do país, essas fossem as duas formas de engajamento total no encaminhamento político da nação. Sobre os novos atores políticos surgidos de grupos intelectuais, Sérgio Miceli identifica a passagem de um ideal político clássico - aquele que separa política e letras - para um novo tipo de olhar, patente nos casos de Antonio Alcantara Machado e Guilherme de Almeida, que "prenunciavam a impossibilidade de reproduzir a carreira e o itinerário político de seus pais" ${ }^{22}$. Essa nova forma de construir um itinerário político está dada nas inúmeras propostas e alternativas que são postas em jogo nos anos de 1928-29. O modernismo, a essa altura, como se verá, se divide em diversas correntes e propostas, itinerários, por assim dizer, para os rumos culturais do país. Sérgio Buarque, em oposição aos rumos de Amoroso Lima, defende que se deve "viver em mobilidade", longe dos idealismos fáceis ${ }^{23}$. Ao contrário, no entanto, "o momento era refratário à prudência e circunspecção, desprezando a mobilidade em louvor da mobilização ${ }^{24}$.

Em 1928, o Manifesto Antropofágico, de Oswald de Andrade e Macunaíma, de Mário de Andrade, revitalizam o cenário do modernismo. Retrato do Brasil, de Paulo Prado, apresenta um quadro histórico da crise vivida pelo Brasil, "fazendo um balanço das alternativas drásticas que se ofereciam" ${ }^{25}$, afirmando que as soluções terapêuticas para os males políticos e sociais não mais faziam efeito, e que se deveria recorrer à cirurgia, ou seja, para solucionar os problemas do Brasil, apenas a guerra ou a revolução. Amoroso Lima identifica o livro de Paulo Prado, junto com Bagaceira, de José Américo de Almeida, como os dois grandes sucessos do ano de 1928 e que trazem o espírito de "desliteralização da literatura" que vinha sendo produzida ${ }^{26}$. O fator marcante do ano de 1928 teria sido, apesar de sua inexpressividade em termos editoriais, o aparecimento de "revistas literárias marcando as tendências diversas da nossa atualidade" 27 . Além da Revista de Antropofagia e da nova forma d'A Ordem, chama atenção para o surgimento de Festa, com uma proposta espiritualista dentro da estética modernista, do grupo dinamista em torno da revista Movimento Brasileiro e dos marxistas da revista Cultura. A efervescência de propostas novas e de itinerários de engajamentos continuam no ano seguinte. Em 1929, o manifesto Nhengaçu Verde-Amarelo inaugura o Verde-Amarelismo como um modernismo voltado 
para o passado mítico, nacionalista e fundamentalista, tendo a frente Plínio Salgado e Cassiano Ricardo. Os dois viriam a ocupar lugares importantes na configuração política na década seguinte, sendo o primeiro o fundador e líder da Ação Integralista Brasileira e o segundo um intelectual chave para as articulações culturais do governo Vargas, em especial no Estado Novo. Ainda em 1929, Alceu já identifica um "convencionalismo modernista, que é preciso combater decididamente", e que a "brasilidade forçada da literatura (...) é tão falsa quanto sua imbrasilidade" ${ }^{28}$, concomitantemente à critica de Alcantara Machado ao afirmar que escrever "brasileiro" tinha virado moda ${ }^{29}$.

O tenentismo já havia se firmado como modo de ação política eficaz e legitimado, e mesmo que desde 1927 a Coluna Prestes tivesse se dissolvido e deixado de atuar, o imaginário revoltoso tenentista ainda rondava a imaginação de muitos. A cisão interna na oligarquia paulista tinha levado à criação, em 1926, do Partido Democrático, que mais tarde se aliaria às oligarquias estaduais secundárias na formação da Aliança Liberal.

Edgar de Decca afirma justamente que "no período de 1928 existiam em São Paulo pelo menos três propostas de revolução vindos de agrupamentos políticos diferentes: o Partido Democrático, os 'tenentes' e o Bloco Operário e Camponês" ${ }^{30}$. Tendo como base de análise os movimentos de classe, chama atenção para formas revolucionárias que podem ser identificadas por uma oposição interna da elite agrária, um bloco militar ligado a propostas da burguesia urbana ${ }^{31}$ e um ligado às classes trabalhadoras e camponesas. "Havia, portanto, lugares diferentes definidos pelo termo revolução e a possibilidade de se encontrar um acordo entre as diversas propostas políticas" 32 .

A forte presença do ideário revolucionário e da dimensão da mobilização e da ação propiciaram uma conjuntura favorável à coalizão revolucionária. $\mathrm{O}$ contexto efervescente e a insatisfação geral, associados à crítica que os intelectuais modernistas faziam ao desengajamento reflexivo, propiciaram as condições para que fosse levado a cabo a ruptura da continuidade republicana, a primeira desde a Constituição de 1891.

Como ainda afirma De Decca, a construção da memória histórica proporciona, como proporcionou, a lembrança e o esquecimento de acordo com os interesses políticos aos quais a construção dessa narrativa se vincula. É nesse sentido que ele denuncia o esquecimento da presença e participação dos 
trabalhadores do Bloco Operário e Camponês (BOC) na revolução. Mais do que isso, Getúlio Vargas, a partir da tomada do poder, se esforça a construir uma narrativa da revolução que possa tecer os elementos que a preexistiram e que foram legitimados ao longo das disputas políticas. Nesse tecer narrativo os elementos principais e que a partir do final da década de 1920 ganharam centralidade no imaginário comum se desenham com clareza. O tenentismo se torna "moeda cobiçada no processo revolucionário de 1930, pois representa o mais legítimo representante do interesse nacional e tinha um relativo conteúdo popular" 33 . Por mais que a composição da Aliança Liberal não estivesse vinculada ao tenentismo, sua presença na articulação revolucionária conferiria um caráter legitimador ao movimento. $\mathrm{O}$ tenentismo passaria, no primeiro momento, a compor as forças que caracterizaram o governo provisório.

Além dos tenentes, outro grupo seria engolfado pela narrativa revolucionária. Em discurso, Vargas afirmava: “As forças coletivas que provocaram o movimento revolucionário do modernismo na literatura brasileira, que se iniciou com a Semana de Arte Moderna de 1922, em São Paulo, foram as mesmas forças que precipitaram, no campo social e político, a Revolução de 1930" ${ }^{34}$. Comumente associada a uma sugestão de Guilherme de Almeida a Getúlio, a associação não é em vão. Associando-se ao que identifica como as forças renovadoras da modernidade, o agora chefe do governo provisório conferia inevitabilidade ao regime instaurado. Durante seu governo irá progressivamente trazer para a tutela do Estado a produção cultural, caracterizando o processo da década de 1920 até a instauração do Estado Novo, em 1937, como a progressiva "união entre o homem de pensamento e o homem de ação, entre política e literatura, enfim, entre os intelectuais e o Estado" ${ }^{35}$. A narrativa varguista da revolução se completaria em 1937, com a instauração, pelo próprio Vargas, da ditadura que recebeu o nome de Estado Novo. Segundo Monica Velloso

a ideia de que a revolução literária, pondo em xeque os modelos importados, estaria completa com a revolução política do Estado Novo, cujo objetivo seria o de combater os modelos políticos tidos como alienígenas, como o liberalismo e comunismo $\mathrm{O}$ ideal da brasilidade e da renovação nacional é, então, apresentado como o elo das duas revoluções, artística e política. ${ }^{36}$

Se a revolução de 1930 reordenou simbolicamente a década pregressa para se legitimar, o Estado Novo reelaborou essa narrativa a ponto de unir, como efeitos do mesmo destino manifesto, os rumos do governo Vargas com um momento fundacional. Não é preciso dizer que essa narrativa é construída pelas 
instâncias de poder que buscam legitimar-se perante a sociedade, e que não tem relação necessária com o entendimento construído no desenrolar dos acontecimentos. Basta chamar atenção para o fato de que essas narrativas construíram uma interpretação linear dos acontecimentos que trabalha como um jogo de luz e sombras. Da mesma forma que o Estado Novo construiu-se como a união derradeira entre nação e cultura, os anos do regime autoritário seriam o momento de consolidação do que Saulo Gouveia chama de "narrativa mestra do modernismo" 37 . Segundo ele, o núcleo dessa narrativa mestra foi firmado na década de 1940 pelo trabalho crítico de Amoroso Lima e de Mário de Andrade. Duas figuras diversas e quase opostas no desenrolar das dinâmicas políticas e intelectuais, os dois autores teriam consolidado uma interpretação retrospectiva do modernismo como um movimento de ruptura, que abrira caminho para uma produção verdadeiramente nacional, abrasileirada, que teria tido início na Semana de Arte Moderna e que se estenderia até o momento. Essa narrativa mestra chamava atenção para o caráter moderno da estética e pela preocupação estética, linguística e temática do que seria a construção da brasilidade. No caso de Alceu, ele ainda teria contribuído com a ideia de que alguns escritores, mesmo que temporalmente anteriores ao movimento modernista, trariam em si indícios dessa nova estética. A esses autores, dentre os quais Machado de Assis, Lima Barreto, entre outros, conferia a marca de pré-modernistas.

Esse fio narrativo construiu a ilusão de um desenvolvimento linear que direcionava os caminhos nacionais em uma direção predeterminada a priori. A linearidade entre 1922, 1930 e 1937 excluiu por muito tempo do debate o caráter extremamente pulverizado e múltiplo das propostas que estavam em jogo na década de 1920 e a partir da revolução de 1930. Como já foi visto, os anos que precederam a revolução foram de efervescência ímpar, e os itinerários se multiplicavam quanto mais se tornava patente o esgotamento das elites tradicionais. Isso não nos pode impedir de perceber os elementos que antes dos eventos de 1922 traziam já a preocupação com a estética moderna e com o pensamento nacional, e como esses dois elementos se relacionaram de forma não linear ao longo do tempo, constituindo formas e propostas múltiplas.

Além disso, é preciso entender que o caráter organicamente múltiplo da Aliança Liberal, que levou a cabo a mudança de poder em 1930, proporcionou num primeiro momento a constituição de um governo que precisava dialogar com 
programas e perspectivas políticas as mais variadas. A diversidade de programas no interior da Aliança Liberal converteu-se no que se convencionou chamar de "Estado de Compromisso". Marieta Ferreira e Surama Pinto analisam a construção do Estado pós-revolucionário em suas múltiplas reordenações:

Como nenhuma classe ou fração de classe ascende em caráter exclusivo ao Estado, o que se observa no país é um reajuste nas relações internas dos setores dominantes. O Estado de Compromisso, nesse sentido, nada mais é do que um Estado que se abre a todas as pressões sem se subordinar necessariamente a nenhuma delas. Suas principais características são uma maior centralização, com a subordinação das oligarquias ao poder central, a ampliação do intervencionismo, que deixa de ser restrito à área do café, além do estabelecimento de certa racionalização na utilização de algumas fontes fundamentais de riqueza pelo capitalismo internacional. ${ }^{38}$

Esse Estado de Compromisso proporcionou, nos anos que se seguiram à revolução, sob a promessa vaga da formulação de uma nova constituição, a sensação de abertura do campo de disputa. É nesse sentido que o editorial d' $A$ Ordem de janeiro de 1931 afirma que o Brasil se achava "em plena disponibilidade". Naquele momento, todos percebiam a incerteza que pairava no ambiente, "a multiplicidade de caminhos que se abrem em nossa frente à espera de nossa escola" ${ }^{39}$. A subversão política, afirmava Alceu, "nos coloca novamente em uma encruzilhada" ${ }^{40}$. As incertezas do regime propiciam uma rearrumação de forças nos anos seguintes. Marly Vianna, ao compor o trajeto do PCB e da Aliança Nacional Libertadora através dos caminhos políticos destas décadas, afirma que

a eclosão da Revolução de 1930 ampliou o espaço de participação política, fazendo com que os mais diversos setores da população elaborassem seus programas, se organizassem politicamente, buscassem alianças e, principalmente disputassem a liderança em ações de rua. ${ }^{41}$

A união do Partido Democrata com o Partido Republicano, em São Paulo, indicou um rechaço da política intervencionista e centralizadora do governo provisório por parte das elites paulistas, que viam seu poder reduzido. Em 1932, quando anunciada a eleição para uma assembleia nacional constituinte no ano seguinte, as pautas começavam a tomar forma. Neste ano ganha corpo a Ação Integralista Brasileira, sob a liderança de Plínio Salgado, que relacionando-se com a política fascista em ascensão na Europa, propunha uma revolução política e espiritual, sob o lema "Deus, Pátria e Família". Do mesmo ano é o Manifesto dos Pioneiros da Educação Nova, que propunha "A reconstrução educacional no Brasil - ao povo e ao governo" 42. Segundo Dulce Pandolfi, "a reconstitucionalização do país representava uma derrota para o tenentismo e os 
aliados civis", que diante desse cenário posicionaram-se de diferentes formas, uns acenando para os movimentos mais radicais, como a AIB e o Partido Comunista ${ }^{43}$. A Liga Eleitoral Católica surgiria nesse período como articulador de pautas católicas no campo da educação, questões de trabalho, dos direitos civis e no tocante à relação entre a Igreja e o Estado.

Esses anos cruciais demonstram a multiplicidade de possibilidades que estavam postas e, dentre elas, o programa católico que tinha à frente, desde 1928, Amoroso Lima. Os períodos de indefinição mostram sua potência criativa no rearranjo das propostas renovadoras. O editorial d'A Ordem percebe em janeiro de 1931 que "estamos em uma fase de explicitação. Chegamos ao momento das grandes opções. A atitude agnóstica se acha em plena decadência" ${ }^{44}$, fazendo referência à análise de que os males do Brasil eram vinculados ao afastamento da crença em Deus e da tradição católica, mas que pode ser entendido - essa "atitude agnóstica" - com o alheamento de que fala Alceu em citações anteriores. Esses anos cruciais que se anunciavam em 1928, e que em 1930 foram estabelecidos com o novo cenário político, fazem jus a seu sentido etimológico. Derivado do latim crucis, os anos cruciais que marcaram as metamorfoses sociais no país marcaram uma encruzilhada. Os caminhos se multiplicavam e a escolha poderia significar a própria sobrevivência para aqueles que atuavam. Pelo menos é isso que entende Alceu, que sob a cruz que projetava com suas sombras a encruzilhada frente a qual se viu, afirma que "escolher (...) é a nossa inserção na realidade. É pela escolha que demonstramos a liberdade, que não é senão 'a própria vontade em ação" ${ }^{45}$. Entender a forma como ele leu o seu tempo e negociou com a realidade à sua volta é o primeiro passo para que se possa entender a forma como constrói seu pensamento. Mesmo que não seja verdade para todos os atores em jogo - como na defesa da mobilidade de Sérgio Buarque -, a inevitabilidade da mobilização vista por Alceu como a única forma de manter sua liberdade frente à escravidão do alheamento alienante se relaciona de forma a negociar com o contexto em que vive.

À multiplicidade de propostas, a perspectiva vencedora imporia sua narrativa linear e infalível. Frente aos inevitáveis ventos da modernidade do discurso varguista, resta saber se a cruz, fincada na encruzilhada, resistiria aos abalos sísmicos e às movimentações tectônicas. 


\subsection{Os caminhos da década entre São Paulo e Rio - de trinta a vinte e dois e de volta}

A revolução de 1930 punha em jogo a história que a precedia. Como afirma Boris Fausto, mesmo com toda a mobilização em termos sociais, seria muito difícil prever que, após uma presidência relativamente tranquila como a de Washington Luís, surgiria uma cisão entre as elites capaz de levar ao fim da Primeira República ${ }^{46}$. Para compreender os processos que levaram à tensão capaz de interromper pela primeira vez a continuidade republicana, é preciso entender como as mudanças ao longo da década de 1920 reverberaram no campo político, social e cultural do país. Segundo Sérgio Miceli:

As décadas de 1920, 1930 e 1940 assinalam transformações decisivas nos planos econômico (crise no setor agrícola para a exportação, aceleração de processos de industrialização e urbanização, crescente intervenção do Estado em setores-chaves da economia etc.), social (consolidação da classe operária e da fração de empresários industriais, expansão das profissões de nível superior, de técnicos especializados e de pessoal administrativo nos setores público e privado etc.), político (revoltas militares, declínio político da oligarquia agrária, abertura de novas organizações partidárias, expansão dos aparelhos do Estado etc.) e cultural (criação de novos cursos superiores, expansão da rede de instituições culturais públicas, surto editorial etc.). ${ }^{47}$

Tais transformações nos planos econômico, social, político e cultural do país reverberariam, inevitavelmente, na trama simbólica que estava em constante movimento. A partir de 1918 com o fim da Primeira Grande Guerra, "a presença da classe média urbana tornou-se mais visível" ${ }^{48}$. Cada vez mais a política seria feita mais perto da população urbana. O processo de industrialização ganhava corpo junto com a expansão urbana, principalmente no eixo Rio-São Paulo. A expansão da indústria, principalmente a têxtil, na virada da década de 1920 proporcionou também uma projeção maior da burguesia urbana industrial, que estava de fora do jogo oligárquico estabelecido nas bases da Primeira República, que priorizava o setor agrário, principalmente os produtores de café. Essa expansão urbano-industrial alargava o campo de ação não só da burguesia ligada à produção da indústria, como também proporcionava uma expansão da organização política dos trabalhadores. As greves de 1917 começavam a deixar claro que a questão dos trabalhadores pouco a pouco não seria mais contornável, e as notícias vindas da Revolução Russa agravavam a tensão das elites frente a uma progressiva organização dos trabalhadores. "Nasceu assim em março de 1922 o Partido Comunista do Brasil, cujos fundadores, em sua maioria, provinham do anarquismo" 49 . Ligados à III Internacional - a Komintern - o grupo trazia uma 
perspectiva revolucionária programática e uma proposta política mais sólida do que os grupos anarquistas que até então aglutinavam as reivindicações dos trabalhadores.

Essa expansão urbana, que fora sentida de forma mais virulenta e acelerada em São Paulo - associada ao aumento expressivo do número de imigrantes compondo seu arranjo populacional -, teve na capital federal uma expressão especial. A capitalidade que marcou a cidade ao longo da Primeira República trataria de abordar as mudanças estruturais da cidade de certa forma como caixa de ressonância da política nacional. Nesse sentido, as intervenções de Pereira Passos e Rodrigues Alves na malha urbana são revestidas do imaginário de que os rumos do país estariam sendo traçados. A frase repetida por toda a campanha, "O Rio civiliza-se", ganhava contornos de uma inserção do Brasil na modernidade ${ }^{50}$. Tal inserção, ensaiada tantas vezes ao longo das primeiras décadas do século XX, fora marcada sempre por um jogo de espelhos que fazia esconder a cidade real, por trás das fachadas da Cinelândia ${ }^{51}$. Segue a mesma tradição o prefeito Carlos Sampaio, que em 1922 está a frente da administração da cidade por ocasião da Exposição Internacional. O principal impacto na cidade foi a derrubada definitiva do Morro do Castelo. Há anos em processo de demolição, a derrubada do morro e a liberação da esplanada para sediar a exposição marcam uma nova fase na política de intervenção na cidade. Sobre esse fato, Antonio Edmilson Rodrigues descreve:

O morro vai abaixo - parte de suas rochas vai parar nas muradas da Glória e na mureta da Urca (...) - e a área conhecida como Esplanada do Castelo estava liberada para a grande exposição de 1922. Interessante notar que, enquanto São Paulo, em 1922, estava comemorando o novo, com a Semana de Arte Moderna, o Rio de Janeiro comemorava o passado. ${ }^{52}$

O ideal de modernidade levado a cabo por essa administração estava claro. A cidade, contudo, passava por um processo de modernização muito mais amplo e múltiplo. Cinemas, corridas de automóveis, a expansão do sistema de energia elétrica. A perspectiva oligárquica começaria a dar mais atenção à atividade industrial que vinha crescendo. "Essa aliança envolvia a adequação da capital a esse cenário alternativo e era a única saída para a crise de representação que se anunciava" ${ }^{53}$, o que significava uma renovação da infraestrutura que visava dar mais espaço às indústrias.

Apesar das reformas estruturais na cidade do Rio de Janeiro, que movimentava os signos da cidade letrada de acordo com os movimentos do 
poder $^{54}$, as crises que se anunciavam no interior das elites oligárquicas eram mais profundas, e mobilizavam outros signos e outros leitores desse discurso que se encaminhava para a saturação.

O pacto federativo que havia se instalado no decorrer da Primeira República e que, com o tempo, consolidou a hierarquia oligárquica já conhecida nos primeiros anos republicanos, dava primazia aos poderes provenientes dos estados de Minas Gerais e São Paulo, com participação por vezes do Rio Grande do Sul. Essas oligarquias rurais regionais compunham um núcleo de poder rodeado pelo que ficou conhecido como estados de segunda grandeza. Entre eles, Bahia, Pernambuco, Espírito Santo e Rio de Janeiro compunham forças aliadas ou oposicionistas adequadas ao jogo de poder estabelecido. Esse pacto, que começou a tomar forma com a política de Campos Sales ainda na virada do século, dava indícios de esgotar-se. Rui Barbosa, já em 1910 com a campanha civilista, acenava para um tipo de política à margem do sistema oligárquico. Em oposição à candidatura de Hermes da Fonseca, Rui Barbosa chamava a atenção para a crescente população urbana, em especial para o contexto industrial que, ainda que incipiente, se anunciava. Esse estilo de campanha oposicionista, com base no protesto e sem a articulação necessária com as elites, rendeu a ele três derrotas, em 1910, 1914 e 1919. No último ano, contudo, sua campanha baseada no protesto contra Epitácio Pessoa rendeu-lhe, sem qualquer apoio da máquina eleitoral, um terço dos votos, tendo vencido no Distrito Federal ${ }^{55}$.

Apesar das derrotas, as campanhas de Rui Barbosa abriram precedente. Quando em 1921 o eixo Minas - São Paulo lançou a candidatura do mineiro Artur Bernardes, em novo arranjo oligárquico, parte dos estados de segunda grandeza Bahia, Pernambuco e o estado do Rio de Janeiro - se aglutinaram ao redor do Rio Grande do Sul de Borges de Medeiros no que ficou conhecido como a Reação Republicana. Os receios do Sul e dos estados menores deviam-se a interesses opostos, segundo Boris Fausto, com relação à política de valorização do café, aliado ao temor das promessas de uma revisão constitucional - efetivamente realizada por Bernardes em 1926. Ainda segundo Fausto, a oposição, que se reuniu em torno da candidatura de Nilo Peçanha, optou por uma campanha "à americana", como se dizia, "percorrendo boa parte do país e procurando atrair o voto urbano" 56 . 
A campanha fazia referência à política econômica de Campos Sales, abandonada pelos governos seguintes, além de promover constantes ataques ao que chamava de imperialismo dos grandes estados. A Reação indicava uma ruptura, ou melhor, a tentativa de constituição de um eixo alternativo de poder dentro das oligarquias. Para além disso, o caráter urbano de mobilização popular indicava um futuro possível para a política, que nunca antes havia logrado êxito. Vinculado às agitações operárias, às greves de 1917 e a importância que vinha tomando a questão social, a campanha de Nilo Peçanha se revestiu de um apelo popular abordando questões como o conflito entre capital e trabalho.

A penetração do nome de Nilo junto às camadas urbanas do Distrito Federal pode ser explicada não só em função de suas características pessoais, pois era um excelente orador, com grande capacidade de comunicação, mas também pelas próprias características e anseios dos grupos republicanos. Numa sociedade em que esses segmentos se achavam marginalizados da participação política, o simples fato de o discurso nilista considerá-los como interlocutores dignos de atenção já era em si uma iniciativa mobilizadora. ${ }^{57}$

À crescente importância e presença da população e produção urbana no contexto político e econômico do país, a parte dissidente das elites oligárquicas não perdeu tempo em trazê-la para perto. O contexto de crescimento urbano e a sua preocupação pelas elites reproduzia o histórico processo de uniformização elitista que o obscurecimento das manifestações populares já presenciara no imaginário construído em torno das reformas urbanas da capital federal. A capital em trompe l'oeil $^{58}$ seus postulados a nível nacional, em termos políticos e culturais, na reordenação operada pelas elites.

É nesse sentido que o modernismo paulista irá negar completamente, como será visto adiante, um movimento literário que na capital ganhava forma e força em sintonia expressiva com o que Mônica Pimenta Velloso chama de "Cultura do Modernismo". O grupo dos boêmios, ligados à produção simbolista, "tinha como um dos principais instrumentos de comunicação a linguagem humorística”, e construía uma percepção da nacionalidade baseada na perspectiva do humor, da sátira e das caricaturas ${ }^{59}$. Ao reforço dos ideais aristocratizantes das classes políticas, o grupo dos boêmios contrapunham a troca com as classes e manifestações populares, "compartilhando o sentimento de rebeldia e exclusão social. Houve um forte intercâmbio cultural entre esses grupos, estabelecendo-se frequentemente parcerias musicais, no teatro de revista e no carnaval" ${ }^{60}$. Essa comunicação com as camadas populares, entre diversos segmentos sociais, 
redundou em férteis trocas culturais, que se apresentam como características da cultura do modernismo, ao melhor estilo definido por Baudelaire em " $\mathrm{O}$ pintor da vida moderna". Nesse contexto, o show de luzes da Semana de 1922 em São Paulo e os consequentes caminhos das elites brasileiras determinariam os rumos da arte, ditados pelas propostas que a nova geração da elite que marcou a posição de boa parte dos artistas modernistas ${ }^{61}$, sempre às voltas nas fronteiras entre a imitação europeia e a originalidade. Em 1925, Alceu tece críticas contundentes à poesia Pau-Brasil de Oswald de Andrade, acusando-o simultaneamente da imitação externa e da distância interna com a realidade nacional, os dois polos do manifesto Pau Brasil. Em crônica de junho de 1925, escreve sobre as afirmações de Oswald:

Apenas há um pequeno engano na frase enfática do sr. Oswald de Andrade. A sua poesia é tão importação quanto as demais. A única diferença é a seguinte: - é que ele importa mercadoria deteriorada, - automóveis em segunda mão, máquinas já usadas e enferrujadas, etc.

Toda a originalidade novinha em folha do sr. Oswald de Andrade, toda a sua literatura mandioca, aborígene, precrabálica, precolombiana, premongólica, toda ela é bebidinha, direta ou indiretamente, em duas fontes europeias muito recentes e muito conhecidas: o dadaismo francês e o expressionismo alemão. Para mencionar apenas os dois movimentos fixadores de um mal que já contaminou todos os paízes $(\ldots)^{62}$

A forma como essas movimentações das classes dirigentes tomam para si o dever de definir o que era o moderno, o urbano, o novo, o ultrapassado, o estrangeiro, o nacional, ganha expressão nas disputas oligárquicas a partir da Reação Republicana em 1921, que terá em 1922 o ano chave de construção dessa curadoria narrativa. A memória transformaria o abalo sísmico de 1922 em grande terremoto, ao passo que não se disporia a lembrar das movimentações tectônicas que o precederam. É nesse contexto que Alceu, alcunhado posteriormente de "o crítico do modernismo", exercerá enquanto crítico esse papel central no seio das novas elites, definindo seu lugar no campo intelectual enquanto define, legitima e rejeita, em última instância, ajuda a formar os contornos do próprio campo no qual buscava se firmar.

A Reação Republicana teve outra frente central nas disputas eleitorais daquele ano. Como não possuía a máquina do Estado que lhe conferisse força eleitoral, a campanha buscou aliar-se a extratos da sociedade que pudessem reforçar a oposição, e os militares eram o segmento ideal para isso. Egressos de inúmeros desentendimentos com o governo federal devido a tensões com relação a postos importantes na gestão de Epitácio Pessoa, os ânimos dos militares se 
haviam apaziguado com a volta de Hermes da Fonseca em 1920 e sua eleição para presidente do Clube Militar em 1921. A não concretização de sua candidatura à sucessão presidencial fez com que os militares ficassem insatisfeitos, e Nilo Peçanha - que havia apoiado a candidatura do marechal Hermes em 1910 - fez questão de reforçar o apoio do exército e da marinha à sua campanha ${ }^{63}$, durante a qual ficara clara a insatisfação dos militares, principalmente aqueles que tinham em Hermes da Fonseca uma figura de referência.

Ao longo da campanha foi reforçado o caráter antimilitar de Bernardes, como demonstra o episódio das cartas falsas. O Correio da Manhã publicou em outubro de 1921 cartas supostamente enviadas por Artur Bernardes a Raul Soares em que chamava Hermes da Fonseca de "sargento sem compostura", um "canalha [que] precisa de uma reprimenda para entrar na compostura" ${ }^{64}$. Tais cartas, que posteriormente seriam comprovadas como uma armação da campanha oposicionista, puseram lenha na fogueira. A vitória inevitavelmente foi para o candidato da situação, mas a essa altura, a tensão já havia subido significativamente. O Clube Militar lançou um protesto contra a utilização indevida de tropas em Pernambuco, e em reprimenda o governo federal decretou a prisão de Hermes da Fonseca e o fechamento do Clube Militar. A Reação Republicana não reconheceu a derrota e exigiu a criação de uma comissão que averiguasse o processo eleitoral, enquanto continuavam uma campanha "visando, de um lado, manter a mobilização popular e, de outro, aprofundar o processo de acirramento dos ânimos militares" ${ }^{65}$. A intransigência e indisposição do governo de abrir-se ao diálogo contribuiu para o aumento do clima de agitação política e começava a dar os primeiros sinais de levantes armados por parte do exército, no Distrito Federal e em Niterói. Esse processo duplo, de crescimento do espaço das camadas urbanas e de lançamento dos grupos militares ao campo político em crescente efervescência proporcionou o clima ideal para os levantes que dariam o pontapé inicial do tenentismo. Sobre a Reação, concluem Marieta Ferreira e Surama Pinto:

A Reação Republicana resultou da insatisfação das oligarquias de segunda grandeza ante a dominação de Minas e São Paulo. A resistência dos estados do Rio de Janeiro, Bahia, Pernambuco, Rio Grande do Sul e do Distrito Federal não era um fenômeno novo, pois em várias ocasiões pôde-se detectar uma busca de articulação entre essas oligarquias estaduais com o objetivo de aumentar seu poder de negociação ante os resultados dominantes. O movimento de 1922 foi um momento expressivo dessa luta. Não devem ser esquecidas, entretanto, as formas 
de articulação buscadas pelos integrantes da Reação Republicana com os setores urbanos, em especial do Distrito Federal, e com os militares. ${ }^{66}$

As mais diversas interpretações sobre o tenentismo ao longo da década de 1920, herdeiro direto das tensões que marcaram a crise das oligarquias no início da década, concordam quanto ao papel que ele teve no processo de erosão do sistema político vigente ${ }^{67}$. Mário Cleber Lanna Junior reafirma essa perspectiva ao afirmar que ele "fez parte da crise institucional da década de 1920, quando a política da Primeira República foi marcada pela violência e pela força" ${ }^{68}$. Para além das inúmeras interpretações que a historiografia construiu sobre o tema ao longo do século XX, é importante perceber que o movimento dos tenentes significou a percepção interna dos grupos militares de serem portadores de funções específicas dentro da estrutura do país, e por isso legítimos interventores na política nacional ${ }^{69}$.

A revolta dos 18 do Forte, ocorrida em Copacabana, na capital federal, transformou uma derrota militar em ícone que seria consolidado com o levante de 1924 em São Paulo e a posterior formação da coluna Miguel Costa-Prestes. A derrota da Reação Republicana tinha posto em xeque a possibilidade de ação política dentro dos moldes republicanos. Os grupos que se viam a margem das dinâmicas do poder cada vez mais percebiam a rigidez com que a política republicana se fechava. Por isso, sobre o tenentismo afirma Lanna Junior:

No período [de 1922 a 1927], surgiu como única alternativa dos anseios das classes médias populares. As mudanças tinham de ser feitas pelas armas, o que teria transformado os militares rebeldes em vanguarda política da luta contra o domínio oligárquico da burguesia cafeeira e seus aliados. ${ }^{70}$

Com um discurso moralizador, de regeneração, os revoltosos de Copacabana de julho de 1922 - que foram seguidos por tentativas de levantes em outros estados - à época traziam difusas reivindicações como a moralização do exército e a defesa da ordem. Rapidamente contida a revolta, dezessete militares e um civil saíram em marcha na orla de Copacabana, e um a um foram mortos pelas forças de contenção, sobrando como únicos sobreviventes os tenentes Siqueira Campos e Eduardo Gomes. A marcha contribuiu para que se criasse a legenda do "tenentismo" 71 . O simbolismo que se criou ao redor dos dezoito do Forte contribuiu para que uma articulação mais ampla começasse a tomar forma sob a bandeira do tenentismo. Dois anos depois, também em julho, a cidade de São Paulo foi surpreendentemente tomada por um levante de militares. À surpresa da vitória foi seguido o assombro da repressão. 
Expulsas da cidade, as forças políticas de repressão começariam um bombardeio constante e violento contra a própria população. Aviões bombardeavam a cidade tomada pelos tenentes sem nenhuma preocupação com a segurança dos moradores. O governador Carlos de Campos, instalado nos arredores da cidade, ordenava o ataque constante durante o sítio da capital paulista. Com a falta de gêneros alimentícios ameaçando uma crise e os inúmeros ataques inescrupulosos das forças do Estado, os tenentes, sob comando do general Isidoro, estavam diante de um dilema. A responsabilidade pela segurança da população impunha a retirada da cidade, mesmo que essa significasse a derrota do levante. No dia 27, foi isso que fizeram. Os tenentes se retiraram de São Paulo em função do perigo da população civil, que saíra em sua defesa, acuada pela truculência do governo. $\mathrm{O}$ evento foi crucial para o acirramento da crise de legitimidade do poder instaurado, acusado de atacar o próprio povo, ao passo que contribuiu para a construção do imaginário sobre os tenentes como a força revolucionária que poderia proporcionar a saída para a crise no país. A formação, em consequência desse episódio, da coluna Miguel Costa - Prestes manteria essa lenda viva até 1927, quando a coluna foi desfeita e muitos de seus membros se exilaram em países vizinhos, sem contudo esvaziar o lugar simbólico que ocupavam como força alternativa nacional. $\mathrm{O}$ imaginário tenentista seria mobilizado novamente no contexto da movimentação revolucionária de 1930 que o usaria como moeda de legitimação do levante.

As movimentações políticas, sociais e culturais surgiam e se organizavam ao passo que a crise do modelo oligárquico ia se aguçando. As dimensões do fim e do novo ganhavam espaço na crescente tensão que acompanhava os reordenamentos estruturais da sociedade brasileira ao fim da Primeira República. Em 1926, a cisão interna da oligarquia paulista - já a voltas com o imaginário tenentista no campo político, com as organizações trabalhadoras e o BOC no campo social e com um modernismo mais agressivo e combativo o campo cultural - daria origem ao Partido Democrático (PD) em São Paulo. Representando a camada dissidente das elites e associado aos novos movimentos intelectuais paulistas, o PD trazia propostas liberais que o PRP, durante tantos anos no poder, havia deixado de lado, e se organizava ao redor de nomes como o conselheiro Antônio Prado - pai de Paulo Prado, um dos grandes patrocinadores da Semana de 1922 e dos primeiros artistas modernistas - e Mário de Andrade $^{72}$. Esses três 
campos - político, social e cultural - se entrelaçavam nas tramas simbólicas de um imaginário abalado pela sedução do novo que a modernidade constantemente punha em jogo. As dinâmicas com que os dispositivos discursivos criavam novas possibilidades de ação se associavam às narrativas que eram construídas concomitantemente aos acontecimentos.

Em 1928 a percepção de esgotamento era incontornável, e a mobilização se mostrava como condição de sobrevivência. O relativamente tranquilo governo de Washington Luís, que a princípio aparentava ter contornado os confrontos que marcaram o início da década ${ }^{73}$, guardava uma tensão latente que esperava as próximas eleições para vir à tona. Por mais que as forças dissidentes não oferecessem confronto direto com o governo estabelecido, a dimensão da mobilização havia tomado conta do imaginário corrente. "Nesse final de década, afirma Sevcenko - os tempos se tornaram convulsos e as mentes se turvaram. $\mathrm{O}$ acirramento das militâncias queria ver em cada criatura, um soldado, numa guerra que só admitia dois lados, o certo e o errado, o justo e o opressivo, o bem e o mal" 74.

Chegando o período de sua sucessão, o presidente, quebrando o acordo tácito com o partido mineiro, tenta impor a candidatura de Júlio Prestes para ocupar a posição de seu sucessor. O estado, por isso, viria a apoiar a candidatura de oposição, o então governador gaúcho Getúlio Vargas, ex-ministro da Fazenda de Washington Luís.

Estava formada a Aliança Liberal, uma coligação de forças políticas e partidárias pró-Vargas. Sua base de sustentação era o situacionismo de Minas Gerais, Rio Grande do Sul e Paraíba, e mais alguns grupos de oposição ao governo de vários estados, tais como o Partido Democrático (PD), criado em 1926 em São Paulo, e facções civis e militares descontentes. Com uma composição cuja característica mais pronunciada era a heterogeneidade, a Aliança Liberal explicitava as dissidências existentes no interior das próprias oligarquias estaduais. ${ }^{75}$

A campanha da Aliança Liberal seguiu, em parte, os moldes estabelecidos pelas dissidências do passado, no caráter urbano e mobilizador que já haviam buscado Rui Barbosa e Nilo Peçanha. Ao chegar em São Paulo, a mobilização popular em torno da marcha de Getúlio surpreendeu os próprios participantes da campanha. Passadas as votações, a derrota sofrida não foi aceita pela Aliança, que acreditava em sua vitória em função do apelo popular que tinha. Acusando o governo de forjar as eleições, manteve a mobilização em torno de suas pautas e da 
contestação ao resultado das urnas. Começavam as movimentações revolucionárias.

A aliança buscaria se aproximar de lideranças como as do movimento tenentista. A congregação de forças oposicionistas tomava corpo em uma revolução que se anunciava de forma vaga desde 1928. Os caminhos da Revolução de 1930 e a instauração do governo provisório instauraram uma dupla disputa que abrindo-se à ação no presente, estendia os dois braços, um em direção ao passado, outro ao futuro, como a eloquente figura do Cristo Redentor inaugurada no ano seguinte. É nesse sentido que nesse momento crucial, a disputa pelos rumos da revolução que caracterizaram os primeiros anos de governo - em especial nos debates em torno da constituinte de 1933 - se coaduna com a construção da linearidade narrativa que justificava os caminhos da revolução pelo que havia levado a ela, e que buscava instaurar definitivamente o sujeito político que caracterizaria os "revolucionários" ${ }^{76}$. Operando nessa mesma lógica, Alceu afirmará em texto n'A Ordem em outubro de 1930, no qual lançava uma palavra de apoio e orientação ao grupo católico que a revista congregava, que "se a República brasileira se afoga hoje em sangue é que esqueceu por quarenta anos essa norma fundamental da vida de um povo, como da vida de um homem". A esse aceno ao passado, nesse caso na chave da ausência, completa enfatizando: "Contra a Autoridade sem Deus, como contra a Revolução Sanguinária, nosso dever é lutar com as armas da oração, da doutrina, da organização, do exemplo moral" ${ }^{77}$. A articulação entre a interpretação que se faz da revolução e as indicações de como agir são claras:

a Revolução que aí temos desencadeada não é obra dos governos nefastos nem das oposições extremadas. Ela é obra da constituição sem Deus, da escola sem Deus, da família sem Deus, das consciências sem Deus. Restituir a lei de Deus, de Cristo e da Igreja, à constituição, à escola, à família e às consciências, eis o caminho único da paz. ${ }^{78}$

Evidentemente, a voz de Alceu não era única, muito menos estava isolada. Sua conversão, mostrando a disposição para a mobilização que tomava conta da época, o fez aliar-se a um conjunto de forças que há tempos vinha atuando junto à sociedade civil. Desde o início do século setores da Igreja, diante de processos de mudança, sublinhavam a necessidade da Igreja atualizar o seu lugar na sociedade como corpo atuante, retomando espaços que havia perdido ou que precisaria conquistar. Essa nova postura, que ficou conhecida como a Restauração Católica, tomou fôlego a partir da transferência do bispo de Olinda e Recife, Dom Sebastião 
Leme, para o Rio de Janeiro, na condição de bispo coadjutor do cardeal Joaquim Arcoverde. Esse processo, no qual Amoroso Lima se insere em uma fase crucial, já vinha se expandindo no momento em que ele tomou para si a posição de liderança dos leigos católicos. Esses caminhos da Igreja, que relacionando-se com os acontecimentos buscava firmar o seu lugar, é de extrema importância para se entender a conversão do crítico literário.

\subsection{A Restauração Católica}

O início do século XX viria a redefinir a forma como a Igreja Católica se relacionava com a sociedade, tanto no nível do poder administrativo como no que se refere à sua ação na sociedade. A modernidade que trazia ares novos, que anunciava profundas e estruturais mudanças, colocou em questão o lugar tradicional por ela ocupado, pôs novos agentes em jogo, ressignificou signos, discursos e espaços, e se dispôs a acabar com o que considerava ser o velho mundo, propondo novos aromas e novos sabores. Se em 1870 alguns acontecimentos já podem indicar as transformações políticas, econômicas e sociais em curso, pode-se dizer que a partir da Proclamação da República em 1889, com a separação entre Igreja e Estado e a adoção de ideais liberais e positivistas por grupos governantes, essas mudanças começariam a ser intensamente percebidas, pelo menos no que se refere ao lugar da Igreja na nação tropical que dava novos primeiros passos. Se no campo intelectual a geração de 1870 já apontava para uma modernização da literatura e se formava um grupo oposicionista em torno da publicação do Manifesto Republicano, a década também significou para a Igreja a indicação de que o modelo do padroado que marcara as relações entre Igreja e Estado estava se esgotando. A Questão Religiosa que envolveu o bispo de Olinda Dom Vital Maria e o bispo de Belem, D. Antonio de Macedo Costa, ao ir contra uma deliberação imperial. Naquele momento, o Imperador tinha, conforme acordos do padroado, o privilégio de fazer com que decisões da Santa Sé só fossem vigentes dentro do território nacional mediante sua prévia aprovação o que equivalia a submeter as decisões papais ao "cumpra-se" do imperador. Quando Pio IX escreve uma bula pontifícia com a condenação da maçonaria e a proibição de que seus membros frequentem os sacramentos, o documento não recebe o "placet" do imperador, mas os dois bispos decidem fazer cumprir a deliberação da Santa Sé em suas dioceses. O episódio levaria à prisão dos bispos, porém marcaria na memória da Igreja Católica um 
momento, segundo a interpretação do Padre Julio Maria, missionário belga romanizado atuante no Brasil, de libertação do jugo mundano sobre os assuntos vistos como sagrados. A memória de Dom Vital seria consolidada posteriormente nas palavras do padre Júlio Maria como um grito de liberdade para a Igreja ${ }^{79}$. E o bispo de Olinda seria homenageado anos depois na fundação do Centro Dom Vital.

A perspectiva da perda, na constituição de 1891, da posição que a Igreja ocupava de liberdade, na colônia, e de união com o Estado no império afetou profundamente não somente sua influência nas altas decisões de Estado, como a deixou à sua própria sorte em termos de manutenção, desenvolvimento e influência. Dando fim a anos de história do padroado, a separação entre a Igreja Católica e o Estado brasileiro, advinda dos ideais liberais que defendiam um Estado laico, reverbera intensamente não apenas no interior desta, mas, a longo prazo, no próprio sentido do que é a catolicidade brasileira.

Os anos que se seguem à Constituição de 1891 são um período de redefinições para a hierarquia católica que não estava preparada ou estruturada para constituir-se em um agente político autônomo, deslocada das instâncias administrativas oficiais. A Igreja corria o risco de perder sua força e influência frente às questões nacionais de cunho político ou social que marcaram sua história. Tania Salem afirma que "os dois primeiros decênios do regime republicano são caracterizados pela letargia e passividade nos meios católicos brasileiros" ${ }^{80}$. Dom Sebastião Leme, em sua Carta Pastoral de 1916, ao tomar posse como arcebispo de Olinda, chama a atenção para o "marasmo atrofiante" no qual se encontravam os meios católicos após a proclamação da República:

Na verdade, os católicos, somos a maioria do Brasil e, no entanto, católicos não são os princípios e os órgãos da nossa vida política. Não é católica a lei que nos rege. Da nossa fé prescindem os depositários da autoridade. Leigas são as nossas escolas; leigo o ensino.

E conclui:

Sim, ao católico não pode ser indiferente que a sua pátria seja ou não aliada de Jesus Cristo. Seria trair a pátria! Eis por que, com todas as energias de nossa alma de católicos brasileiros, urge rompamos com o marasmo atrofiante com que nos habituamos a ser uma maioria nominal, esquecida dos seus deveres, sem consciência dos seus direitos. É grande o mal, urgente é a cura. Tentá-lo - é obra de fé e ato de patriotismo. ${ }^{81}$

A carta pastoral de Dom Leme é tida por muitos como o escrito fundacional do que viria a ser a restauração católica no Brasil. Nela, o então novo arcebispo de Olinda elabora as bases do movimento restaurador que tomaria força alguns anos 
depois, principalmente após a sua mudança para o Rio, quando nomeado bispo coadjutor do Cardeal Arcoverde. Esse manifesto, contudo, apesar de ganhar com o tempo o lugar de ponto fundacional da Restauração - em parte pela continuada ação central de Dom Leme por muitos anos - se aproxima das denúncias que o padre Júlio Maria, já nas décadas de 1890 e 1900 fazia. O Padre entendia o período republicano como um período de possibilidades, em que a aproximação entre Igreja e povo se tornaria central se o catolicismo pretendesse, em suas palavras, fazer retornar as almas, por tanto tempo perdidas, à verdadeira doutrina de Cristo. Voz importante, mas isolada, Júlio Maria não viu, em seu tempo, suas palavras tornarem-se ação efetiva. Da mesma forma, a carta pastoral de Dom Leme, apesar de central e de ser um chamado para ação, ainda surgia em um contexto de pouca mobilização.

É a partir da vinda do bispo para o Rio de Janeiro em 1921 que as dinâmicas de organização realmente começam e tomar forma, principalmente através de suas celebrações e articulações políticas, de um lado e por outro, da organização dos leigos e em especial dos intelectuais em torno da revista $A$ Ordem e do Centro Dom Vital, com a liderança de nomes como os de Jackson de Figueiredo e Hamilton Nogueira. Contudo, ela prenuncia, entre outras coisas, a importância dos intelectuais enquanto agentes em prol dos objetivos da Igreja, que professa a concordância entre ciência e fé e, como Antonio Carlos Villaça chega a afirmar: "é uma pastoral toda voltada a um tempo para a inteligência e para a ação" 82 .

O distanciamento em relação ao Estado, por outro lado, deu à Igreja uma liberdade nunca antes experimentada pela instituição no Brasil no período do Estado Imperial. Sobre a separação entre Igreja e Estado definida pela constituição republicana, é lançada uma pastoral coletiva, assinada por todos os bispos, que reconhecia que

se no decreto há cláusulas que podem facilmente abrir a porta a restrições odiosas desta liberdade (a eclesiástica), é preciso reconhecer que, tal qual está redigido, o decreto assegura à Igreja Católica do Brasil uma certa soma de liberdade que ela jamais logrou no tempo da monarquia. ${ }^{83}$

Se por um lado a Igreja não estava mais diretamente ligada ao Estado, este também não tinha mais jurisdição alguma acerca das decisões eclesiásticas como outrora, e ela se viu livre das restrições que eram impostas pelo poder imperial. As duas primeiras décadas da República são, por esse motivo, marcadas por um intenso aumento do número de ordens religiosas, que com a queda do padroado e 
o processo de romanização da Igreja puderam se instalar de forma mais autônoma em território brasileiro. O país abriu-se, por iniciativa da hierarquia católica, a essas diversas ordens religiosas, vindas principalmente da Europa. É neste momento que o ensino religioso nas escolas ganha corpo no Brasil. $\mathrm{O}$ aumento dos institutos religiosos masculinos e femininos é expressivo. Hospitais e colégios católicos são as principais contribuições de tais institutos que permitiam a instalação consistente destas novas ordens em território nacional.

Esta situação inicial, ao longo das primeiras décadas da República, abrirá espaço para uma série de tensões entre os governos e os grupos religiosos. Com a falta de auxílio vinda do Estado, a Igreja estreitará seus laços com a Santa Sé. Acerca desse período, o historiador José Oscar Beozzo afirma:

Do mesmo modo que as elites dirigentes do país se subordinam às ideologias dominantes na Europa e nos Estados Unidos, ao liberalismo, ao positivismo, a Igreja vai seguir um caminho paralelo, na sua reforma. Se as elites tornam-se "estrangeiras" na sua cultura, também a Igreja, fazendo vir da Europa uma centena e meia de congregações e ordens religiosas masculinas e femininas, num curto período de trinta anos, vai se europeizar e romanizar, tornando-se estranha à religião luso-brasileira, até então praticada pelo povo e veiculada pela Igreja. ${ }^{84}$

Isso se expressa, entre outros aspectos, pelo aumento considerável do número de bispados e arcebispados do país: se em 1850 havia no Brasil nove dioceses e uma arquidiocese, em 1930 esses números já ultrapassam 60 dioceses e quase 10 arquidioceses ${ }^{85}$.

O pensamento romanista, fruto de uma ligação direta com o Vaticano através das diversas instituições religiosas que se proliferam a partir desse momento, ganha também força devido a esta aproximação com a Santa Sé. Afirma Maurício de Aquino:

Num encontro de interesses e necessidades a Igreja do Brasil se alinhou definitivamente às estruturas administrativas da Sé Romana. Para o Vaticano era fundamental contar com a fidelidade da significativa Igreja do Brasil às diretrizes romanas, para a hierarquia eclesiástica brasileira era imprescindível o apoio, o modelo e o capital simbólico da Sé Romana, considerada sede espiritual e institucional do catolicismo. ${ }^{86}$

O ideal romanista, devido a esse estreitamento de relações, se difunde ainda mais em território brasileiro como forma supostamente mais eficiente de manutenção da Igreja. Herdeiros do pensamento ultramontano, como afirma Riolando $\mathrm{Azzi}^{87}$, os romanistas viam na Igreja uma instituição por definição internacional e por isso acreditavam na ligação direta de suas ramificações com Roma, através de instituições que se reportassem ao vaticano. O crescimento do 
número de ordens independentes que os primeiros anos da República possibilitaram foi terreno fértil para tais ideias.

O núcleo central desse pensamento gira ao redor da instituição eclesiástica, que deve ser prestigiada e fortalecida de modo absoluto, sem aceitação de qualquer tipo de crítica. Portadora dos meios de salvação, essa Igreja hierarquizada e comandada pela Santa Sé continua a constituir um bastião da ordem social conservadora, opondo-se tenazmente a todos os movimentos de caráter político, econômico ou social que apresentem projetos de alterações significativas nas estruturas vigentes. ${ }^{88}$

Esse pensamento, que suprime o caráter nacional da Igreja e ressalta sua dimensão universal, acabou por ser articulado por um episcopado que, apesar de em sua maioria romanista, era sensível à realidade brasileira e à suposta necessidade de intervenção por meio da moral católica. A defesa da hierarquia tanto eclesiástica quanto política-, da autoridade e da ordem estavam no cerne do pensamento católico e de seu itinerário no início do século.

Outra característica marcante do pensamento romanista é a diferenciação entre, segundo este pensamento, os verdadeiros católicos, praticantes, e aqueles que o são apenas por tradição. A partir desta diferenciação, como ressalta Azzi, os "católicos praticantes passam a constituir a ponta de lança da Igreja, a fim de exigir do Estado o reconhecimento dos direitos que a hierarquia eclesiástica pretende reivindicar para a sua atuação mais completa na sociedade brasileira" ${ }^{89}$. Estes católicos praticantes seriam aqueles à frente da luta pela moral e pelos ideais católicos, tanto na educação e nos meios intelectuais, quanto no mundo do trabalho, através dos círculos operários.

A partir daí, dá-se o início da mudança de posição da Igreja frente ao mundo que viria a ser chamada de Restauração Católica. Segundo afirma Azzi, "a Igreja passa de uma posição declaradamente defensiva, típica da mentalidade do século XIX, para uma nova atitude de conquista espiritual do mundo" ${ }^{90}$. O esforço do clero a partir dos anos 1920 será dirigido à busca de uma relação com o Estado não mais de vinculação direta, mas de colaboração mútua.

Assim como é importante ressaltar as peculiaridades dos rumos que a Igreja tomou no Brasil neste período, é imprescindível destacar como esta realidade era presente a nível internacional. Desde a Revolução Francesa, o catolicismo vinha perdendo gradualmente sua influência, outrora hegemônica em países de tradição cristã, no cenário político e social, devido ao avanço de ideias liberais e laicizantes. Se no Brasil tem-se a carta pastoral de Dom Leme como ato fundador, 
pode-se dizer que a encíclica Rerum Novarum carrega essa dimensão no cenário internacional. Nela, o papa Leão XIII dá as bases do que viria a ser a Doutrina Social da Igreja, cerne formador do pensamento católico e sua atuação no Estado e na sociedade até pelo menos as décadas de 1940 e 1950. Nela, o sumo pontífice se posta frente às coisas novas que trazia a modernidade, e discorre sobre as errôneas tentativas de solução propostas. Quarenta anos depois, em 1931, o papa Pio XI, que tinha como lema de seu pontificado "restaurar todas as coisas em Cristo" 91, escreve a encíclica denominada Quadragesimo Anno, propondo atualizar, em face dos novos contextos que se revelavam, as propostas de Leão XIII. O autor Carlos André Silva de Moura afirma que:

Desde os escritos de Leão XIII, as cartas pastorais, encíclicas e bulas papais passaram a orientar os religiosos para a sacralização da política e para a mudança de postura dos eclesiásticos em relação aos movimentos sociais, abandonando a posição defensiva da Igreja Católica para ações mais ofensivas. Os documentos destacaram a importância do clero nos debates políticos e demonstraram os 'perigos' de uma nação laica. ${ }^{92}$

Isso é visto, com efeito, nos escritos de Antonio Gramsci sobre a Igreja, em que percebe a mesma na modernidade como um ator - dentre muitos - no cenário político e intelectual: “A Ação Católica assinala o início de uma época nova na história da religião católica: quando ela, de concepção totalitária, torna-se parcial e deve possuir um partido próprio" ${ }^{93}$. Gramsci analisa a aproximação entre a Igreja e o governo fascista que sobe ao poder na Itália no início do século XX, e como esta, vendo-se deslocada do poder e atuando como mais um grupo ideológico, busca atuação mais profunda na sociedade por meio da militância católica e da atuação de seus agentes - tanto bispos e padres quanto intelectuais e literatos - nas questões nacionais.

O termo "Restauração" é tema de uma das encíclicas do Papa Pio X, que afirma: "Proclamamos que Nós não temos nenhum outro programa no Supremo Pontificado, que não o 'de restaurar todas as coisas em Cristo' (Ef. I., 10), de modo que 'Cristo seja tudo em todos' (Coloss. III, 2) " ${ }^{94}$, e se torna lema do pontificado de Pio XI, a partir da década de 1920.

Acerca do termo "restauração", Azzi afirma:

É necessário precisar bem o significado do termo "restauração". [...] trata-se, em primeiro lugar, de dar ao objeto um aspecto novo, uma nova apresentação em vista do desgaste do tempo; em segundo lugar, essa nova face deve ser moldada pelo seu aspecto primitivo. [...] O termo "Restauração Católica" tem um sentido análogo. Não se trata de introduzir novas perspectivas ou novas orientações na vida da 
Igreja, mas fundamentalmente em reconduzir a instituição eclesiástica a um modelo antigo. ${ }^{95}$

Através de uma remodelação na forma como atuam na sociedade e em sua posição perante as classes dirigentes, os católicos irão agir para que "a fé católica volte a ser um dos elementos constitutivos da sociedade" ${ }^{96}$. O clero busca a restauração da cristandade que teria sido perdida na modernidade. Esta cristandade, porém, não pode ser a mesma de outros tempos. Frente ao mundo moderno, a Igreja precisa reformular seus paradigmas e atuar de forma a constituir uma nova cristandade através da moralização e da hierarquia. A Igreja Católica, termo que nesse momento se restringia à hierarquia eclesiástica, não estaria mais atrelada diretamente ao Estado, mas constituir-se-ia um regime de mútua colaboração entre ela e o poder vigente. Buscava-se, como defende Azzi, uma "neocristandade" ${ }^{97}$, na qual a ordem seria retomada através da comunhão em Cristo e as forças liberais seriam derrotadas.

Durante a década de 1920, Dom Leme empreendeu um esforço enorme de aproximação da hierarquia eclesiástica com o Estado. Os governos da fase final da Primeira República tiveram na Igreja - principalmente na figura carismática do arcebispo - uma aliada na legitimação de suas políticas e de suas instituições junto à população. Em 1924, em banquete no Itamarati em comemoração ao jubileu do cardeal Arcoverde, é explicitada a vontade do governo federal e do presidente Arthur Bernardes de manter relações de reciprocidade com o clero católico $^{98}$. Em decorrência da crise e dos abalos sofridos pela Primeira República nos governos Arthur Bernardes e Washington Luís, a aproximação com o clero se manifesta numa busca legitimação e reafirmação de autoridade. Nesse sentido, Guilherme Arduini, em seu livro "Em Busca da Idade Nova", afirma que "mais que um processo de crise e de perda de influência, a Primeira República significou para a Igreja um momento de reconstrução" 99 .

Ao reivindicar o espírito católico nas questões nacionais e criticar o afastamento da nação em relação aos ideais católicos, Dom Leme e Jackson de Figueiredo trazem à luz dois aspectos principais desse momento de reconstrução. O primeiro é a mudança significativa do lugar de atuação da Igreja Católica em relação ao século anterior, que passa a assumir uma posição de atuação e militância numa sociedade, segundo Dom Leme em sua carta pastoral, cada vez mais afastada dos ideais cristãos. Em segundo lugar, esta alteração do lugar de 
atuação da Igreja significa uma mudança expressiva no que é a identidade da própria Igreja Católica.

As tensões deste período se mostravam favoráveis à penetração cada vez mais marcante da ideologia católica nas classes dirigentes ${ }^{100}$. Criado para angariar fundos para a revista $A$ Ordem, o Centro Dom Vital é expressão de uma intelectualidade católica incipiente. Além dele, no mesmo ano é fundada a Confederação Católica, que pretendia ser "um órgão coordenador e dinamizador do apostolado leigo" 101, e o Congresso Eucarístico do Rio de Janeiro, em 1922, que promove inúmeras missas campais, adorações públicas e procissões, e que recolhe as assinaturas para que fosse erguido, no coração da capital brasileira, o monumento ao Cristo Redentor, que ficaria pronto apenas nove anos mais tarde. $\mathrm{O}$ congresso foi uma expressiva demonstração da força social da religião católica ${ }^{102}$, e a construção do monumento, autorizada pelo Governo Federal, foi um inédito ato de força e de expressivo valor simbólico. Guilherme Arduini, ao comentar o trabalho de Romualdo Dias, ressalta: "Dias expõe ainda como o poder simbólico dessas ocasiões não pode ser negligenciado e complementa a formação doutrinária realizada pelos intelectuais católicos" ${ }^{103}$. É importante entender estes atos de valor simbólico e discurso imagético como expressão da força no empreendimento católico de doutrinação. Como será visto mais adiante, paralelo aos discursos intelectuais, e os permeando, os discursos simbólicos, como aquele que o Cristo Redentor entoa do alto do Corcovado, ou o das missas campais e festividades religiosas, que penetrando nos recônditos da vida e do quotidiano levam ao cidadão comum o discurso da Igreja, são de capital importância para se entender as aspirações e a base de pensamento do grupo católico naquele momento.

Ao longo da década de 1920 inúmeros eventos e ações do episcopado irão marcar a atuação do grupo católico na sociedade. Eventos organizados por Dom Leme como a Páscoa dos Militares, a Semana do Catolicismo e a Semana Missionária foram os meios pelos quais a Igreja, paulatinamente, mostrou sua força e presença no âmbito social. Ao passo da crescente visibilidade eclesiástica e proximidade de seu líder mais expressivo com o governo federal, a intelectualidade católica tomava forma a partir do Centro Dom Vital dirigido por Figueiredo que, no entanto, morreria súbita e precocemente em 1928. 
$\mathrm{Na}$ virada da década de 1930 a era Vargas começava e o clero, em consonância com as diretrizes eclesiais, mostraria sua força. A atuação do catolicismo na nova década se mostraria muito mais profunda e marcante na sociedade. O ideal hierárquico da Igreja se vê acolhido no caráter cada vez mais autoritário e centralizador do governo de Getúlio, chegando ao ápice da aproximação entre igreja e Estado no Estado Novo. Além do mais, a Era Vargas é marcada pela ascensão acentuada de uma burguesia industrial urbana, na qual não só a Igreja e o laicato militante tinham presença marcante, mas que também era o berço de uma nova intelectualidade que se formava. A intensificação da presença desta burguesia urbana pode indicar o importante papel que as dinâmicas ocorridas no Rio de Janeiro ocupavam na resolução das questões nacionais.

As inúmeras reivindicações no campo da organização social e operária se opunham a um pensamento considerado materialista que levava, por um lado, ao liberalismo burguês, e por outro, como sua contrapartida mais radical, ao socialismo. Defendendo a hierarquia, a ordem e a presença da religião católica como base constituinte da vida social brasileira, o grupo católico acabou por se aproximar de forma pragmática, na década de 1930, dos integralistas, o que é possível perceber a partir de inúmeros intelectuais e clérigos católicos que foram ligados ao Integralismo, como era o caso do então pe. Helder Pessoa Câmara, no Ceará. No Manifesto de Outubro, Plínio Salgado lança as bases da Ação Integralista Brasileira (AIB), que tinha forte influência dos movimentos fascistas europeus, principalmente de sua vertente italiana, que apelava pela reestruturação do mundo do trabalho e sua aproximação com o papado, assunto que é estudado, dentre outros, por Antonio Gramsci.

Pode-se constatar, no integralismo de Plínio Salgado, a intenção de aproximação com a Igreja, assim como no fascismo de Mussolini. Porém, na década de 1940, com o surgimento de novas ideias, em especial o humanismo integral de Jacques Maritain, o integralismo será negado por parte dessa intelectualidade católica como uma falsa apropriação e deturpação do nome de Deus para fins políticos e a construção de uma sociedade fora dos moldes da doutrina social da Igreja. A passagem da década de 1940 para 1950 será marcada, poder-se-ia dizer, por uma cisão no pensamento católico, que levará parte dos que até então defendiam de forma intransigente os princípios da autoridade social e política a tomarem uma inflexão em outra direção. O pensamento de Jacques 
Maritain e Yves Congar teriam influenciado esse grupo, incluindo Amoroso Lima, a direcionarem-se rumo a um caminho identificado com a democracia cristã, formando o que seria depois conhecido como a ala de esquerda da Igreja.

Esse processo dos anos 1950 irá ter forte influência posterior no que seria a primeira construção da memória desse movimento da Igreja. A força da figura do Alceu Amoroso Lima dos anos de repressão militar influenciaram de forma impactante a imagem da mudança que Alceu confere ao movimento católico, que será mais bem elaborada no próximo capítulo. O primeiro momento de construção dessa memória, basta dizer, foi expresso nas palavras de Antonio Carlos Villaça: "Se Jackson era um homem da vertente da autoridade, Alceu Amoroso Lima era da vertente da liberdade" 104. Essa afirmação, claro, é insuficiente. Ao se converter, Alceu assumira em grande parte a posição de seu mestre, e por mais que operasse uma virada cultural nos rumos da revista $A$ Ordem, o Alceu da liberdade e dos direitos civis que se conhecerá nas décadas finais de sua vida, fruto das mudanças na sociedade brasileira e na Igreja com o Concílio Vaticano II ainda estava longe de tomar forma.

\subsection{Tempos de tradição e ação}

É nesse sentido que entendo a conversão e a atuação de Alceu Amoroso Lima quando arregimentado pelas fileiras militantes do laicato intelectual de Dom Sebastião Leme. É em uma sociedade brasileira que se encontrava em um longo processo de mudança, gradualmente radicalizada que iria das mudanças técnicas e sociais à sublevação política. É nesse contexto moderno de industrialização e urbanização e diálogo com as tendências internacionais do pós-guerra que a restauração católica tomará a forma de uma religiosidade baseada na mobilização. Essa mobilização, que como já afirmei tem nos dois últimos anos da Primeira República o seu ápice - e que se num primeiro momento é um processo prioritariamente no campo simbólico, ao longo da década se associa ao processo de crise oligárquica e da economia cafeeira -, toma no imaginário coletivo a forma da ação como novo meio de relacionamento com o mundo. Como Nicolau Sevcenko tão elegantemente percebeu nos anos que precederam a explosão modernista: "Posta a ação como o âmago irradiador das significações na nova sociedade em formação, a herança cultural haurida dos séculos passados se torna obsoleta, ou só se mantém em circulação com sua carga de prestígio, se reelaborada em termos do novo código" ${ }^{105}$. Ao analisar o processo de mudanças 
da cultura urbana paulista dos anos 1920, percebe no surto metropolitano, associado às expansões tecnológicas e o fim de certas idealizações provindo do fim da Grande Guerra, essa mudança da mentalidade que ganhava uma aceleração inédita. Bem se sabe que as inovações tecnológicas há muito tempo vinham influenciando uma mudança estética ${ }^{106}$, mas Sevcenko chama atenção para a aceleração que essas dimensões tomaram nesses anos posteriores à Guerra.

Essa modernidade nova, que vinha com avassaladora violência do outro lado do oceano com seus signos e homens e bandeiras e estéticas de um ocidente que depois de 1914 não se reconhecia mais, viu terreno fértil nas metrópoles aqui em formação. Por isso creio que o percebido em São Paulo nesses anos de 1919 em diante podem ser de certa forma compreendidos também quando se analisa a realidade carioca da mesma época. Tal modernidade "evoca o primado do físico pelo espiritual, do aqui e do agora, sobre o lá e o após, do holístico sobre o heurístico, das forças inexoráveis sobre o indivíduo e o livre arbítrio, da ação sobre o pensamento, do instinto sobre a consciência" ${ }^{107}$.

A dimensão da ação tomaria forma de uma "mobilização permanente". As forças coletivas inexoráveis eram sentidas como o verdadeiro sentido da modernidade, que avassaladoramente impunha seus padrões. Junto com o crescimento editorial paulista ligado à expansão urbana, o surto do esporte em sua dimensão simbólica ganha contornos do maquinismo tecnicista vindo de rebarba nesse processo. A malha simbólica ligada à expansão expressiva do esporte tem no corpo e na representação da vitalidade sua centralidade - a associação com simbolismos clássicos do herói e do corpo atlético se relacionam com a ideia de uma ação racionalizada que leva a uma compreensão ulterior. Não é à toa que Antonio Alcantara Machado, desportista em seus anos de formação, fixa o foco na ação como elemento gerador estético.

Em carta a Amoroso Lima, em janeiro de 1931, ele afirma que "o dever do brasileiro neste momento se resume a isso: ação" ${ }^{108}$. Em dezembro do mesmo ano ele expressa a Alceu o seu desejo de que uma literatura modernista possa "acabar com a literatice burguesa (...). Sobretudo porque ela é inútil. Literatura sim: mas de ação" ${ }^{109}$. Passada a década de 1920, o que Sevcenko identificou como um imaginário difuso e subentendido na mudança de mentalidade se transformara, em muitas formas, em uma necessidade não só literária, mas política. 
Essa dimensão nova da ação e da mobilização propiciada em especial - mas não exclusivamente - pela guerra e pelo esporte promoveria antes de tudo uma negociação reformulada com a tradição. Aparentemente negando o passado e instaurando o radicalmente novo, a modernidade tecnológica convergia aspectos culturais na modernidade dissolvente que anunciava. Por isso as convergências entre a tecnologia inovadora do cinema e estratos culturais imemoriais, como a apropriação pelo esporte da valorização do físico atlético e do imaginário do herói grego, não tornavam menos radicais tais mudanças.

Uma vez mais, a mais revolucionária tecnologia se cruza e se ajusta circunstanciadamente com os legados simbólicos mais arcaicos - o que pode ser visível para um observador que surpreende as duas correntes paradoxais no limiar da sua intersecção, como para esse nosso cronista, mas não o será mais para as gerações que as recebem fundidas e as assimilam como um dado constituinte, permanente e banal da realidade cotidiana. ${ }^{110}$

Essa dimensão da relação entre a reformulação da tradição em termos modernos de mobilização trará dois gêneros dos mais consagrados para o centro da luta modernista de quebra com o passado: a escultura e a poética. Uma febre de monumentos e estátuas toma forma nesses anos em São Paulo, que aliadas a forças do governo serviam para regular e intervir na trama simbólica da cidade, estimulando, salientando e regularizando certas disposições mentais e de interação. "A renúncia da palavra (...) transfere a ênfase para a ação e coloca o conteúdo emocional das dimensões inconscientes das coletividades no centro da prática política, considerando a cidade como palco onde o seu drama é representado por elas e para elas" ${ }^{111}$. Essa mesma forma de intervenção era sentida na capital federal, que dentre inúmeros novos monumentos - e nesse caso a própria reformulação do espaço urbano por reformas urbanísticas -, a construção da estátua do Cristo Redentor simboliza a força e eloquência de um grupo social que buscava intervir também nesse contexto. A orientação dessas obras:

era antes de traduzir o presente como sinal profético do futuro. Em suma, produzir o transe do futuro permanente. Mais uma vez tempos aqui a conjugação do momento tecnológico presente com mecanismos arcaicos de simbolização. ${ }^{112}$

O que é importante compreender aqui é que esse conjunto de ações, falas, políticas, produções artísticas constitui um terreno em que qualquer ator social estava inserido e deveria dialogar. O vocabulário mobilizado, as perspectivas de futuro, as interpretações do passado, as incertezas no imaginário compunham um quadro que permite entendermos melhor o sentido do qual se revestem as palavras, as imagens, as mobilizações, ou seja, as ações - entendidas de forma 
ampla - de qualquer que seja o agente social em estudo. No caso de Amoroso Lima, não seria diferente. Compreender a forma com que o autor constrói seu pensamento católico baseado em conceitos e noções centrais, como pretendo fazêlo no próximo capítulo, só será possível se puder compreender, de um lado, o lugar social que ele ocupa no jogo político e, de outro, as formas de pensamento e a construção do imaginário simbólico que se construiu ao redor de sua geração.

O contexto linguístico, como afirmam Q. Skinner e J. Pokock, permitiria compreender a produção de significado que as palavras tomariam por meio do entendimento comum que elas teriam no contexto em que foram proferidas ${ }^{113}$. Nesse sentido, seria possível compreender, a partir do estabelecimento do contexto, o que John L. Austin - filósofo mestre e inspirador dos dois historiadores fundadores da Escola de Cambridge - chamou de Força Ilocucionária Intencional, ou seja, a intenção de significado que o autor confere a um ato de fala. As limitações dessa relação direta entre contexto e intenção - que traz consigo uma certa dimensão difusa de desvelamento da verdade - são bem conhecidas e não faria sentido insistir sobre as mesmas. Contudo, acredito ser possível, através dessa reconstituição, entender os lugares ocupados pelo crítico literário e militante católico, e vislumbrar uma possibilidade de compreensão de como as três dimensões do ato de fala tomaram forma. Esses três "tipos de atos", como o próprio Austin afirma, representam três forças com que uma frase se reveste: o ato locucionário, ilocucionário e perlocucionário. De maneira inicial, o primeiro seria a fala em si, o segundo, a intenção da fala, ou mais precisamente o que ela faz (o ato ilocucionário de "pare, agora!" seria a ação de ordenar que se cesse o movimento). O terceiro e talvez mais importante, o ato perlocucionário é a forma como um interlocutor entende e reage ao significado da fala (seguindo o exemplo anterior, seria o fato de o interlocutor ter sido parado) ${ }^{114}$.

A possibilidade de vislumbrar um indício ${ }^{115}$ de como se conjugam as forças ilocucionárias e perlocucionárias no interior e ao redor do discurso de Alceu é o que permitirá a compreensão de uma proposta de ação dentro dos moldes de uma historicidade construída de forma cuidadosa para dar as bases desse pensamento. Os significados desses discursos, das propostas de intervenção na memória coletiva e da identidade nacional, os significados dos quais poderiam se revestir os atos e as intervenções urbanas e artísticas se deram em um jogo que não tinha estrutura definida, mas que foi sendo formado na interação e na interrelação das 
dimensões econômicas, sociais, trabalhistas, urbanas, simbólicas e espirituais dos agentes que se lançavam à cena pública. Esses discursos distintos que foram se formando a partir de grupos ideológicos e sociais possuíam mecanismos e regras próprias, mas não podiam de estar inseridos no contexto maior da cena pública. É só a partir desse entendimento, ou da abertura para a possibilidade desse entendimento, que foi possível construir uma "descrição densa", para usar o termo de Clifford Geertz, da formação do pensamento amorosiano nos anos estudados. Geertz, que assim como Austin tem como referência a linguística pragmática de L. Wittgenstein, entende que

Como sistemas entrelaçados de signos interpenetráveis (...) a cultura não é um poder, algo ao qual podem ser atribuídos casualmente os acontecimentos sociais, os comportamentos, as instituições ou os processos; ela é um contexto, algo dentro do qual eles podem ser descritos de forma inteligível - isto é, descritos com densidade. (grifo meu $^{116}$

É nesse sentido que posso compreender como o imaginário da mobilização e da ação como força produtora de significados e mudanças nesta década conferiu sentido especial a toda vez que Amoroso Lima utiliza o termo ação ou semelhantes. Entendendo o lugar que ocupou como crítico literário atualizado com as tendências modernas europeias, posso perceber como 0 redimensionamento da "pintura como ação, não mais como contemplação" 117 dos modernistas se aliaram ao imaginário militante da Igreja de Sebastião Leme no momento da conversão de Alceu - e, mais além, o que as duas dimensões apresentam de proximidade. A leitura da Restauração Católica como movimento anti-moderno, reacionário pura e simplesmente, impede a percepção das confluências que teria com o contexto, no sentido de Geertz e de Skinner, e como essas confluências tomam forma esquematizada específica no pensamento de seu novo expoente em 1928.

Ao buscar compreender como essa ação, no pensamento amorosiano, se conjuga com uma concepção histórica, não posso perder de vista a "associação simbólica operada entre tempo e ação" 118 que as vanguardas europeias produzem como efeito colateral. Muito menos posso perder de vista que esse registro de temporalidade que o modernismo instaura na arte ganha contornos específicos no Brasil. A modernização esbarra em um desafio inesperado no contexto periférico brasileiro. A inserção no concerto das nações ${ }^{119}$ não se poderia fazer a menos que fosse reconhecida uma forma artística que estivesse ligada a uma identidade específica, particular. A perspectiva nativista do contexto modernista 
internacional seria associada a uma tradição já mais antiga no Brasil de busca por uma identidade nacional nas artes. Diferente do que se firmou na memória corrente do modernismo, essa associação não aconteceu naturalmente. Pelo contrário, segundo Eduardo Jardim, só a partir de 1924 os modernistas atentam de forma central para a importância da questão da nacionalidade na arte moderna.

Tendo o caminho aberto pela literatura que se desenvolvia no Brasil e no mundo desde antes da virada do século, o modernismo surgia com toda verve e eloquência na Semana de Arte Moderna de 1922 - apesar de estar em desenvolvimento desde anos antes, ainda acredito que a Semana é um evento central na compreensão da sistematização de uma primeira proposta modernista. Sua força insurgia-se como uma negação ao passado, um corte, ou melhor, uma atualização, uma forma de trazer as artes para o seu tempo. Acusando o campo artístico de elitista, fechado, antiquado, um mero reprodutor de formas antigas, os modernistas propunham uma nova forma de se fazer arte que estivesse em consonância com os novos tempos. É nesse momento que surge a revista Klaxon.

O manifesto que é o editorial da primeira edição da revista de arte moderna Klaxon carrega o ímpeto modernista da inovação, da negação do antigo em relação ao novo, aliado ao discurso totalitário e - se é possível dizer - protofascista que já eram característica dos manifestos futuristas de Marinetti. "Klaxon não se queixará jamais de ser incompreendido pelo Brasil. O Brasil é que deverá se esforçar para compreender Klaxon" ${ }^{120}$. A negação do passado aparece como a consciência da existência do mundo, em oposição a uma arte deslocada da realidade: "Klaxon sabe que a vida existe. (...) Klaxon sabe que a humanidade existe. (...) Klaxon sabe que a natureza existe. (...) Klaxon sabe que o progresso existe. (...) Klaxon sabe que o laboratório existe. (...) Klaxon sabe que o cinematógrafo existe." ${ }^{121}$. A oposição entre o século XIX e o novo século se dá exatamente com a ruptura da Grande Guerra e a criação a partir daí de um mundo novo, que preze a velocidade, a alegria, o movimento. "Século 19 - Romantismo, Torre de Marfim, Simbolismo. Em seguida o fogo de artifício internacional de 1914. Há perto de 130 anos que a humanidade está fazendo manha." e finaliza dizendo que a era das "lágrimas artísticas" acabou e que inicia-se a "era dos 8 Batutas, do Jazz-Band, do Chicharrão, de Carlito, de Mutt \& Jeff' ${ }^{122}$.

Em nenhum momento no manifesto de Klaxon, como nos chama atenção a análise de Eduardo Jardim, é figurada a condição do Brasil e das condições de 
possibilidade de uma produção nacional. As grandes questões que nortearam a memória sobre o problema da importação serão marcadas posteriormente, a partir da excursão que o grupo dos 5 realiza junto com Blaise Cendras ${ }^{123}$. A grande questão de Klaxon é, à vista das tensões que ocorrem no campo das artes europeias, a querela entre antigos e modernos, entre tradição e o novo, no movimento que sacramentou o que Octavio Paz definiu como "tradição da ruptura" 124 .

A problemática da situação periférica e ex-colonial do Brasil só irá surgir a partir de 1924, ano marcado pela publicação do Manifesto da Poesia Pau-Brasil, em 18 de março por Oswald de Andrade. Novamente, a frase que abre o manifesto retoma a relação entre arte moderna e realidade já apresentada em Klaxon: "A poesia existe nos fatos". Essa realidade, porém, agora é sabida como muito diferente da europeia: "Wagner submerge ante os cordões de Botafogo" ${ }^{125}$. É exatamente aí que o manifesto irá agir. O lado doutor, acusa, criou esse afastamento do Brasil com sua realidade, fez importar mais do que exportar, ficando a mercê do que vem de fora. Mas com a decadência da europa também na área das artes revela um momento propício para tomar força no que vem de dentro, como diz a frase referida de Blaise Cendras: "Tendes as locomotivas cheias, ides partir" ${ }^{126}$.

A tradição, que se preocupou muito em copiar o mundo de forma fidedigna, entrava em crise, e a época anunciava "a volta ao sentido puro. Um quadro são linhas e cores. A estátua são volumes sob a luz" ${ }^{127}$. A realidade que a poesia modernista deve buscar é a realidade última das coisas, e não a representação do aparente. Essa nossa realidade última deve ser exportada.

O Manifesto da Poesia Pau-Brasil é consciente de que vive um outro momento da produção modernista, e busca se situar nesse começo: "O trabalho da geração futurista foi ciclópico. Acertar o relógio império da literatura nacional. Realizada essa etapa, o problema é outro. Ser regional e puro em sua época” ${ }^{128}$. A questão estava dada; se em um primeiro momento o problema era o que não ser, no segundo momento a questão a ser colocada era exatamente o que ser. Questão colocada, mas não respondida. A proposta de uma poesia de exportação não passa disso: uma proposta, o chamar atenção para um problema.

Só quatro anos depois, em maio de 1928, que essa questão seria trabalhada com mais pormenores também por Oswald no Manifesto Antropófago: "Só a 
antropofagia nos une. Socialmente. Economicamente. Filosoficamente" ${ }^{129}$. Neste manifesto, Oswald desenvolve mais o caráter filosófico dessa proposta modernista do novo, baseando-se em um conceito chave que desenvolve-se por todo manifesto: a antropofagia.

Costume indígena, que consistia em deglutir os inimigos capturados em batalha para ganhar suas virtudes, a antropofagia surge na poética de Oswald como potência criadora. Associando as análises de Freud acerca do inconsciente e dos males da civilização europeia com elementos da história e da formação do Brasil, como o matriarcado de Pindorama ou os discursos do Padre Antonio Vieira, Oswald busca desenvolver uma forma de compreender um tipo de estética que esteja ligado com a formação nacional e com os elementos culturais aqui presentes. A negação da importação "enlatada" de costumes europeus se manifesta em uma aparente deformação ou adaptação ao que vinha de fora: "Nunca fomos catequizados. Fizemos foi carnaval. O índio vestido de Senador do Império" 130 .

As marcas da diferença entre a cultura europeia e a cultura brasileira, mesmo que esta seja influenciada por aquela, trespassam todo o manifesto: "Não tivemos especulação. Mas tivemos adivinhação" ${ }^{131}$, se referindo ao que era visto como um dos principais elementos da produção filosófica: a especulação.

É claro que inúmeros temas de Klaxon se mantém no Manifesto Antropófago, como o elogio à alegria e as críticas à tradição pelo que é chamado de "Torre de Marfim": "Expulsamos a dinastia. É preciso expulsar o espírito bragantino, as ordenações e o rapé de Maria da Fonte" ${ }^{132}$. Nesse sentido, a negação da cultura - e da decadência - europeia é a exaltação do brasileiro: "Contra a realidade social, vestida e opressora, cadastrada por Freud - a realidade sem complexos, sem loucura, sem prostituições e sem penitenciárias do matriarcado de Pindorama" ${ }^{133}$.

Esse processo de gradual centralidade da particularidade dentro das aspirações universalistas do movimento moderno, quando se colocam lado a lado os três manifestos - Klaxon, Pau-Brasil e Antropofagia - indica um de muitos caminhos que se poderia tomar no momento, bem como ao traçar sua narrativa histórica, um caminho acompanhado de perto por Amoroso Lima. O primeiro grupo modernista seria herdeiro, em parte, do pensamento de Graça Aranha, que em A Estética da Vida que entende que a integração no todo universal só é 
possível através da formação das particularidades. A nível global ou nacional, a integração das partes enquanto corpos distintos que compõem um todo múltiplo será o principal legado de Graça Aranha para o movimento modernista ${ }^{134}$. Ao longo da década de 1920, esse pensamento extrapolaria o âmbito artístico, e gradualmente os modernistas se veem mais empenhados "em se afirmar como elemento chave no processo de constituição da entidade nacional" ${ }^{135}$. Segundo Jardim: "A constituição de uma teoria da temporalidade da vida nacional vai possibilitar a reavaliação da situação de 'atraso' do contexto nacional. Ela vai também fornecer as bases da definição de um tempo da modernização próprio da nacionalidade" 136 .

A questão da nacionalidade não era assunto novo, muito menos exclusivo do grupo modernista no início da década. Desde anos antes a Liga Nacional já buscava essa congruência entre nacionalidade e literatura, e a Revista do Brasil se apresentava como um lugar de criação da literatura brasileira. Nessa revista o próprio Amoroso Lima fará sua estreia com os textos "Pelo Passado Nacional" (1916) e "Êxodo" (1917), que indicavam uma proposta de mobilização da tradição. Tradicionalista desde os primeiros anos, Alceu chamava atenção para a importância da revitalização do passado nacional. O que o modernismo faz, principalmente a partir de 1924, quando começa a se transformar na principal expressão artística, é revitalizar essa busca sob moldes e linguagens novos, trazendo a tona o elemento gerador da arte enquanto ação, de que trata Sevcenko.

Passando pelos anos 1920, a estética modernista ganha força, bem como ganha força o imaginário mobilizador de forças sociais. As propostas se pulverizam, entram em disputa em uma sociedade que esgotava seus moldes clássicos de estruturação. A partir da revolução de 1930, o campo se abre, e essas identidades em disputa, cada uma mobilizando de uma forma o passado, se armarão para tomar a dianteira na definição dos rumos do país, no momento em que as incertezas tomavam o lugar da decadência e a abertura tomava o lugar do esgotamento. 


\section{Capítulo II - A Ordem como Itinerário}

\subsection{Uma revista de cultura católica}

Recusando todos os movimentos políticos e artísticos que não tivessem no catolicismo como seu prisma de tradição, Jackson de Figueiredo se lançava à frente do incipiente grupo de intelectuais quando em 1921 fundou a revista A Ordem e, um ano depois, o Centro Dom Vital. A revista, que fora criada tendo em vista à formação de uma elite intelectual católica leiga e a participação nos debates acerca do futuro da nação nos meios políticos, trazia uma ideologia profundamente baseada nos princípios de autoridade e ordem, que fundamentaram o pensamento jacksoniano. Fundada por um pequeno grupo de intelectuais e sem nenhum capital inicial, a revista foi idealizada por Jackson como um meio de expor e divulgar as ideias católicas e com o objetivo de "trabalhar para a Igreja", como lembra Hamilton Nogueira, um dos cinco convidados ao Café Gaúcho, no Centro do Rio de Janeiro, em agosto de 1921, quando Jackson primeiro expôs seu desejo de criar um periódico que difundisse o ideário dos leigos militantes ${ }^{137}$.

Até 1928, quando Figueiredo falece e é substituído por Alceu Amoroso Lima, A Ordem manteve uma posição extremamente combativa e fortemente incisiva nas questões políticas e sociais do quotidiano. "Um cangaceiro amarrado à Igreja", como ele mesmo se definia ${ }^{138}$, o sergipano de temperamento firme e, por vezes, explosivo empreendeu uma ação calcada em um discurso moralizador, de defesa da ordem e dos costumes pautados por valores católicos tradicionais. Margareth Todaro, ao analisar Jackson de Figueiredo, afirma:

Jackson acendeu um poderoso movimento católico baseado no conceito de regeneração moral nacional e na mobilização dos intelectuais católicos. Sua orientação europeia coincidiu com a dos intelectuais católicos da classe alta, que não foram influenciados pelos movimentos nativistas da época. As soluções que ele propôs para um Brasil sitiado não diminuíram - ao contrário, ampliaram - a confortável relação com o governo, recentemente conquistada com dificuldade. Em poucas palavras, Jackson deu à elite da Igreja o que ela queria. ${ }^{139}$

Ao formular soluções para o que afirmava ser a crise do Brasil moderno, entendida como proveniente da degeneração moral e espiritual da nação, "esse grupo de pensadores católicos se pretendia a única alternativa válida entre um regime 'liberal' moribundo e a 'catástrofe' comunista" ${ }^{140}$.

Uma revista de cunho político que galvanizasse a ação política em torno a análises e propostas comuns, e que organizasse a leitura de mundo do grupo que 
buscava auxiliar a reaproximação da Igreja com o poder instituído, se fazia necessária. A forma da publicação periódica, como estrutura mais eficiente de organização de grupos partidários e de difusão sistemática de discursos, fazia da criação da revista uma das primeiras e mais centrais frentes de trabalho. O Centro Dom Vital, fundado um ano depois como forma de arrecadar fundos para a revista, ao longo do tempo aculmulará força e prestígio, crescendo em amplitude e em projetos.

É nesse sentido que a revista tomaria forma nos primeiros anos de sua existência. Seus colaboradores se lançavam à arena pública como uma articulação dos "verdadeiros católicos" dedicados a trabalhar em prol da Igreja e da moral católica. O pensamento romanista, a partir da divisão que passou a fazer entre católicos por comodidade e os verdadeiros fiéis, fazia dos leigos militantes o seu centro articulador, e buscava formar uma linha de frente no que entendia como uma cruzada pela recristianização da nação - como o próprio Jackson se identificava como um soldado a serviço da Igreja. A Restauração ganhava a forma de uma tomada de consciência, pois mesmo que o Brasil fosse à época uma nação de maioria católica, esses fiéis teriam, na concepção do grupo, se acomodado a uma religiosidade fraca e não exerciam o seu papel de luta pela Igreja. No primeiro número da revista, apresentava-se como texto inicial o programa que dava as bases à publicação. Segundo ele "o mal que mais fundamente fere a nossa sociedade no regime republicano (...) não é esta ou aquela doutrina malsã (...). O mal vem de mais longe e é o que se pode denominar de horror à luta, de horror às posições definidas" ${ }^{141}$, e continua:

A direção dessa revista não sofre a moléstia do pessimismo. Pelo contrário. Se protesta contra esse estado de coisas, que nos desonra, é justamente porque crê que será ouvida, acredita que o momento é chegado em que, reduzidos como estamos a uma quase asfixia, das nossas mais nobres aspirações, reagiremos todos. ${ }^{142}$

A restauração buscava a formação de uma consciência católica aguerrida, e para isso era imprescindível um discurso intelectual que desse base a essa mobilização. O contexto de surgimento da revista A Ordem indica a centralidade da figura do intelectual como ponta de lança da ação da Igreja na sociedade, forma de liderança que a partir das elites letradas conduziria o povo a um caminho adequado. A construção de uma leitura do mundo que entenda a Igreja como agente e a religião como fundamento era central para os planos da hierarquia católica. 
Nessa visão, a hierarquia e a ordem eram vistas como os pilares de toda organização social. Por isso é o grupo intelectual, quando associado à Igreja, que poderia liderar a sociedade no que era visto como o caminho da salvação. Segundo Mônica Pimenta Velloso,

a revista A Ordem e o Centro Dom Vital (1922) surgem num contexto social que tende a adotar uma cosmovisão cada vez mais agnóstica. A luta que a inteligência católica trava é no sentido de legitimar-se perante essa sociedade, combatendo os seus erros políticos e religiosos. (...) A elite é chamada a reconverter-se aos princípios do catolicismo sob o lema 'Saneamento dos saneadores', tendo a missão de difundí-los na massa. A fundação da revista A Ordem e do Centro Dom Vital por Jackson de Figueiredo anuncia novos tempos para a Igreja, que, através da mobilização do elemento leigo, procura impor-se como força social significativa. ${ }^{143}$ Uso aqui a esquematização feita por Velloso, que divide a revista em pelo menos três momentos cruciais. O primeiro, de 1921, quando é criada, até 1928, ano da morte de Jackson de Figueiredo. Durante esse tempo, Figueiredo conferiu à revista um caráter eminentemente político de atuação, muito próximo ao seu temperamento público. A forma como a revista age e reage ao mundo a seu redor se dá de forma muito direta e moralista em sua dimensão política. A partir de 1928, quando Alceu Amoroso Lima assume sua direção, a revista ganharia outro caráter, mais de reflexão cultural, dentro do que denomina “cultura geral". Nesse período, de 1928 a 1934, a revista busca consolidar as bases do que seja um pensamento católico mais elaborado, preocupação que Amoroso Lima trazia para o laicato católico. A partir de 1934, promulgada a nova constituição, a revista voltava a se debruçar sobre as questões da ordem político-ideológica de forma mais constante até que em 1937, com o golpe do Estado Novo,ela novamente precisaria reconfigurar-se, agora sob um regime autoritário.

Nos primeiros anos, a revista apresenta um caráter quase que exclusivamente político, e busca lançar as bases do que seria uma ideologia política católica. "No seu primeiro ano de publicação, o discurso ideológico da revista enfatiza o seu caráter reacionário" ${ }^{144}$, no sentido de reagir a toda corrente de pensamento, crença ou política que esteja fora do seu escopo político. A revista se reveste de uma postura política baseada na moral e no pensamento reacionário católico de forte influência no conservadorismo nacionalista de cunho católico francês, em especial a Action Française - e de pensadores como Joseph de Maistre e Louis de Bonald.

Ainda no texto de lançamento da revista, afirma-se que 
essa revista terá (...) caráter acentuadamente nacionalista, dentro de seu programa de catolicismo integral. Cremos no brasileiro, na sua capacidade moral e intelectual, e, conformando-nos rigorosamente com as regras hierarquizadoras, com as distinções reconhecidas pela Igreja Católica no seio da humanidade, faremos tudo quanto um católico pode e deve fazer contra o bastardo espírito do cosmopolitismo, que é talvez fator principal de nosso ceticismo social, até o presente. ${ }^{145}$

Esse cosmopolitismo, qualificado como bastardo pela redação da revista, era associado ao mundo liberal de cunho burguês, e a moral burguesa era entendida como o principal problema do marasmo e da incapacidade de ação da população. No contexto de crise do mundo liberal alardeado pelo grupo católico e não só por ele - a reação à modernidade era entendida como o principal ponto na construção de uma nova ordem social. A revista se mostra de acordo as indicações de Dom Sebastião Leme, em consonância com as diretrizes do papa Pio XI, que conferia centralidade às iniciativas de caráter intelectual, aproximando ciência e fé. Busca, portanto, dialogar com as elites através da chave da discussão intelectual, pois entendia que é este grupo o "promotor das mudanças sociais", que segundo a ideologia tradicionalista defendia a necessidade de uma revolução espiritual "de cima para baixo" ${ }^{146}$, de onde deve partir a reação.

Tal pensamento não é exclusividade deste momento, e já estava presente na obra do Padre Júlio Maria, que na conclusão de seu livro "A Igreja e a República", publicado em 1900, afirmava que no Brasil não poderia "haver senão duas forças: a Igreja e o povo", e que o dever de todos os católicos, principalmente do clero, era a sua união ${ }^{147}$. Apesar de já afirmar isso décadas antes de Dom Leme e Jackson, é só o contexto da Restauração que lança no campo de forças a figura do intelectual católico leigo, responsável por promover essa aproximação de forma orgânica na sociedade.

Jackson de Figueiredo, leigo militante, encarna a doutrina da ordem $^{148}$ a partir de sua atuação, vista como um apostolado, de caráter intelectual reacionário. É com ele e seu catolicismo participante "de tom audaz e impetuoso", antevisto pelos brasileiros apenas em Júlio Maria ${ }^{149}$ que, segundo Antonio Carlos Villaça, "passamos da primazia do literário à primazia do ideológico" ${ }^{150}$. É com a ação intelectual, em consonância com as ações doutrinárias da Igreja - procissões, missas campais, festas -, a partir de uma rede difusora de ideias que discuta a ordem do mundo, que o projeto católico toma forma. 
O discurso da revista é marcado por um tom amplamente moralista e maniqueísta, no qual todos os problemas são interpretados a partir da lógica da desmoralização do mundo. "Fatos sociais, políticos, econômicos são analisados por esse prisma", e os comentários e análises políticas tem em vista a luta moral. Por isso, como chama atenção Monica Pimenta Velloso, "elogia-se o veto de Epitácio Pessoa ao orçamento das despesas do ano" em relação ao carnaval e o próprio problema da eugenia é visto como um "problema eminentemente moral" 151.

O nacionalismo da revista parte do pressuposto, que constituirá a base do pensamento católico desse momento, segundo o qual o Brasil é uma nação católica, e por isso ser católico - no sentido de engajamento militante com o qual usam o termo - é ser patriótico. Além disso, a oposição entre um poder de ordem "revolucionária" e um de ordem "moral" são postos como forma de mostrar que as saídas para o fim do liberalismo burguês são duas: uma certa, católica, e outra deformada, comunista. A revista no geral, atribui ao próprio materialismo liberal o surgimento do comunismo como força política no século. Esses e outros temas que estão presentes nesta primeira fase da revista terão eco na formulação que Alceu Amoroso Lima faz dos problemas do país, e pode se ver a continuidade do pensamento católico através de seus expoentes intelectuais como fios discursivos que constroem coerência interna entre os membros do grupo.

Ao longo da existência da Ordem, ela foi paulatinamente abrindo-se a apresentar vozes diferentes. Em seus primeiros volumes, o texto da revista é apresentado de forma única, direta e sem autoria. Uma voz única que fala à população ou a sua elite letrada, um projeto. As assinaturas que figuravam na primeira página mostravam a proeminência da figura de seu diretor, Jackson de Figueiredo, e do secretário, Perillo Gomes. A partir da edição de outubronovembro de 1923, apareceriam, embaixo do nome de Jackson, no cabeçalho da primeira página da revista, o nome dos redatores: Hamilton Nogueira, Jonathas Serrano, José Vicente de Souza e Perillo Gomes. O próprio corpo da revista paulatinamente abria-se mais para textos assinados. No volume de janeiro de 1926 começa a figurar, na sua nova folha de rosto, um sumário com o título dos textos presentes na edição e seus autores, coisa que havia acontecido em poucas edições até então. A revista passou por um processo de expansão e diversificação de vozes que a partir de 1928 ganha sentido muito mais amplo. 
É o que chama atenção Guilherme Arduini, ao analisar algumas vozes presentes na revista. $\mathrm{O}$ autor mostra que, apesar de a publicação apresentar uma linha definida, ao passo que seu poder de aglutinação vai aumentando, aumentam também internamente as vozes em disputa.

$\mathrm{Na}$ medida em que o grupo ganha força como articulador da identidade católica em diversas esferas da vida social, evidencia-se também uma disputa pela definição de 'catolicidade' e como mobilizá-la diante dos dilemas vividos durante esse período. ${ }^{152}$

Os intelectuais ligados ao Centro Dom Vital, apesar de engajados em uma causa comum, constroem um quadro de vozes diversas e em disputa. As diversas crônicas que vão surgindo apresentam discursos diferentes, por vezes opostos. Entre a Crônica Política de Heráclito Sobral Pinto, que responde à necessidade da revista de abordar os recentes acontecimentos e estabelecer uma ação baseada na análise do presente, a Crônica Feminina de Lúcia Miguel Pereira, que busca fazer frente às correntes femininas lançando-se em outro campo de disputa das questões sociais, e outras crônicas, a revista vai construindo um quadro de tonalidades mais variadas. Isto expressa-se em inúmeras evidências, como as discussões de ideias entre Alceu Amoroso Lima e Pedro Dantas, pseudônimo de Prudente de Moraes Neto, nas crônicas literárias. O segundo, expoente do movimento modernista e que em 1924 havia fundado com Sérgio Buarque de Hollanda a revista Estética, sai da Ordem em 1931, substituído por Jonathas Serrano na crônica literária ${ }^{153}$.

Essa saída marca uma inflexão no teor na crônica, que até então se mostrava muito aberta à produção nacional de forma ampla, e que a partir daí se comprometeria a tratar quase que exclusivamente de temas católicos. Essa inflexão, a partir da intensificação dos debates políticos quando os rumos da Revolução de 1930 estavam ainda em aberto, se mostra em boa parte da revista. São menos comuns textos como o de Augusto Frederico Schmidt em 1928, na primeira edição da "nova série" - após a mudança de diretor - que analisa a obra de Mário de Andrade, Macunaíma, tecendo uma crítica quase sem teor religioso da construção do caráter do personagem em sua dimensão de metonímia brasileira. A preocupação da revista em construir uma escola de pensamento consolidada faz com que ela volte-se mais para o pensamento católico.

Essas mudanças não escondem o fato de que, a partir de 1928, a revista apresenta um caráter mais amplo e cultural. Foi possível ver como, mesmo que se possam esquematizar fases gerais entre as quais o caráter da revista se altere, tais 
fases também apresentam mudanças internas constantes. Contudo, ainda uma das mais radicais e evidentes é a inflexão no teor da revista quando Amoroso Lima assume sua direção.

Jackson, que despontava como figura de proa da movimentação política do laicato católicos, no auge de sua atuação, faleceu de modo repentino. $\mathrm{O}$ vazio de sua ausência foi logo ocupado por Alceu Amoroso Lima à frente do Centro Dom Vital e da Ordem. Apesar de convertido naquele mesmo ano, Alceu tinha uma longa relação epistolar com Jackson, com quem trocava correspondência desde 1919. Nas cartas, ele abre suas angústias e suas dúvidas para o homem que viria a ser seu principal mentor e o responsável por sua conversão em 1928. Durante esse período, passou, na convivência com Jackson de Figueiredo, por um longo e paulatino processo de conversão, e viria a assumir o lugar de seu mestre não apenas à frente da Ação Católica, mas como mentor e mecenas de vários literatos que a ele vinham com o que denominava de angústias da alma, dentre eles António Alcântara Machado e Carlos Drummond de Andrade, este assíduo assinante d'A Ordem. A metanóia de Amoroso Lima ganha dimensão nova quando, agora (re)convertido e subitamente lançado à direção da revista, ele deverá representar a imagem de católico ideal.

Alceu, sob a orientação do Padre Leonel Franca, assistente eclesiástico do Centro, com as bênçãos de Dom Leme e à frente d'A Ordem, dará novos ares à revista. A "orientação jacksoniana” afirma Salem sobre o período anterior a Alceu “- e, portanto, também do grupo que reuniu à sua volta - mais do que cultural, conforme inicialmente pretendida, foi predominantemente política" ${ }^{154}$. Com Alceu, a revista mudaria consideravelmente sua abordagem. Na edição que marca o começo da nova era, escreve:

Não venho substituir meu amigo. Venho apenas suceder-lhe. (...) Nossos projetos sobre a revista serão apenas de prosseguir quanto possível na obra de criação de uma cultura católica superior, entre nós, como sempre fora o intento do nosso intrépido fundador. (...) Sendo assim, A Ordem perderá naturalmente o caráter político, que em tempo possuiu, e que só a genialidade de nosso fundador conseguia manter, nesses horizontes atormentados e sombrios dos nossos destinos. Nossa ambição é mais modesta, como mais fracas as nossas forças. A Ordem passa a ser agora uma revista católica de cultura geral, visando mais a inteligência que os acontecimentos. ${ }^{155}$

Essa "ambição mais modesta", aparente a princípio, se mostra uma forma mais efetiva de apelo às camadas intelectuais. O termo "cultura geral", nesse contexto, remete a uma produção intelectualizada que não está diretamente ligada 
a projetos políticos ou a interesses, mas que seria "desinteressada", para utilizar um termo da época, buscando apenas "a verdade". Essa produção pretensamente desinteressada, de aspecto erudito e científico, é o caminho que o acadêmico Amoroso Lima encontra como sua marca e que se reflete no surgimento, na nova série da revista, da epígrafe em francês de Ernest Hello traduzida como "A Ordem é a lei do mundo natural e sobrenatural".

A mudança no Centro Dom Vital, enquanto polo irradiador da doutrina católica nos meios intelectuais leigos, teria grande impacto na forma e na força que este grupo tomará a partir da década de 1930. Vinculado à formulação mais ampla do que seria o laicato católico, expressa pela mudança de foco d' $A$ Ordem e com um contexto nacional que irá se tornar cada vez mais propício à aproximação dos católicos ao Estado, a Ação Católica, como movimento coeso, ganha força e obtém diversas vitórias no plano político e social. Inúmeras agremiações, então, passam a ser formada orbitando do Centro Dom Vital. Entre elas, estão a Liga Eleitoral Católica (LEC), a Associação Universitária Católica (AUC), os Círculos Operários Católicos e a Confederação Católica de Educação. Algumas instituições também são fundadas neste segundo momento da Restauração, como o Instituto Católico de Ensinos Superiores (ICES) e o Instituto de Educação Social e da Família. Também dirigida por Amoroso Lima, a Ação Católica é formalmente institucionalizada em 1935, a fim de coordenar e sincronizar todos os órgãos e agremiações católicas que então se formavam, herdeira da Coligação Católica Brasileira, criada nos anos anteriores.

A abertura da revista para assuntos que seu diretor denominava de "cultura geral" é o primeiro passo que permite uma consequente abertura de campos de atuação que levariam a uma penetração maior do laicato católico no mundo intelectual. A reforma realizada por Alceu na revista e sua ação é de importância ímpar na trajetória da revista e também no fortalecimento do movimento restaurador capitaneado por Dom Leme.

A retração da atuação política direta, também sob indicação eclesiástica, se de um lado mostra um arrefecimento da radicalização do discurso da revista, por outro amplia o seu horizonte sob a chave da análise do mundo. Alceu, diferente de Jackson, era um acadêmico. Segundo Villaça, ao palanque de Jackson, preferia a casa e os livros. Ao comício, as nuances. À intuição, a racionalidade analítica ${ }^{156}$. Foi lançado à liderança do engajamento católico por circunstâncias ${ }^{157}$, e pretendeu 
levar a cabo um trabalho de fundamentação teórica do pensamento católico não só a partir de seus textos, mas a partir da própria estrutura da revista e do Centro. As organizações ampliavam as áreas de atuação do laicato nos seus dois polos principais de ação, e o cunho de cultura erudita da revista deu amplitude para uma análise, na perspectiva católica, de uma gama muito maior de fenômenos. O foco da ação da revista deslocava-se da política para a análise e o convencimento.

A mudança pode ser vista ao comparar-se os dois momentos. Na edição de julho de 1922, fazendo referência à repressão por parte do governo no episódio que ficou conhecido como os dezoito Forte, a revista trazia a foto do presidente Epitácio Pessoa. Embaixo da foto, pode-se ler “Ao exmo. Sr. dr. Epitácio Pessoa, Presidente da República, as nossas mais sinceras homenagens pelo exemplo de coragem e de civismo que legou aos seus compatriotas, na defesa das instituições e da ordem pública, em face dos gravíssimos e lutuosos acontecimentos deste mês" ${ }^{158}$. Em defesa da ordem, o grupo se posicionava contra todo tipo de insurreição ou quebra da hierarquia.

Mônica Velloso, sobre a edição de novembro-dezembro do mesmo ano, chama atenção que,

A revista dá total cobertura a Arthur Bernardes, à medida que ele representa a reação contra a onda revolucionária. Em um dos seus números correspondente ao ano de 1922, traz sua fotografia estampada, logo na primeira página; transcreve e apoia alguns tópicos da sua mensagem enviada ao Congresso sobre a sedição militar, lei de imprensa e estado de sítio. ${ }^{159}$

Nesses casos, a manutenção da ordem sobre o caos e a revolução são a base para que se defenda a atitude de repressão do presidente da república, em alto grau de personalismo político. A revista chama a atenção e cria valores sobre atos individuais, pois pretende atuar politicamente da forma mais direta, apoiando e repudiando atos e personalidades políticas.

Se comparada com a ocasião da tomada do poder de Vargas, em 1930, o contraste fica claro. Um texto de Tristão de Athayde abre edição de outubro de 1930 sob o título de "Palavras aos Companheiros". Nele, afirma que

Justifica a não interferência direta e ação secular sobre os acontecimentos que acometem o Brasil. A Ordem deve manter seu caráter supra-político, tratando das raízes dos problemas (cultura superior) e não do descortinar dos acontecimentos efêmeros. (...) Se a República brasileira se afoga hoje em sangue é que esqueceu por quarenta anos essa norma fundamental da vida de um povo, como da vida de cada homem. (...) A Revolução que aí temos não é obra dos governos nefastos nem das oposições extremadas. Ela é obra da Constituição sem Deus, da Escola sem Deus, da Família sem Deus, das consciências sem Deus. ${ }^{160}$ 
E continua afirmando que restituí-las a Deus é "o único caminho da paz" ${ }^{161}$. No número seguinte, de dezembro de 1930, a edição é novamente aberta com texto assinado por Tristão, intitulado "Indicações". Nele, Alceu reitera suas posições no texto anterior e dá algumas indicações de caráter temporal. Reforça que o caráter não religioso da revolução justifica a não intervenção, e sugere que os extremismos que então banharam de sangue a República seriam resultado de uma política e de um governo sem Deus. Reitera que o dever dos católicos não estava na política secular, a "areia movediça" do plano dos acontecimentos, mas no terreno sólido dos princípios ${ }^{162}$. "A Igreja não é revolucionária nem contrarevolucionária; é extra-revolucionária" ${ }^{163}$. Por isso o dever dos católicos seria o de "trabalhar para que a apostasia republicana de quarenta anos, que é até hoje a maior culpada pelo que estamos passando, venha finalmente a terminar de modo que o Estado e os seus governantes voltem às verdadeiras raízes da nossa nacionalidade" ${ }^{164}$. Preocupa-se com uma futura constituição, na qual possa voltar-se o Brasil a rever os princípios do governo e do Estado.

$\mathrm{O}$ texto de Alceu sugere que antes de comemorar ou repudiar a ordem dos acontecimentos, deve-se fazer o melhor com o que acontece, sem interferência política direta. Mais do que um partido, o laicato seria um pai, que conduz a nação para os caminhos certos e ensina sem intrometer-se. A preocupação das indicações aos católicos é a de mostrar como a ausência de Deus conduziu a isso, e como pode-se aproveitar o momento de incerteza para que a nação volte ao rumo certo, e para isso elenca seis princípios a serem defendidos em uma possível constituinte que vão desde a citação explícita de Deus na constituição até o direito político de padres e seminaristas, além do reconhecimento do casamento religioso, além da já antiga pauta da educação católica, que será analisada mais adiante. Diz Alceu que só assim "teremos iniciado o movimento de reforma social cristã, que virá reintegrar a nacionalidade em suas bases verdadeiras e estáveis" 165 .

A partir de 1931, cada número da revista traria um edital, sem autoria, que tenta construir as bases de uma interpretação mais profunda do momento e das formas de ação no mundo moderno. Os textos editoriais de abertura da revista são pensados como forma de conferir uma organização e uma direção à ação dos católicos, em momento tão grave quanto o pós-revolução. Tratarei melhor destes editoriais mais a frente, tendo motivos para supor a autoria ou pelo menos forte influência de Amoroso Lima em sua redação. A partir de 1934, os textos de 
abertura da revista passam a ser assinados pelo próprio Alceu, sempre sob seu pseudônimo. No ano de formação da assembleia constituinte, em 1933, pode-se perceber também um caráter cada vez mais ampliado da revista, trazendo novos autores e textos mais longos e de teor mais especializado, como estatísticas, tratados de psicologia, geografia etc.

Comparando esses dois momentos, um em 1922, acerca dos episódios de insurgência militar sob os governos de Epitácio Pessoa e Arthur Bernardes, e o outro em 1930, no contexto da Revolução de 1930, pode-se perceber a inflexão da revista de modo mais claro. Ao propor ser uma revista de cultura geral, A Ordem buscava uma atuação muito mais disseminada na dimensão dos princípios com os quais a política - qualquer que fosse a situação ou a efeméride - se revestia. Essa fase, porém, se mostrava também mais aberta ao mundo moderno, interpretando-o de modo a entender novas formas da catolicidade dentro dele, nessa miríade de vozes internas que a revista apresentava. Além disso, a inflexão da revista indica uma diferença radical entre a leitura do mundo dos dois diretores. De uma interpretação moralista da política vista como a única possibilidade de mudança, a revista se expande para uma visão de uma sociedade que constrói significados e baseia seu conhecimento em saberes consolidados. Para usar termos externos ao vocabulário dos autores, esse pensamento do social enquanto produtor de sentido, e consequentemente de políticas, é aliado à visão hierárquica do catolicismo numa interpretação de que é a cultura erudita que dará as bases da mudança nacional não em termos da realpolitik, mas de uma mentalidade coletiva.

Em oposição, o período de Jackson de Figueiredo demonstra uma interpretação da Igreja muito mais rígida e a-histórica, moralista e mais associada à sua interpretação tridentina. Pode-se dizer que a direção desta mudança, quanto ao mundo em que está inserida, parte da negação e chega à interpretação.

\subsection{O intelectual e o itinerário}

É comum nos estudos sobre a Ação Católica no Brasil que se ressalte a importância dada à formação de uma elite intelectual que se pautasse por ideais católicos e que levasse as reivindicações da Igreja, ou melhor, da catolicidade, às altas instâncias do poder e da sociedade. Não é à toa que a criação das Faculdades Católicas - primeiro no Rio e pouco tempo depois com a Universidade Católica de São Paulo - é vista como marco dos mais significativos neste empreendimento de recatolização da nação. A frase de Alceu Amoroso Lima, em alocução na 
ocasião da instalação dos cursos das nascentes Faculdades Católicas em 1941 no Rio de Janeiro, dá a entender a importância dos intelectuais que ali seriam formados:

A história nos ensina que foram sempre pequenos grupos de espíritos selecionados que dirigiram os acontecimentos e mudaram a face dos povos e dos tempos. ${ }^{166}$

É nesse sentido que o primeiro Anuário das Faculdades Católicas, de 1941,

define a universidade como

o centro onde se elaboram as grandes sínteses do saber, o seminário de formação dos sábios que impulsionam os progressos do conhecimento, o laboratório em que se preparam os elementos superiores da administração e da vida profissional do país, numa palavra, o órgão conservador e transmissor de todo o patrimônio de uma civilização. ${ }^{167}$

No mesmo Anuário, a Universidade Católica, que tinha seu primeiro passo expresso nas Faculdades nascentes, é descrita como "um grande centro de irradiação doutrinária" ${ }^{168}$. O Padre Leonel Franca, fundador e primeiro reitor da instituição, afirma que "a Universidade é essencialmente transmissora de cultura", e que sua missão é "formar o homem superiormente culto", que é em última instância, criador desta cultura, pois é a esses "homens privilegiados a quem a Providência confiou a missão de iluminar" 169 .

A centralidade desta figura no esforço empreendido pela Restauração Católica já se encontra na Carta Pastoral de Dom Leme, de 1916, quando atenta para o afastamento dos ramos da vida pública e política em relação aos ideais católicos:

Enfim, na engrenagem do Brasil oficial não vemos uma só manifestação de vida católica. O mesmo se pode dizer de todos os ramos da vida pública. Anticatólicos ou indiferentes são as obras da nossa literatura. Vivem a achincalhar-nos os jornais que assinamos. ${ }^{170}$

A intelectualidade leiga militante seria o ponto principal através do qual a Igreja exerceria seu poder. O laicato católico era visto como o grupo que poderia aproximar de forma orgânica a duplicidade Igreja-Povo já identificada pelo padre Júlio Maria. A reconstituição da catolicidade no imaginário da população se daria, segundo a Igreja, a partir da luta pela visão católica de educação e da formação de uma intelectualidade leiga católica que atuará como força motriz da mudança cultural, social e política. É essa dimensão que Alceu Amoroso Lima encarnaria. Diretor da Ordem e do Centro Dom Vital a partir de 1928, Alceu viria a liderar diversas instituições e organizações católicas leigas, como a LEC, a própria Ação Católica Brasileira, a Coligação Católica. Sua influência, tanto pessoal percebida principalmente em sua extensa atividade epistolar, pela qual manteve 
contato com diversas figuras do cenário intelectual da época - quanto em seus escritos - principalmente na revista A Ordem, a partir de sua conversão - que o puseram em lugar de destaque e, principalmente, de conciliação do laicato católico com o cenário nacional.

Amoroso Lima já gozava de prestígio e atenção antes mesmo de ser arregimentado para as fileiras militantes da Igreja. Sob o pseudônimo Tristão de Athayde, ganhou espaço no meio intelectual por suas críticas, publicadas n'O Jornal, periódico de grande prestígio na época. Foi o responsável por lançar vários autores modernistas na cena nacional, e acompanhou de perto a Semana de Arte Moderna e o desenvolvimento do Modernismo ao longo da década de 1920. Ao se converter, em 1928, Amoroso Lima já tinha uma história de quase dez anos como crítico, considerado um modernista moderado, homem de aguçado olhar crítico e de grande influência. Desde 1919 mantinha correspondência com Jackson de Figueiredo, e foi graças à influência do amigo e mestre que Alceu acabou por se converter ao catolicismo. Herdeiro do pensamento jacksoniano, o substituiria no comando do laicato católico após o seu falecimento, levando a cabo o projeto de Jackson e Dom Leme de formação de uma intelectualidade católica praticante e liderando a atuação desta na sociedade.

Não se deve ignorar o fato de que existiram, antes desta dupla mobilização de Figueiredo e Sebastião Leme -, intelectuais ligados à Igreja e empenhados em defendê-la. A partir de Jackson de Figueiredo, porém, surge um novo tipo de intelectual católico - militante, envolvido nas disputas sociais e políticas, representante do ideário da Igreja - que seria a expressão secular da busca pela neocristandade. Como afirma Margareth Todaro em passagem já citada, Jackson acendeu um movimento de grande força calcado "no conceito de regeneração moral nacional e na mobilização dos intelectuais católicos" ${ }^{171}$.

Esta nova imagem de intelectual, baseada na distinção entre verdadeiros católicos - praticantes, militantes - e aqueles por tradição e comodidade, seria o cerne da busca da hierarquia, no duplo movimento de secularização da Igreja e sacralização do mundo secular. O Centro Dom Vital sob a direção de Jackson de Figueiredo foi expressão da ideologia restauradora da Igreja. "Foi graças a Jackson de Figueiredo, em conluio com Dom Leme, que se presencia pela primeira vez no Brasil o engajamento de intelectuais católicos na vida pública" 172, afirma Tânia Salem. Essa intelectualidade, que desde sua formação irradia do 
Centro Dom Vital - e que consequentemente, sob a direção de Jackson, tem característica combativa de forte cunho político - tem, com Alceu Amoroso Lima, uma reformulação. A atuação da militância católica ganha o âmbito cultural que lhe permite penetrar mais profundamente nas camadas populares e no governo. $\mathrm{O}$ Padre Leonel Franca, eleito por Dom Leme assistente eclesiástico do Centro Dom Vital, coroa esta nova faceta da instituição. Seus escritos e sua atuação reafirmam e fortalecem os novos rumos que tomava o Centro. Padre Franca tinha uma preocupação específica com a presença católica no mundo acadêmico, e sua atenção dada ao ensino superior também será um ponto chave nessa nova fase da intelectualidade católica. Segundo Salem,

sob a tríplice liderança de Dom Leme, Alceu e Franca, o movimento sofre uma mudança de angulação. A ideia professada pelo bispo - em concordância com os desígnios da Santa Sé - de que a função espiritual da Igreja estaria estreitamente ligada a uma missão cultural, é estimulada por esses dois colaboradores que, ao contrário de Jackson de Figueiredo, eram personalidades intelectuais. ${ }^{173}$

Essa mudança de angulação observada por Salem faz com que a influência

do Centro Dom Vital cresça enormemente. Rompe com a ideia de incompatibilidade entre o intelectual e o religioso e, consequentemente, entre fé e razão. Todaro afirma que "por alguns poucos anos ser sócio consistiu simultaneamente em um símbolo de classe, prestígio, intelectualidade e espiritualidade" 174 .

Amoroso Lima, à frente do Centro, assume a figura de católico modelar, o modelo no qual se encarnava o esforço católico da formação de um laicato atuante. Ao converter-se, empreenderia um projeto de consolidação do pensamento católico baseado em um itinerário. Entre 1928, ano de sua conversão, e 1934 publica cerca de vinte obras - o período de produção mais intenso de sua vida -, dentre análises sociais (Problema da Burguesia; Preparação à Sociologia), econômicas (Introdução à Economia Moderna; Economia Pré-Política), políticas (Política; Pela Reforma Social), jurídicas (Introdução ao Direito Moderno; O Materialismo Jurídico e suas Fontes), entre outros.

A ideia de itinerário é muito presente nas produções sobre Alceu, especialmente nesse período. A profusão de livros publicados indica não somente o "arrebatamento do convertido" ${ }^{175}$, mas a definição de um programa, de um itinerário, que indica a dupla atuação intelectual naquele momento: consolidação teórica e maior inserção nos meios de produção intelectual. Marcelo Timotheo da Costa identifica como sendo o móvel para tantas publicações "resguardar os 
postulados católicos da neocristandade, além de conquistar espaço institucional, como o das cátedras universitárias" ${ }^{176}$. Com isso "Alceu, convertido, preservou e até ampliou sua inserção na sociedade civil leiga, na imprensa e na academia" 177 .

Ele é incentivado por Dom Leme a prestar diversos concursos a cátedras do ensino superior, como forma de inserção nos círculos mais internos da cidade letrada ${ }^{178}$. Daí resultam algumas de suas publicações, tendo em vista que boa parte dos concursos para professores exigiam uma tese inédita a ser apresentada. Foi o caso de Economia Pré-Política e O Materialismo Jurídico e suas Fontes, apresentados para concursos para a cátedra de Economia Política e de Introdução à Ciência do Direito, ambas para concurso na Faculdade de Direito do Rio de Janeiro. Sérgio Miceli atenta para a importância dos concursos nas discussões políticas e na busca por inserção no campo de relações intelectuais, seja como grupo ou como sujeito:

Os concursos havidos na Faculdade de Direito do Rio de Janeiro no início da década de 1930 revelam (...) os móveis centrais das lutas no campo intelectual da época, na medida em que permitem aferir o valor social atribuído a postos intelectuais e o estado da concorrência em relação às posições mais cobiçadas. $\mathrm{O}$ móvel da concorrência entre os candidatos às cátedras deslocou-se do terreno estritamente jurídico para a esfera das teorias políticas e sociais acerca do papel do Estado. ${ }^{179}$

A situação dos intelectuais a quem Miceli alcunha "bacharéis livres" ${ }^{180}$, de sujeição ao campo de forças de legitimação e inserção, é visto pela hierarquia da Igreja como um ponto de inserção da Ação Católica nas estruturas regulares do poder. Essas disputas para as quais o autor chama a atenção têm seu paralelo e espelho no campo discente, através das disputas estudantis, como se verá mais adiante.

A vasta produção de Alceu nesse período reveste-se de uma importância dupla: de um lado, a consolidação de sua imagem pessoal enquanto herdeiro de Jackson de Figueiredo, católico, cruzado a serviço da Igreja, afirmando seu lugar enquanto pensador e, de outro, sua produção ganha o status de uma posição semioficial da Igreja, o norte de toda ação católica leiga intelectualizada. Alceu investe pesadamente em posicionar-se como modelo e modulador do ethos leigo neste momento. A seus livros publicados sempre seguem-se análises de outros autores publicadas na revista A Ordem, e diversas vezes foi possível perceber uma temática que, perpassando um número da revista - desde o edital até discussões e 
comentários - era pautada por uma publicação do autor. A partir dessa posição, segundo Timotheo da Costa:

Amoroso Lima passa a circular em espaço católico privilegiado, onde 'assume a posição de guia' e, através de tais canais, ele 'multiplcava, decuplicava, sua ação'. Entretanto, mesmo garantidas essas 'posições de influência', Alceu guardou outras esferas institucionais. É o caso de seus artigos nos grandes jornais e de seus cursos na Universidade pública, que funcionariam como uma espécie de 'tribuna' para ele. ${ }^{181}$

O primeiro passo para o lugar que ele assume no caminho de consolidação dessa posição é a definição de um trajeto, ou melhor, a identificação de um fim claro. Logo em 1929, ano seguinte ao de sua conversão e já como diretor da Ordem, o Centro Dom Vital lança um livreto de sua autoria chamado Tentativa de Itinerário. Junto com Freud e De Pio VI a Pio XI, publicações também deste ano, formam o que Villaça chama de "a primeira reflexão de convertido" ${ }^{182}$. O primeiro, contudo, é especialmente importante para se entender a posição construída por Amoroso Lima e as bases de seu pensamento, que passaria a ser consolidado nesse período.

Sobre seu Itinerário, afirma não ter a intenção de traçar um programa, conforme a premissa já defendida de que "fizeram-se os programas para o prazer de os mal cumprir". Diz traçar, antes, uma "aproximação maior com a verdade" 183. Fato é que Alceu busca construir um itinerário de análise e ação do mundo e no mundo - duas dimensões inseparáveis no pensamento amorosiano. Encara, ele mesmo o afirma, os problemas religioso, filosófico, científico, social e estético que se mostravam como as principais faces em que a questão da ação ganha contornos precisos. Parece sugerir, tácita ou explicitamente, como pode-se perceber também em outros textos e na própria organização da revista A Ordem, que a ação só pode se dar tendo em vista um corpo de análise consistente e consciente, que organize-a, seja individual ou coletivamente.

Chama atenção para um certo despertar da mocidade brasileira nos anos 1920: "Há quase meio século que faltava à mocidade brasileira aquilo que é a própria razão de ser da sua beleza e de seu prestígio: uma Causa" ${ }^{184}$. Comparando a juventude do momento com a sua própria geração, coloca a apatia - a falta de ação em função da falta de uma causa - com matizes que serão tratados ao longo desse texto e também em toda a sua obra:

Éramos filhos de uma nacionalidade que se formava (...) - entretanto carregávamos em nosso peito um coração de vencidos da vida, uma alma de desencantados e decadentes (...) Não era só, também, do abandono tremendo 
em que decorreu uma educação sem alma que nos deram nos colégios do Estado leigo - que nos sentíamos distantes. Era também por não vermos, em torno de nós, uma grande Causa decisiva a que nos entregássemos. ${ }^{185}$

Ao comparar a apatia de uma geração com a movimentação da outra, identifica esse despertar como uma tomada de consciência de uma nacionalidade que quer formar-se, identifica dois polos de ação opostos, que se apresentam como duas grandes causas, de luta e comprometimento total, aos quais os jovens podem dedicar-se e ver despertar "o gosto do sacrifício e a alegria da vitória": o comunismo e o catolicismo. E afirma: "O século XX vai ser ora um diálogo, ora um duelo, entre o Vaticano e o Kremlin, pois ambos encaram visivelmente, em face de nós, a lógica extrema do erro e a expressão intangível da Verdade" ${ }^{186}$.

A adesão a essas causas deve ser encarada como busca da nacionalidade: "É preciso tocar as raízes da nacionalidade para conhecer os perigos que estamos correndo. É preciso descer ao fundo de nossos corações para conhecermos que uma regeneração parcial não basta" ${ }^{187}$. Nessa chave, se duas grandes causas se postam frente à mocidade, só uma delas busca regenerar o mundo sob as bases da identidade e da Verdade, e era preciso decidir "se queremos ser uma nacionalidade livre e diferente, ou uma simples célula indistinta numa imensa organização econômica internacional" ${ }^{188}$.

Posta, logo na primeira parte do texto, a ligação direta entre ação e identidade - ou nacionalidade -, Amoroso Lima passa a desenvolver o ponto chave de seu itinerário.

Essa nacionalidade, essencialmente católica, seria fundamentada num passado religioso, ou seja, na memória de uma formação que confere identidade particular à luso-América, em distinção à América Anglo-Saxônica e à América Hispânica, que teriam por constituição identidades distintas. “(...) para isso afirma Alceu - é que precisamos procurar repor a civilização brasileira sobre a base religiosa em que nasceu, mas que nunca chegou verdadeiramente a ter consciência total" ${ }^{189}$. Para isso Alceu retoma uma interpretação da história nacional construída por Julio Maria,

alicerçada - como analisa Arduini - na visão do catolicismo como o único elemento gerador de uma identidade brasileira. Desse modo, para que o povo brasileiro encontrasse seu destino de grandeza, seria necessário que ele se voltasse para sua tradição e compreendesse a importância da fé. ${ }^{190}$ 
Nesse sentido, o realinhamento de Igreja e Estado sobre novas bases e a reinserção da religião na vida moderna só fazem sentido se baseados neste sentimento de fim de um tempo em que a brasilidade estivera perdida.

Ela seria justificável a partir da construção de uma imagem de crise do mundo moderno e de todos os sistemas político-econômicos já experimentados: o liberalismo, o comunismo e, posteriormente, as alternativas de extrema direita originadas na década de $1930 .{ }^{191}$

Ou seja, a ação dos católicos se baseia sobre o resgate de uma identidade e projeto de reconstrução da nação, condição para que saia do momento de incerteza e instabilidade no qual se encontrava, assim como sucedia a outros ideários que estavam em jogo. A literatura, para Alceu, deve ser resposta no "ritmo da nacionalidade" ${ }^{192}$. Através dela seria possível conferir personalidade a uma cultura sem cor, sem identidade. E essa personalidade, a seu ver, é católica.

Existe, para os espíritos livres, a necessidade de reagir contra a brasilidade forçada da literatura, que é tão falsa quanto a sua imbrasilidade. Não somos apenas formadores de nacionalidade. Não vivemos apenas integrados no meio social. Vivemos também contra ele. (...) E se uma das tarefas da nossa e da nova geração deveria ser o esforço por formar uma cultura brasileira integral. $^{193}$

A luta contra a "brasilidade forçada" e a "imbrasilidade" configuram o cerne da guerra de identidades que caracteriza a atividade do meio intelectual dessas décadas. É perceptível a necessidade, para a definição de como se dará sua atuação na sociedade, de fundamentar uma identidade que corrobore esta ação e o fim a que ela leva, definida por uma memória, cuja construção é o projeto mesmo destes homens. A circularidade destes conceitos traz à tona a necessidade de compreensão da atuação do grupo católico, assim como a dos modernistas, como uma fundamentação, em última instância, da identidade, sem a qual não se pode agir de forma efetiva.

A identidade que o grupo católico arguia estaria baseada principalmente em um passado idealizado, um outro tempo, de tradição, de um país eminentemente católico. A cristandade entendida como original, passada, é constantemente retomada na forma de uma memória de tempos áureos ou de evocação da tradição católica presente no quotidiano dos brasileiros. A perda da moral católica enquanto presença organizadora - é entendida como a base dos problemas sociais e econômicos, subordinados a ela. Uma economia refém do materialismo burguês, que ignora seus fundamentos morais, conduziria ao caos econômico e social do presente. "Devemos trabalhar realisticamente, racionalmente, cientificamente, 
mas sempre humanisticamente, por uma reforma social distributiva, contra os esquemas de mecanização comunista e capitalista que hoje se estendem pelo mundo" 194 .

À crítica ao materialismo - que se desdobra em crítica ao mundo liberal enquanto status estabelecido e à sua exacerbação, o comunismo, como direção última dele - é proposta e permite a formulação da alternativa de uma "cultura brasileira integral (religiosa, filosófica, social, política, etc.) em que se conserve ao indivíduo, ao homem todo, a sua importância fundamental de ser livre" (grifos do autor ${ }^{195}$. A crítica ao "cientismo" se dá pela defesa do espírito científico sem que ele "absorva o que não lhe pertence", causando uma "ruptura fundamental do equilíbrio de todas as ciências, pela conversão da parte ao todo", que estaria anulando as ciências especulativas em favor das ciências experimentais ${ }^{196}$.

O que está posto em Tentativa de Itinerário é a relação direta entre ação e identidade. Essa segunda, apesar de sua dimensão religiosa, é formulada de forma historicizada, remetendo a um passado fundacional. Verbos de ação como "retomar", "repor", "voltar" são centrais na operação indicada por Amoroso Lima. Essa operação, como se poderá ver, está presente em textos de outros autores que escrevem na revista A Ordem, como também aparece em autores anteriores à gestão de Alceu. O que se percebe em Amoroso Lima, contudo, é sua centralidade e, no modo como opera os diversos campos do saber, é como consolida, a partir da articulação discursiva do grupo católico, uma consciência histórica de um passado primordial perdido pela modernidade, que deve ser retomado. Essa memória constitui a tradição e, tendo sido perdida, urge ser retomada.

Pois uma das consequências fundamentais da nossa volta ao Espírito, e de nossa fidelidade ao espírito nacional característico nosso, será justamente - salvar a pessoa. Não pela volta do individualismo dissolvente e anárquico. Mas pelo estabelecimento do equilíbrio e da hierarquia no indivíduo e na sociedade. (grifos do autor) ${ }^{197}$

A própria noção de itinerário pode indicar esta articulação. Remetida etimologicamente a ideia de caminho, viagem, a ideia de itinerário remete, em seu uso, ao trajeto traçado de um ponto a outro, trajeto esse já realizado ou não. Seu significado pode nos remeter a um certo tipo de ordenação do movimento, um deslocamento através do tempo e do espaço que estava previamente traçado. Seu significado na obra inaugural de Amoroso Lima em sua fase de convertido remete a um esboço de caminho que oriente a ação ordenada a a um fim, mas que tem sua origem em um ponto muito anterior àquele da escrita do texto. Remete a própria 
formação da sociedade brasileira. Nessa articulação, a Ação - entendida como movimento - opera numa tensão entre origem e fim, articuladora da nacionalidade.

É possível enriquecer a análise da formulação de Amoroso Lima ao contrastá-la com a proposta do antropólogo Gilberto Velho. No texto Memória, Identidade e Projeto, ele aponta para a fragmentação da identidade no mundo moderno. Em uma sociedade individualista, na qual o indivíduo, agora unidade de valor básico da cultura, se vê conformado por várias identidades distintas, mas que não se encompassam necessariamente nem o definem mais por inteiro como parte de uma identidade coletiva, a memória como construção da biografia se torna central na formação da identidade, e, a partir dessa relação, possibilita uma conduta que visa a atingir certa finalidade, ou seja, um projeto. Afirma: "A consciência e valorização de uma individualidade singular, baseada em uma memória que dá consciência à biografia, é o que possibilita a formulação de projetos" 198 .

Por mais que afirme que esta relação memória-identidade-projeto só possa se efetivar com o surgimento do indivíduo-sujeito moderno, Gilberto Velho ressalta que estas categorias são elencadas também em nível social. Um dado grupo, para buscar certo objetivo, procura compreender sua identidade, o que só se dá através do recurso à memória. Pode-se buscar compreender as disputas pela identidade brasileira no meio intelectual da época a partir desse prisma. Os três conceitos se articulam de forma relacional, sem haver linha causal. Um não pode existir sem os outros dois e vice-versa. Memória como presentificação do passado e projeto como presentificação do futuro transportam, antecipam e revisitam tempos distantes e os materializam no presente. Para Velho, "O projeto e a memória associam-se e articulam-se ao dar significado à vida e às ações dos indivíduos, em outros termos, à própria identidade" 199.

Entendo, dessa forma, que a noção de itinerário presente no texto de Amoroso Lima é a articulação, ou melhor, uma proposta de articulação destas três dimensões da construção do $e u$, tendo em vista o movimento da ação. Pretendo demonstrar como o projeto nacional proposto por Alceu - na sua condição de leigo exemplar - ao propor uma discussão sobre a "personalidade" nacional ${ }^{200}$, fundamenta-se numa historicidade que articula passado, presente e futuro. Uma diferença, contudo, que se pode supor entre Amoroso Lima e Gilberto Velho, é o fato de a tríade do primeiro se mostrar de forma de certo modo hierárquica. A 
catolicidade, nesse caso, é memória fundadora, que ordena e organiza as outras duas. A ação do homem - ou da nação - que movimenta-se entre identidade, projeto e memória, é o que propõe Alceu. Este é o seu itinerário.

\subsection{As Duas faces da história}

Entre 1928 e 1934, Amoroso Lima publicou vinte e oito textos na revista, entre análises, comentários, balanços e transcrições de entrevistas, além das inúmeras referências que a Revista faz a seu nome - como autor e como líder do grupo católico. Nestes textos, seu itinerário é seguido e aprofundado através de formulações diretas e indiretas. Neles, é notória a articulação entre a nacionalidade - formulada como tradição - e os dois conceitos principais a serem analisados a seguir: História e Ação.

Ao estudar o periódico, Pimenta Velloso chama atenção para o fato de que “o passado é constantemente retomado, compreendido como 'criador de valor", e comenta:

Mannheim aborda a problemática do tempo no pensamento conservador, mostrando que o passado atinge dimensão inédita, na medida em que se altera a própria percepção da história, que deixa de ser vista como uma mera extensão unilinear de tempo, interligando passado, presente e futuro. O passado passa a ser experimentado como presente, sua presença na história torna-se, pois, uma experiência concreta.

A revista retoma o passado, não apenas com o intuito de 'salvá-lo do esquecimento', mas pretendendo torná-lo força viva e atuante no presente. A Idade Média não é apenas mencionada como um período ideal, à medida que se vislumbra uma 'nova Idade Média, já se processando. ${ }^{201}$

Para o pensamento católico, que o autor define como "reacionário" - no sentido de reação à modernidade, e sem que o conceito tenha nenhuma conotação negativa para ele -, o passado não se apresenta, contudo, não só como retomada do acontecido, mas como condição do futuro. Não à toa a partir de 1935 Amoroso Lima passa a propor a ideia de Idade Nova justamente como esse momento de reconciliação com a tradição, a partir da perspectiva aberta após as vitórias obtidas na constituição de 1934. Em seus escritos na Ordem e em outros periódicos como O Jornal, assim como em alguns de seus livros, o tema da formação nacional enquanto produtora da nacionalidade, articulado aos processos históricos mundiais, é largamente utilizado como base de toda construção intelectual e ação política e social. No início do livro Introdução à Economia Moderna, de 1933, Amoroso Lima salienta a importância da perspectiva histórica como raízes do presente: 
A perspectiva histórica é indispensável a todo estudo da sociedade humana. (...) O passado não esgota o presente, mas concorre grandemente para explicar o presente. E toda vida individual ou coletiva que aspira à estabilidade, como sucede a toda vida sadia e forte, toda ela se funda numa conexão inteligente e lúcida com as raízes do presente. A ruptura com a memória, que é o passado individual, ou com o passado, que é a memória coletiva, é sempre uma decadência definitiva ou uma euforia efêmera.

Um pouco adiante, formula ainda a forma como a relação com essa perspectiva histórica deve se dar:

O espírito revolucionário, que é sempre um pouco pueril como todo bárbaro, julga poder secionar o passado do presente. $\mathrm{O}$ espírito valetudinário, por sua vez, julga poder suprimir presente e viver apenas no perfume das grandezas mortas. Um e outro são sintomas de imperfeição ou decadência. As nacionalidades sadias, como os homens fortes, vivem também do passado, mas não vivem só no passado. E impregnar-se dessa distinção é, geralmente, um sintoma de maturidade do espírito. (Grifos do autor) $)^{202}$

A seguir, o autor apresenta uma longa discussão sobre a filosofia da História e suas formas de concepção. Põe em disputa duas formas de compreensão do movimento da história: uma retilínea, a outra circular, e faz uma análise histórica da primeira, que vê como base da sociologia positivista. Os aspectos mais relevantes são, em primeiro lugar, que o autor define com clareza sua posição no campo do que define como uma filosofia da história. Além disso, o significado que atribui ao passado como articulador do presente evidencia uma reflexão acerca de como o passado pode ser, nas palavras de Pimenta Velloso, uma "força viva" no presente e para o futuro.

Já em 1932, quando publica o livro Política, chama atenção para o perigo de uma perspectiva social meramente contratualista - voltada unicamente para o consenso no presente. Ao criticar o naturalismo sociológico de Alberto Torres, afirma que este autor, ao repudiar "o 'passado', a 'raça', a 'família', como elementos formadores da nacionalidade brasileira", estaria "trabalhando em benefício dos nossos piores inimigos. Querendo nacionalizar a nossa pátria, não fazia mais que desnacionalizá-la (...)" ${ }^{203}$. A relação entre a dimensão do passado e a nacionalidade formula-se a partir da ideia de hereditariedade, assim como outros fatores como família e raça. Este último, segundo o autor, voltava à centralidade do debate com a expansão dos estudos "racistas alemães e com o movimento eugenista nos Estados Unidos" 204.

Em seus textos na revista A Ordem a importância da perspectiva histórica na análise do presente fica ainda mais visível. Em um de seus escritos mais famosos, o autor justifica sua conversão na chave de uma reconciliação com esta 
tradição. Em "Adeus à Disponibilidade" (1928), ele responde em carta aberta as críticas feitas por Sérgio Buarque de Hollanda em relação a sua conversão. Sérgio sustentava que a opção pelo pensamento católico seria limitadora da liberdade intelectual, Alceu afirma, em resposta, que "o amor da evasão pela evasão é a pior das escravidões" ${ }^{205}$, e que a opção significa o engajamento em um mundo que não aceita mais o diletantismo intelectual. À liberdade da opção é oposta uma escravização ao processo histórico que identifica.

No momento em que a ciência mostrara que era necessário arrancar quanto possível de nossas concepções o erro geocêntrico, a filosofia nos arrastava toda ela a construir os nossos sistemas sobre um erro homo-cêntrico. ${ }^{206}$

$\mathrm{O}$ erro da modernidade é visto por Alceu como um processo de afastamento e como um equívoco fundamental do pensamento. Argumenta que sua conversão representa um comprometimento com o mundo em seu sentido amplo e que, nesse sentido, é uma busca da plenitude, ao invés de uma restrição. Ao contrário, afirma que o alheamento e a romantização da negação, essas sim, são limitadoras. Mostra ainda, como o pensamento de Sérgio Buarque está banhado da doutrina cristã, e que a tentativa de fugir disso é a verdadeira limitação. Como exemplo, cita um trecho de um ensaio de Sérgio sobre Thomas Hardy, e finaliza o texto dizendo que

os caminhos da vida não nos separam. E eu confio profundamente no sentido, que V. tem, do que há de trágico na Verdade. (...) Quem escreveu essas linhas é que compreendeu até onde vai a sombra da Cruz. E é por lá que nos encontraremos. ${ }^{207}$

O que pretende demonstrar, em síntese, é o quão profundamente se estende a dimensão cristã da formação da cultura brasileira. Ao atentar para a consciência de Sérgio Buarque da "tragédia cristã", a afirmação não tem caráter unicamente individual. O sentido da afirmação de Alceu, mais amplamente, é demonstrar como a tradição cristã é inescapável, pois está profundamente arraigada em nossa nacionalidade.

A percepção histórica de Amoroso Lima pode ser entendida de duas formas que encontram paralelo na própria noção de tempo da cristandade. Quando se refere ao passado, sua escrita sublinha sempre duas dimensões: de um lado, o caráter processual do caminho da humanidade, com seus movimentos, suas cisões, suas glórias. Nessa perspectiva, situa a Igreja no processo temporal como um de seus atores, e a humanidade é analisada a partir de sua proximidade ou afastamento da Verdade. Por outro lado, ao construir o que Guilherme Arduini chama de "hagiografias modernas" 208, o caráter histórico se reveste da sua dimensão de exemplaridade própria dos santos e dos homens fortes. Ao processo 
histórico é confrontada a atemporalidade dos homens de Deus que marcaram a história da Igreja, como Anchieta e Dom Vital. Se a primeira dimensão mostra o afastamento que a modernidade tomou da Verdade cristã, a segunda deve servir de modelo para a ação dos homens em qualquer momento.

Essa dupla face da historicidade pode ser melhor compreendida através da própria tradição cristã. Segundo Marcelo Timotheo da Costa, o tempo na tradição cristã se divide em dois: Aeternitas e Tempus $^{209}$. O primeiro indica a simultaneidade total, o caráter estático da transcendência, em que tudo subsiste. $\mathrm{O}$ segundo, associado à precariedade, é a dimensão da mudança, da morte, do movimento. Normalmente a hegemonia da visão tridentina na Igreja católica, prevalente no período estudado, é associada a uma visão atemporal da Igreja, em oposição ao aggiornamento da década de 1960, no qual a Igreja - e nela o próprio Alceu - se associa a uma ideia de religiosidade móvel e em transformação. Essa posição, defendida por Marcelo Timotheo, apesar de pertinente, não leva em conta o processo de construção da consciência histórica do pensamento católico no período aqui estudado. Apesar de associado a uma "Verdade" eterna, na qual a exemplaridade dos homens santos é trazida para o presente através da rememoração, da santificação, das comemorações, das festas litúrgicas, da hagiografia, subsiste desde a encíclica Rerum Novarum a perspectiva de que as ações da Igreja se dão no processo imanente do tempo, e que esse tem movimentos coordenados. Mesmo não conferindo um sentido, um telos imanente ao processo histórico, Amoroso Lima o considera como um corpo que assume direções e movimentos coordenados ao longo do tempo.

Primeiramente, é preciso entender como Alceu identifica as bases católicas da nacionalidade não a partir de uma interioridade eterna, mas a partir do processo histórico de formação nacional. No texto Traços da Psicologia do Povo Brasileiro, ele afirma que a formação de um Estado forte depende da capacidade de seu povo de criar uma "Nacionalidade Viva" ${ }^{210}$, e condiciona essa criação à condição de "não trair seu passado católico (...) se não trair a espiritualidade da sua alma" e conclui que o Brasil "só será universal se nunca deixar de ser brasileiro" ${ }^{211}$. A relação entre universalidade e brasilidade chama a atenção. Após uma esquematização sistemática e alongada sobre as diferenças internas da constituição do povo - oposições litoral/sertão, cidade/campo e norte/sul - o autor 
afirma que a formação eminentemente católica é a única coisa que une e que pode unir a nacionalidade brasileira, tão ampla e múltipla.

Do ponto de vista moral e religioso ainda mais eloquente seria a lição dos fatos. Cristão nasceu o Brasil, cristão educou-se. Cristão cresceu. E os erros da sua formação ou da sua alma derivam sempre do esquecimento momentâneo desse fato fundamental da sua história, sem o qual se torna ininteligível o estudo e a compreensão da psicologia brasileira.

E ainda conclui que "todos os traços que hoje encontramos no que denomina a psicosíntese do povo brasileiro, são derivados de sua formação religiosa" ${ }^{212}$. A dimensão da formação religiosa é o elemento centrífugo no qual a brasilidade ganha a dimensão de uma nacionalidade em formação.

Em texto publicado n'O Jornal em outubro de 1930, intitulado “Formação do Brasil", Alceu faz a crítica do livro A Formação Espiritual do Brasil, de Batista Pereira, que através da "síntese histórica, o que se entende é o desejo de procurar a nossa unidade psíquica, aquilo que já somos em essência" ${ }^{213}$. Ao fím do texto, está em plena concordância com o autor quando explica que

Estudados depois os elementos iniciais de nossa raça em formação, o luso, o índio, o negro, sempre com pontos de vista originais e próprios - passa o A. a ressaltar a importância fundamental que tiveram os jesuítas em nossa formação e o desastre que foi a pombalisação em nossa vida espiritual. Pombal foi o grande traidor das raízes tradicionais da cultura luso-brasileira. Foi ele que desvirtuou a nossa evolução histórica. Foi ele que envenenou as fontes da nossa vida espiritual, corrompendo de enciclopedismo o ensino em Coimbra e contaminando o espírito brasileiro (...). As anomalias de nossa vida religiosa que são um dos elementos mais perniciosos para a saúde moral de nossos homens e para a afirmação da própria nacionalidade, derivam sobretudo dessa fonte: o confusionismo pombalino que se extravasou no confusionismo brasileiro. ${ }^{214}$

Essa visão da ruptura pombalina no fim do século XVII reforça em Alceu a ideia do século seguinte como o auge do materialismo moderno. A análise do corte na vida religiosa com o Marquês de Pombal foi formulada de modo mais aprofundado pelo padre Júlio Maria em $1900^{215}$. Em seu livro já citado, ele formulará a história da formação brasileira à luz do primado do catolicismo. A aproximação entre as obras de Júlio Maria e de Amoroso Lima acerca da nacionalidade é constante nos estudos sobre Alceu, como já foi observado. Tanto o padre como o leigo veem na formação da colônia portuguesa no Brasil uma junção entre religiosidade e identidade coletiva, que, para ambos, constitui a "nacionalidade" e é a partir da formulação histórica da primeira que boa parte do catolicismo brasileiro irá se basear. 
$\mathrm{Na}$ introdução de seu livro A Igreja e a República, Julio Maria indica a característica principal dos três períodos históricos que distingue: o período colonial, o Império e a República.

No primeiro, a religião e o descobrimento das terras brasileiras se confundem num só fato histórico; e a primeira missa, a posse divina, o jesuita são os três mais belos episódios do drama grandioso que o cristianismo veio representar nesse cenário americano. ${ }^{216}$

No período imperial, "apesar do profundo sentimento católico que anima o povo e do prestígio que ela tem para as massas", o regalismo, o desprestígio do clero e o enfraquecimento das ordens religiosas marcam a Igreja. A proclamação da República viria para marcar um período de possibilidades, em que o afastamento do Estado, ao passo que retira o elemento religioso da esfera do governo, dá mais liberdade à Igreja e às suas ordens religiosas ${ }^{217}$.

Seu livro é dedicado a demonstrar dois fatos principais: a formação da nacionalidade a partir da religião, na colônia, e a perda dessa identidade no império, dando continuidade à política pombalina portuguesa. Com uma análise histórica de natureza ensaística, Júlio Maria se baseia nas políticas e práticas de jesuítas, franciscanos e outras ordens que posteriormente vieram às Américas para construir uma leitura histórica que articula a formação das primeiras comunidades à formação de um pensamento religioso na colônia associado ao contato com os índios. Por isso a "ação do jesuíta no período colonial, onde a sua missão pode ser considerada sob tríplice ponto de vista: a obra humanitária foi a defesa do indígena; a obra política, a tentativa de formar uma nação aborígene; a obra católica, a catequese" ${ }^{218}$. As posteriores tensões entre os jesuítas, associados aos índios, e os portugueses bandeirantes, com o apoio dos negros escravizados, seria o vislumbre do embate entre dois projetos diversos de colonização. Porém, ele afirma que este primeiro projeto, jesuíta, que se firmou aqui em todos os primeiros assentamentos muito antes da colonização efetiva da coroa, firmou bases culturais e religiosas profundas. "Foi à sombra da Cruz que se formaram os nossos costumes, se promulgou o nosso direito, se legislaram os nossos códigos, se formou a nossa nacionalidade" 219 .

Essa identificação direta entre a ação jesuíta no interior da colônia e a formulação do aspecto eminente brasileiro da formação nacional é de tal intensidade que não se pode eliminar o jesuíta "de nossa história sem suprimir as origens da pátria", pois foi ele "o vexilário de nossa existência" ${ }^{220}$. Essa obra 
jesuíta só foi destruída realmente a partir de Pombal e, depois, da instauração do padroado como política de Estado. Isso trouxe à Igreja e ao clero, atrelados ao Estado, uma apatia imensa. Essa apatia só teria sido quebrada por Dom Vital, “o primeiro bispo que tentava a reforma da Igreja Brasileira", segundo esse autor, sobre suas verdadeiras bases de esplendor, em momentos de decadência ${ }^{221}$.

A relação entre a descoberta das américas e o resto do mundo, contudo, na obra de Júlio Maria, se daria de maneira forçada e por demais providencial em relação ao pensamento de Amoroso Lima. Associando a colônia nas Américas ao esplendor da Idade Média, sugere que o descobrimento daquelas se deu como que por compensação divina às perdas que a Igreja sofrera na Europa com a Reforma.

Alceu, por sua vez, relaciona mais profundamente os processos do pensamento religioso no Brasil aos movimentos da história geral e europeia. É preciso chamar atenção para uma diferença profunda entre as duas obras. Enquanto Júlio Maria tem em mente uma história factual e associada aos eventos concretos - como as missões jesuítas, os enfrentamentos com os bandeirantes etc. -, Alceu traça a história da humanidade com base principalmente na história do pensamento. A história da filosofia ocidental muitas vezes é tomada como o curso da história da humanidade sem que haja uma diferenciação entre as formulações intelectuais e os homens comuns. Os processos históricos são vistos constantemente sob a ótica dos debates intelectuais que expressam, não como indícios mas como estopins de um movimento maior da humanidade.

Nas sua leitura do processo histórico Alceu percebe o progressiva afastamento do mundo em relação à espiritualização alcançada durante a Idade Média $^{222}$. Afirma que

os movimentos da Reforma, no século XVI, do Cartesianismo, no XVII, da Enciclopédia, no século XVIII e finalmente das ciências experimentais no século XIX, abriram para o pensamento oportunidades certas ou ilusórias jamais suspeitadas, - em face dessas exigências encontrou-se até certo ponto desprevenido o pensamento cristão. ${ }^{223}$

Nessa perspectiva, o processo histórico teria como problema principal o da "racionalidade da fé":

Todo o pensamento modernista, religioso ou não, se vem jogando contra ela desde que Lutero iniciou o livre exame religioso e Descartes o livre exame especulativo. Todos os adversários da Fé, sejam quais forem as suas divergências entre si, se encontram sempre nesse terreno comum: à ciência a razão, à fé o sentimento. As modalidades de objeção podem ser infinitas, mas o fundamento é o mesmo. ${ }^{224}$

A leitura de Amoroso Lima sugere que a formação do que seria para ele a nacionalidade brasileira nas Américas é um dos últimos refúgios da era de ouro da 
escolástica, na Baixa Idade Média, antes que a modernidade iniciasse o processo de afastamento progressivo da Verdade. Além das causas que afetam todos os povos ao redor do mundo, afirma, no Brasil "foi exatamente essa hipertrofia da afetividade religiosa, provocada pelo liberalismo do século passado e sobretudo pela ignorância doutrinária em matéria de religião" ${ }^{225}$ que provocou essa cisão. $\mathrm{O}$ lento progresso do materialismo moderno se dá nessa fratura entre fé e razão, que os católicos buscam reabilitar.

Não havendo estudos superiores de religião para leigos, nem mesmo estudos secundários, ficando a religião apenas no período da escola primária e isso mesmo graças ao esforço privado das famílias ou dos religiosos - não havendo, portanto, cultura religiosa, a fé refugiou-se apenas no coração, no melhor dos casos. ${ }^{226}$

A esse problema urge uma solução: "vivificar a cultura, fundi-la em nossa realidade nacional e pessoal" 227.

A visão do processo histórico de Alceu se aproxima daquela de outro intelectual seu contemporâneo que, ainda que levante a bandeira católica, não faz parte do grupo de leigos ligados à hierarquia católica. Principal articulador político e intelectual do Integralismo, a partir de 1932, Plínio Salgado também vê na re-espiritualização do mundo um meio de reatar esse "Sentimento de Nacionalidade" 228 de origem na sociedade espiritualizada formada na colônia portuguesa na América. Também ele vê na expansão do "pensamento racional" na modernidade a propagação do materialismo e a queda da experiência de mundo total e transcendente.

As chaves de leitura da história de Plínio Salgado são próximas das de Alceu, e em sua crítica ao capitalismo usa das mesmas premissas de secularização do mundo. Segundo Ricardo Benzaquen:

(...) o materialismo e o espiritualismo vão funcionar, na doutrina de Plínio, como verdadeiras Chaves da História, quer dizer, como conceitos em condições de explicar qualquer situação ou evento, em todos os momentos e lugares, sem precisar, inclusive, fazer nenhuma alteração no seu sentido ou na sua moralidade inicial. (...) por mais longe que você vá na particularização, na caracterização da sua análise, o segredo desta estará sempre contido na oposição entre materialismo e espiritualismo. (grifos meus) ) $^{229}$

O palco das "grandes realizações da humanidade monoteísta" ${ }^{230}$, a Idade

Média europeia, cede espaço à desespiritualização do mundo. A articulação entre o universal - reduzido à história europeia - e o nacional é feita de maneira mais sutil e integrada. Progressivamente o desenvolvimento do capitalismo, enquanto força social dessa racionalidade materialista, influenciaria os caminhos da sociedade brasileira. Em editorial de janeiro de 1933 - cuja autoria, como em 
outros editoriais, para é possível atribuir a Alceu - Amoroso Lima afirma que não se pode traçar uma linha única em que se confundam o ritmo religioso e o ritmo histórico. Contudo, a comparação continua sendo válida para explicitar com que tipo de mentalidade crítica o autor lê o processo histórico.

Diferentemente de Plínio, que a partir de sua visão do processo histórico propõe uma ação revolucionária de caráter incendiário, Amoroso Lima vê na reabilitação da escolástica enquanto força intelectual um dos pontos centrais da recristianização do mundo. A articulação entre razão e fé, tão perfeitamente integrada na filosofia de Tomás de Aquino, deve ser retomada, como sugere o Papa na encíclica Aeterni Patris. "Podemos afirmar que o realismo crítico de Aristóteles e Santo Thomas (sic) oferece talvez a única oportunidade séria de se tentar uma grande síntese integral do pensamento filosófico antigo, medieval e moderno" ${ }^{231}$. Tomismo e Idade Média são relacionados diretamente, na chave da junção entre filosofia e processo histórico mencionado anteriormente. A proposta da adoção de uma neo-escolástica que aproxime a doutrina tomista às questões contemporâneas surge como a própria condição de possibilidade da neocristandade. A reconsideração dos problemas filosóficos à luz desta doutrina é expressa sob o prisma do "encadeamento sucessivo do pensamento das gerações, que Descartes ou Spinoza tentaram quebrar pela atomização da pesquisa filosófica" ${ }^{232}$. Se essa síntese for atingida, os descaminhos da modernidade tornar-se-iam meros acidentes no caminho maior da filosofia cristã.

Uma voz de reabilitação da tradição que surge em meio à tradição filosófica, segundo Alceu, é Jackson de Figueiredo. No artigo "Seu Lugar", de 1929 (único que assina com seu próprio nome, e não com o pseudônimo Tristão de Athayde), ele insere o pensamento do seu mestre do quadro da história da inteligência brasileira até aquele momento:

A inteligência brasileira, no século XIX, partira de um espiritualismo eclético, recebido de Victor Cousin. Passara depois ao naturalismo evolucionista de Tobias Barreto e Sylvio Romero (sic) e ao positivismo anti-metafísico do início da República. E desse naturalismo se dividira em outras duas grandes correntes: o ceticismo agnóstico, sob influência de Machado de Assis, aqui, e de Anatole France e Eça de Queirós, fora daqui, e o espiritualismo subjetivista de Farias Brito e o simbolismo. ${ }^{233}$

Jackson busca condensar as três grandes tendências do pensamento brasileiro no século anterior: materialismo, espiritualismo e ceticismo, para depois ultrapassá-las por meio da "Síntese Católica" ${ }^{234}$. Essa síntese, que supera o 
espiritualismo incompleto por utilizar o melhor das três tendências, buscando uma verdade mais larga e mais profunda, é o seu legado. "O seu segredo foi mostrar, talvez, que havia essa face de verdade no materialismo, no espiritualismo e no ceticismo e que nenhum deles era puro erro" ${ }^{235}$.

A importância de situar historicamente a figura de Jackson na inteligência brasileira mostra um cuidado com a inserção do pensamento católico - o que se compreende como herdeiro de Jackson - dentro de um processo em que o binômio ruptura-continuidade se afirma. A síntese católica é o novo que supera o "novo" incompleto, ao mesmo tempo que faz isso recorrendo à tradição. Esse binômio posto em cena leva à ideia de superação presente no conceito de "síntese". Remetendo a uma forma de elevação, a síntese não se apresenta como mais um elemento do debate, mas se lança como a transcendência do plano do debate para a reconciliação de todos sob a égide da Verdade. Essa operação será muito comum no pensamento católico.

O artigo ao qual me refiro se encontra na edição especial da Revista lançada em março de 1929 em homenagem e memória de Jackson de Figueiredo, uma "homenagem definitiva que tantos espíritos ilustres do Brasil contemporâneo prestam à memória inesquecível do nosso fundador" ${ }^{236}$. Contando com textos de inúmeras personalidades literárias da época que iam de Dom Sebastião Leme e Leonel Franca a Graça Aranha, Sérgio Buarque de Holanda e Ronald de Carvalho, o volume, múltiplo e polifônico, se converte em uma verdadeira hagiografia. A intenção de inserir Jackson no panteão de homens notáveis da Igreja se mostrava com toda força na construção de sua memória e se realiza sob alguns consensos: a modernidade incontestável do autor sergipano, sua profundidade filosófica e sua importância na superação de certas correntes do século XIX. Esse esforço de construção memorialística dialoga com as frequentes "hagiografias contemporâneas" de que fala Guilherme Arduini. Tais produções consistem em trabalhos aprofundados sobre figuras recentes que serviriam de "modelo intelectual e religioso" não só para o autor mas para o público ${ }^{237}$ e se constituem na construção de um panteão de homens fortes da Igreja. Tais hagiografias tomam a forma da biografia dos santos, e reproduzem inúmeras de suas características.

Por mais que Alceu não se aprofunde, em seus textos, em biografias específicas, esta dimensão hagiográfica da exaltação de homens importantes, sejam eles santos reconhecidos pela Igreja, sejam leigos recentes, está presente em 
seus escritos. Além da constante exaltação da figura e da memória de Jackson, o anúncio da morte de Felício dos Santos também ganha certo sabor hagiográfico. Ao afirmar que, superando seu materialismo científico, "seu amor ao fato não podia deixá-lo alheio ao maior fato da História: a revelação cristã e a Igreja que até hoje a defende em suas linhas integrais" ${ }^{238}$, Amoroso Lima traz implícita a dimensão trágica presente na impossibilidade da negação do fato religioso. Construindo um certo panteão da ação católica no Brasil, convoca a memória de Carlos de Laet, Jackson de Figueiredo e Felício dos Santos como os "três nomes da apologética no Brasil" ${ }^{239}$.

A Comemoração de Anchieta, texto de 1934, indica também o papel da exemplaridade na temporalidade amorosiana. Lançado no número em homenagem a José de Anchieta, padre jesuíta de importância central no período colonial, lembrado como o principal religioso a aproximar-se dos povos nativos - e autor da mais importante gramática tupi na época -, o texto direciona seu foco para a importância da atualização dos santos enquanto modelos nos nossos tempos. As comemorações justas "revivem figuras esquecidas, atualizam os heroísmos passados e estabelecem a verdadeira continuidade moral entre as gerações" ${ }^{240}$. A dimensão da exemplaridade fica clara quando afirma que

a grande força da Igreja católica está justamente em aliar, constantemente, o culto de seus santos passados à procura incessante de novas formas de santificação (...) [para que possamos fazer] o que eles fizeram, em nosso meio e tempo. ${ }^{241}$

Outros exemplos, como o de São Francisco de Assis, surgem por vezes carregados dessa dimensão da exemplaridade, não só nos textos de Alceu. A afirmação da continuidade, da eternidade presente nos grandes feitos dos santos ganha uma dimensão temporal diversa daquela do processo histórico da humanidade. Mesmo reconhecendo a necessidade de atualizar a ação desses homens no presente, seu caráter supratemporal é enfatizado.

Essa perspectiva está também presente nos escritos de Júlio Maria. Contudo, ao escrever sobre Anchieta e sobre o padre Manuel da Nóbrega, ele os define como "as duas mais completas e belas personificações do jesuíta no período colonial do Brasil, que a Companhia encheu de falanges intrépidas e heroicas" ${ }^{242}$. Apesar de serem qualificados como "heróis da nacionalidade" e "figuras excepcionais" ${ }^{243}$, sua importância se verifica por representarem centenas de outros atores anônimos que empreenderam o mesmo trabalho. A diferença do Anchieta de Júlio Maria para o Anchieta de Alceu é clara: enquanto o primeiro é 
personificação do grupo, o segundo se destaca e alça-se à eternidade como personalidade singular. A exemplaridade de Júlio Maria é temporal, a de Alceu é pautada pela eternidade e imutável.

Essa exemplaridade carrega em si o sentido da espiritualidade, que para Alceu se confunde com o sentido da nacionalidade. O exemplo, portanto, conduz a ação no terreno da identidade por meio dos caminhos já trilhados e aponta uma certa pragmática. Não à toa, Amoroso Lima associa a recristianização dos nossos tempos com a cristianização empreendida por Anchieta, e chama atenção para as três modalidades de catequese anchietanas: "caridade, ensino e pregação" 244.

As duas faces da história encarnam as duas faces do tempo cristão: Aeternitas e Tempus e se traduzem em exemplaridade e processo no pensamento amorosiano. Permanência e movimento, manutenção e decadência, solidez e efemeridade. As duas dimensões se completam para que se possa entender a ação no tempo presente como produto desse duplo jogo historicista. As faces da moeda estão estampadas, resta saber como lançá-la.

\subsection{Os dois caminhos da ação}

Amoroso Lima foi chamado inúmeras vezes para discursar em turmas de formandos. Tendo recebido ao longo de sua vida, muitas vezes, a honra de ser paraninfo, seus discursos de formatura se amontoam quase como um gênero próprio que cultivou ao longo da vida. A constância com que era chamado para discursar, já na década de 1930, indica o quão errado estava quando disse a Sérgio Buarque de Hollanda que com sua conversão arrancava de si "as últimas veleidades de influir sobre "a nossa geração e o nosso momento", ${ }^{245}$. Os discursos de paraninfo eram um meio eficaz de falar diretamente à juventude que ali estava, materializada em sua frente, em uma relação de admiração já estabelecida. Tais palanques eram uma importante frente de ação.

E é desse tema que Alceu fala em um desses discursos, publicado em novembro de 1933 no número quarenta e um da revista A Ordem, sob o título de "Oração de Paraninfo". Em sua fala, no momento em que completam-se vinte e cinco anos de sua formação no Ginásio Nacional, tal como passara a chamar-se o Colégio Pedro II na República, ele percebe como as mudanças ocorridas nesse meio tempo oferecem à nova geração possibilidades mais amplas de ação e de influência no mundo. “O que nos ensinaram era que o 'homem' nada podia contra o determinismo cego da natureza e da história, pois a sua alma não era livre, nem 
a sua vontade capaz de mudar o curso fatal das coisas" ${ }^{246}$. Esse alheamento da influência e da vontade do homem frente ao arrebatamento do mundo, ao longo desses vinte e cinco anos, havia sido deixado para trás. Para ele, a sensação burguesa de que a ação liderada pela vontade não tem efeito social estava sendo a cada dia desmantelada por novos exemplos. Um deles era o de Hitler, que havia subido ao posto de chanceler do governo alemão naquele ano sob uma bandeira fortemente nacionalista, que Alceu vê como a evidência de que a "vontade de um homem vencera a anarquia e o destempero de uma nação e de um homem que conseguia inflamar a alma de um povo" ${ }^{247}$. Este e outros exemplos têm em comum o fato de um homem que se afirma ao retemperar a alma da nacionalidade.

A simpatia com que Amoroso Lima e outros intelectuais católicos viam o surgimento dos fascismos na Europa da última década se dava exatamente por seu caráter nacionalista e do fato de que a ação, baseada na nacionalidade - seja o nacionalismo racial alemão ou a nacionalidade trabalhadora italiana - pudera derrubar os anacrônicos regimes burgueses agonizantes que, dizia, viam seus últimos dias.

Esse cenário mundial possibilitou um clamor pela ação enquanto forma efetiva de mudança social: "Entrais na mocidade com um duplo dever a cumprir: afirmar a vossa personalidade e ser fiel à alma do povo". Essa alma do povo, presente em cada brasileiro, é a base de toda ação bem sucedida. "Temos, sempre, como filhos de um grande povo, as qualidades da alma coletiva da grande pátria e, além disso, as da nossa pequena pátria, da região em que nascemos (...)" 248.

Essa associação perpassa toda a produção de Amoroso Lima neste período, bem como boa parte da produção católica. Sua ação deve estar profundamente fundamentada na alma do povo para que seja profícua, para que possa efetivamente ser motor de mudança. Ao final do discurso, ele proclama: “(...) guardai, bem fundo no vosso coração, a certeza de que o homem pode governar os acontecimentos, mas que só o fará se for fiel à alma do seu povo (...)" 249.

Ao traçar as formas de ação que o pensamento de Alceu, em diálogo com o seu contexto, constrói, é necessário fazer uma análise que extrapole a letra do texto e entenda os movimentos que circundam as ideias que se apresentam. Por isso, se no tópico anterior a relação das formulações de Amoroso Lima com as de intelectuais passados e presentes auxiliou na compreensão mais ampla do que ele entendia como História, agora essa amplitude se dá pela relação entre a dimensão 
que a ação carrega nos textos e os acontecimentos contextuais. Somente assim seria possível compreender o sentido maior que subjaz às ideias em disputa.

Essa ação, em princípio difusa e de caráter cultural por demais abrangente nos textos de Alceu, vai ganhando concretude e consciência a partir da revolução de 1930. Em "O Anjo da Escada e os Professores" de 1929, o impacto da retomada do tomismo como corrente filosófica central é apresentado como o principal meio de ação cultural para recristianizar a sociedade. Após a tomada de poder de 1930, em dezembro, A Ordem publica um texto assinado por Tristão de Athayde com indicações para os católicos sobre as formas reagir politicamente aos acontecimentos que se desenrolavam. O período pós-1930 traz a sensação de um campo de disputa aberto ao futuro, em parte pela falta de conteúdo político programático da revolução varguista. A possibilidade de fundar uma nova relação entre o governo e a Igreja é precedida, nos textos, pela necessidade de fundar uma nova relação entre Estado e Povo. "Precisamos é trabalhar para que (...) os princípios básicos da ordem social cristã venham de novo informar a nossa Constituição política" ${ }^{250}$.

O primeiro passo foi apresentar seis reivindicações para uma possível constituinte a se formar, passo já explicitados no capítulo anterior. A década de 1930 trouxe, além da mudança de tom da Ação Católica, mudanças expressivas na trama política e no tecido social do país. O prestígio de Dom Leme permitiu que assumisse uma posição conciliadora por ocasião do golpe de Vargas, acompanhando o presidente Washington Luís para fora do Palácio presidencial, cercado pelos revoltosos. Acabara de se tornar cardeal, por ocasião da morte de Joaquim Arcoverde, e exerceu importante papel de legitimação do poder e de articulador de questões sociais a partir de sua aproximação com o então líder do governo provisório.

Um dos eventos cruciais na formação deste novo governo é a Constituinte de 1934, que formularia as bases da nova política. A Liga Eleitoral Católica (LEC), fundada em 1932, tinha como objetivo a organização dos católicos tendo em vista a representatividade do grupo na constituinte. Após a derrota significativa na reforma constitucional do governo Artur Bernardes em 1924-26, o laicato percebeu a necessidade de se organizar melhor, a partir de um polo único, para garantir que suas reivindicações fossem atendidas. Assim, a LEC se preocupou com reforçar nomes de seu interesse para ter certeza que suas 
propostas fossem defendidas. Seguindo à risca a instrução do cardeal Leme, que desaconselhara a formação de um partido católico, a LEC funcionava como uma organização à parte, que procurava firmar parcerias e compromissos para eleger os candidatos de sua escolha para a assembleia constituinte. A atuação da Liga foi expressiva Dom Isnard afirmou que Amoroso Lima "do lado de fora trabalhou talvez mais do que qualquer outro do lado de dentro" ${ }^{251}$. A perspectiva da constituinte como foco de disputa da reformulação do Estado tem lugar central na perspectiva de ação católica, e Alceu entendia isso.

Dois aspectos podem ser ressaltados como principais na pauta do laicato católico e do povo, por extensão. Guilherme Arduini atenta para a "complementaridade entre o projeto educacional e o de organização das classes operárias" 252 .

Enfim, era chegada a hora de "recuperar o Brasil para Cristo", especialmente por meio de duas classes: o operariado, que deveria ser disciplinado dentro dos sindicatos católicos, e as classes intelectuais, cuja elevação moral deveria ser garantida pela ampla propaganda da doutrina católica. ${ }^{253}$

Estes dois polos, que são também os polos de ação do Centro Dom Vital e da Ação Católica, serão articulados e propostos para um amplo debate principalmente nos anos que precedem à constituinte. Subitamente, questões de caráter abstrato ganham a possibilidade de concretude com o governo provisório, e por isso a organização de frentes de luta social se fazem necessárias.

No texto "Tríplice Decálogo", de 1932 - uma entrevista ao jornal O Globo transcrita na revista -, Alceu propõe o que seria um Estado Ético-Corporativo que tivesse como unidade básica a família e como base política e social o sindicato, através do qual a doutrina católica assumiria um lugar de articulação. Desenvolve sucintamente, na forma de vários tópicos, as principais preocupações para a formação deste Estado, apresentado como a solução em lugar dos inúmeros modelos fracassados - liberalismo, socialismo, nacional-totalitarismo. Constrói seu argumento para a "regeneração nacional" sobre três pilares: a ordem política, a ordem econômica e a ordem espiritual ${ }^{254}$. A partir dessa organização imaginada por Alceu - que seria mais desenvolvida no texto No Limiar da Idade Nova, de 1935, o Estado assume seu papel ético, fundando-se na "moral absoluta, racional e sobrenatural, à sombra da qual se fez o Brasil e a cujos postulados se submete, fielmente, ainda, a grande maioria do povo brasileiro". Ao Estado cumpre "reatar, com prudência progressiva, e em obediência à razão e à vontade da maioria da 
Nação brasileira, as tradições da nossa vida pública, tão imprudentemente interrompidas pela constituição federal (sic)" ${ }^{255}$. A representatividade seria construída através de sufrágio em parte universal, em parte de ofício. Assim, ganhariam proeminência as corporações, cujas bases seriam os sindicatos e que teriam a presença de figuras religiosas, como acontecia nos círculos operários católicos que naquele ano começaram a surgir.

A Organização do Estado Ético-Corporativo por Amoroso Lima chama atenção da centralidade da família e do sindicato como unidades básicas da vida social, sendo elas a base de organização encadeada de todo sistema. A religião carregaria não só a dimensão da redenção, mas neste caso específico funciona mais como meio legitimador da reaproximação do Estado e suas origens. Esta organização, assim como os círculos operários católicos, está baseada em fundamentos bem anteriores.

A encíclica Rerum Novarum é um dos documentos fundadores da restauração católica em 1891. Nela, o papa Leão XIII toma um passo de atualização das questões religiosas, preocupando-se com as relações da Igreja com a modernidade, quando lança uma encíclica sobre as "coisas novas". Neste caso, era evidente que a questão social era inadiável, e que da Igreja se esperava o engajamento crítico no mundo moderno.

É por isto que, Veneráveis Irmãos,(...) Nos pareceu oportuno,(...), falando-vos da Condição dos Operários. (...) O problema nem é fácil de resolver, nem isento de perigos. E difícil, efetivamente, precisar com exatidão os direitos e os deveres que devem ao mesmo tempo reger a riqueza e o proletariado, o capital e o trabalho. Por outro lado, o problema não é sem perigos, porque não poucas vezes homens turbulentos e astuciosos procuram desvirtuar-lhe o sentido e aproveitam-no para excitar as multidões e fomentar desordens (sic). ${ }^{256}$

A encíclica dá um passo importante ao reconhecer a questão social como um problema a ser tratado pela Igreja. Recusa a solução do socialismo e do conflito, e por todo o texto propõe formas de chegar à harmonia e à cooperação entre as classes.

Sobre a relação da Igreja com a questão social, afirma que:

a questão de que se trata é de tal natureza, que, se não apelamos para a religião e para a Igreja, é impossível encontrar-lhe uma solução eficaz. Ora, como é principalmente a Nós que estão confiadas a salvaguarda da religião e a dispensação do que é do domínio da Igreja, calarmo-nos seria aos olhos de todos trair o Nosso dever. Certamente uma questão desta gravidade demanda ainda de outros a sua parte de atividade e de esforços; isto é, dos governantes, dos senhores e dos ricos, e dos próprios operários, de cuja sorte se trata. Mas, o que Nós afirmamos sem hesitação, é a inanidade da sua acção fora da Igreja. E a Igreja, efetivamente, que haure no Evangelho doutrinas capazes de pôr termo ao conflito ou ao menos de o 
suavizar, expurgando-o de tudo o que ele tenha de severo e áspero; a Igreja, que se não contenta em esclarecer o espírito de seus ensinos, mas também se esforça em regular, de harmonia com eles a vida e os costumes de cada um; a Igreja, que, por uma multidão de instituições eminentemente benéficas, tende a melhorar a sorte das classes pobres; a Igreja, que quer e deseja ardentemente que todas as classes empreguem em comum as suas luzes e as suas forças para dar à questão operária a melhor solução possível; a Igreja, enfim, que julga que as leis e a autoridade pública devem levar a esta solução, sem dúvida com medida e com prudência, a sua parte do consenso.

Não luta, mas concórdia das classes (sic). ${ }^{257}$

O reconhecimento da questão operária como central para a Igreja católica pode ser visto também na obra do Padre Júlio Maria, que afirmava que o dever de todo católico era "pôr em prática o programa que Leão XIII, para todas as situações idênticas à nossa, resumiu numa frase - aceitar o direito constituído $e$ combater a legislação" 258 . O padre afirma reiteradamente que o dever dos católicos é a reaproximação entre Igreja e povo. Diz ser dever do católico, principalmente do clero "substituir às questões políticas, erroneamente predominantes nos governos, nos parlamentos e nos jornais, a questão social, que é a questão por excelência, porque ela afeta os interesses fundamentais do homem e da sociedade.

Ao sublinhar essa tradição de reivindicação que completava quarenta anos no início da década, os católicos entram nos anos 1930 com a consciência de que a organização operária é um dos polos principais de sua ação social naquele momento. Junto a ela, outra questão se mostrava tão ou mais importante: a educação.

No que se refere à educação, a principal luta era para que fosse afirmado o modelo de educação que conformasse o conhecimento com a moral, e para que se tornasse oferecido, como facultativo, o ensino religioso nas escolas públicas.

Os católicos defendiam uma educação que viam como integral, que não dissociasse ciência, arte e moral e que formasse o aluno nos ideais cristãos. A respeito da educação de cunho católico que seria a base pedagógica das nascentes Faculdades Católicas em 1941, o pe. Leonel Franca afirma: "aqui as disciplinas não se desenvolvem como membros desarticulados de um organismo. A formação do homem é integral" ${ }^{259}$. Lutava contra uma "desumanização do saber" e levava em conta que "o homem é uma unidade complexa. Sempre que essa complexidade o afasta de sua unidade substancial, tende a perder o contato com os pontos essenciais de sua personalidade" ${ }^{260}$. A instrução religiosa, segundo o ideário católico, seria o único meio de, ao aliar conhecimento e ciência às virtudes cristãs, 
reconciliar todas as coisas em Cristo. Esta concepção se opunha e enfrentava principalmente uma corrente pedagógica que ganhava força desde o século anterior, de concepção liberal e laicista, que era preconizada pelos educadores ligados ao movimento da Escola Nova.

Entre o golpe de 1930 e a Constituição de 1934, as discussões no campo da educação se intensificaram. Como resultado de uma aproximação inicial entre o governo provisório e a Igreja e os primeiros sucessos da campanha católica, em 1931, o Ministro da Educação e Saúde Francisco Campos assinou um decreto tornando facultativo o ensino religioso nas escolas públicas. Este decreto aguçou as disputas entre católicos e escolanovistas que seriam levadas à constituinte. Em 1932, mesmo ano de criação da LEC, é publicado o Manifesto dos Pioneiros da Educação Nova que reafirmava o conceito da escola laica, pública e universal. Nele, lê-se:

Toda a profunda renovação dos princípios que orientam a marcha dos povos precisa acompanhar-se de fundas transformações no regime educacional: as únicas revoluções fecundas são as que se fazem ou se consolidam pela educação, e é só pela educação que a doutrina democrática, utilizada como um princípio de desagregação moral e de indisciplina, poderá transformar-se numa fonte de esforço moral, de energia criadora, de solidariedade social e de espírito de cooperação. ${ }^{261}$

No mesmo ano de 1932, em texto na revista A Ordem, Alceu percebe que o

Manifesto tira a discussão do domínio da ambiguidade e começa a delimitar os campos de ação, com objetivos explícitos ${ }^{262}$. Ele vê no manifesto a expressão do laicismo pedagógico mais arraigado no sociologismo evolucionista e do materialismo biológico, que "revelam-se radicalmente anti-espiritualistas" 263. Sua crítica à Escola Nova é construída em última instância, explicitando-a como o projeto radicalmente oposto ao católico. Por isso é elucidativa a crítica que faz, por explicitar, como num espelho, seu próprio projeto:

Pois o manifesto é anti-cristão, porque nega a supremacia da fidelidade espiritual; é anti-nacional, pois, embora referindo-se ao 'cuidado com a unidade nacional', não leva em conta (...) nenhuma particularidade do temperamento e da tradição brasileira; e é também anti-liberal, pois se baseia no absolutismo pedagógico do Estado e na negação de toda liberdade de ensino. ${ }^{264}$

Na seção "Letras Católicas" do mesmo número de abril de 1932, Jonathas Serrano faz a resenha de um livro do ano anterior, de autoria de Tristão de Athayde, intitulado Debates Pedagógicos. No livro, a afirmação de Amoroso Lima sobre a abertura e os fundamentos da pedagogia cristã revelam o fato já tacitamente presente na crítica aos adversários. Ele afirma: 
O caminho da pedagogia católica a meu ver, deve ser justamente o estudo acurado de todos os métodos novos, introduzidos pela pedagogia moderna, de todos os fatos reveladores da psicologia experimental ou pelas experiências seculares do tema - à luz de uma filosofia verdadeiramente católica (p. XIX). ${ }^{265}$

Com a virada do século, acompanhada pelas mudanças que sofria o país, a educação ganhou ênfase na preocupação com a reestruturação da nação. Seria ela o grande motor da transformação, através do qual poder-se-ia resolver os problemas brasileiros. Nesse sentido, o Manifesto dos Pioneiros afirma:

$\mathrm{Na}$ hierarquia dos problemas nacionais, nenhum sobreleva em importância e gravidade ao da educação. Nem mesmo os de caráter econômico lhe podem disputar a primazia nos planos de reconstrução nacional. Pois, se a evolução orgânica do sistema cultural de um país depende de suas condições econômicas, é impossível desenvolver as forças econômicas ou de produção, sem o preparo intensivo das forças culturais e o desenvolvimento das aptidões à invenção e à iniciativa que são os fatores fundamentais do acréscimo de riqueza de uma sociedade. $^{266}$

As transformações que vieram com a República - tanto no plano econômico, político e social, como no âmbito cultural - criaram espaço para grandes correntes de ideias, atreladas a um momento de instabilidade e mudança que abriu caminho para pensar a educação como elemento basilar na construção de uma nação moderna. A partir da década de 1920, o ideal genérico de difusão da escolaridade para as classes populares vai ganhar formulações das mais diversas no que diz respeito ao modo como o ensino deve ser oferecido, e como este ensino é capaz de formar o homem para ser agente da transformação da nação. Sobre esse contexto, Jorge Nagle afirma:

Uma das maneiras mais diretas de situar a questão consiste em afirmar que o mais manifesto resultado das transformações sociais mencionadas foi o aparecimento de inusitado entusiasmo pela escolarização e de marcante otimismo pedagógico: de um lado, existe a crença de que, pela multiplicação das instituições escolares, da disseminação da educação escolar, será possível incorporar grandes camadas da população na senda do progresso nacional, e colocar o Brasil no caminho das grandes nações do mundo; de outro lado, existe a crença de que determinadas formulações doutrinárias sobre a escolarização indicam o caminho para a verdadeira formação do novo homem brasileiro. ${ }^{267}$

Os modelos de ensino são apropriados pelos grupos intelectuais, que, tendoos como suas bandeiras principais, defendem não apenas um projeto de educação, mas de ser humano e, em última instância, de nação. As disputas educacionais traduzem as disputas políticas ao passo que são traduzidas por estas. O movimento reacionário da Igreja Católica, que se opõe ao modernismo e ataca o liberalismo e o laicismo cultural, defendendo a moral cristã, encontra na escola o meio de divulgar sua concepção de mundo e formar os corações e mentes da 
futura nação por meio da recuperação de valores e ideias. Desde a Carta Pastoral de Dom Leme a Igreja da Restauração, ao atuar como agente social e ator político, alterou não somente os projetos da Igreja, mas fez alterar-se a própria identidade que confere coesão ao grupo católico. Nesse sentido, Alcibíades Delamare afirmava à época que:

Para atingirmos à Brasilidade, isto é para termos a Pátria reivindicada, restabelecida, entregue a si própria, só o conseguiremos pelo Catolicismo, que é a alma do Brasil. Que valem os projetos de difusão da instrução pública, de guerra contra o analfabetismo, se a instrução nada é sem a educação e a educação nada é sem a religião? ${ }^{268}$

É importante levar em conta a questão da identidade como um dos argumentos base que corrobora o significado questão da educação e do otimismo pedagógico, segundo Nagle, como pontos fundamentais da luta pelo futuro da nação. É por este motivo que a escola ganha tamanha importância para a Ação Católica. A educação católica não era um projeto incipiente que se buscava pôr em prática. Era vista como uma realidade nas inúmeras escolas fundadas pelas congregações religiosas que nos primeiros anos da República aqui se instalaram. Mais de cem congregações masculinas entraram no Brasil nos primeiros anos republicanos e boa parte fundou instituições de ensino. Na década de 1920, porém, as conquistas da Igreja frente o Estado no campo da educação são muito pouco expressivas. A década de 1920, com a orientação do laicato empreendida por Jackson de Figueiredo, dera aos grupos intelectuais católicos forte combatividade política, mas de poucos resultados efetivos no meio cultural ou educacional. A atuação na cultura e na sociedade ocorre de forma dispersa e sem expressividade, e a derrota das emendas católicas na reforma constitucional do governo de Artur Bernardes é expressão do escasso alcance do movimento de então. Tânia Salem afirma sobre esse período que "no que tange à educação, pode-se concluir que, se por um lado, é fato que esse momento assinala a aparição do grupo católico na arena pedagógica, de outro - em termos de avanços concretos -, os resultados atingidos são pouco significativos" ${ }^{269}$.

A partir da virada da década de 1930, em paralelo com as mudanças político-sociais, a reforma proposta por Alceu Amoroso Lima não apenas na revista A Ordem, mas na orientação do movimento católico como um todo, trará novos ares a tais disputas. Mais preocupado com assuntos culturais, o esforço empreendido nesta área se materializará em algumas instituições que surgem neste momento. São criados centros de educação, tanto superiores, como a Associação 
Universitária Católica (AUC), em 1929, e o Instituto Católico de Estudos Superiores (ICES), em 1932, e as Faculdades Católicas em 1940 quanto em relação ao ensino básico e às questões pedagógicas, como a Associação de Professores Católicos, em 1931, e, em 1933, a Confederação Católica Brasileira de Educação. Sobre isso, Tânia Salem ressalta:

A ênfase mais cultural imprimida ao movimento a partir de 1928, a criação de organizações leigas especificamente voltadas para um trabalho no setor de ensino e o maior poder de barganha da Igreja vis-à-vis ao Estado - são elementos que propiciam as vitórias alcançadas pelo grupo no campo educacional nos anos seguintes. Nesse sentido, esses fatores evidenciam também o afunilamento da trajetória que os católicos percorrem até desembocar na criação de um centro próprio de ensino superior. ${ }^{270}$

Em 1934, Gustavo Capanema assume como novo Ministro da Educação e Saúde Pública, e Peri Mesquida ressalta: “Alceu iria aproveitar a presença de seu amigo Capanema no Ministério da Educação e Saúde para desenvolver uma intensa 'guerra de posição', situando intelectuais leigos e clérigos da Igreja em postos-chave naquele Ministério" ${ }^{271}$. No mesmo ano, Carlos Drummond de Andrade, também amigo de Alceu, foi nomeado chefe de gabinete do mesmo ministério. Leandro Garcia Rodrigues ressalta a importância da relação dos dois na influência que Alceu tinha dentro do ministério, e como a partir desta aproximação pode ajudar amigos e alavancar projetos e intelectuais católicos em diversas ocasiões ${ }^{272}$. Garcia Rodrigues ainda atenta para o "complexo e intenso mecenato exercido por alguns artistas e intelectuais" como elemento de grande importância para "a compreensão da vida literária modernista como um todo" ${ }^{273}$, tendo sido o próprio Alceu que indicou Drummond para o cargo assumido. A nomeação de Capanema abre as portas do Ministério para uma ação mais profunda nas decisões educacionais. Peri Mesquida afirma que:

Se a grande batalha moderna está sendo "travada" no campo "das ideias", a presença da intelectualidade leiga católica em posições chave do Ministério da Educação é imprescindível. Por isso, Alceu não poupou esforços no sentido de "colocar" pessoas de "confiança" e que tenham comprovado serem fiéis "à nossa causa", em particular aquelas que tenham passado pelos Centros Dom Vital, em postos nos quais e por meio dos quais elas poderiam atuar em favor da Igreja Católica. ${ }^{274}$

A partir das vitórias das reivindicações católicas na constituinte de 1934, a presença do grupo católico nas questões educacionais ganha outro peso. A luta se voltaria, a partir de então, principalmente para a esfera do ensino superior. A AUC agregava a juventude universitária, promovia ações e debates, enquanto o ICES, criado já como primeiro germe da futura Universidade Católica que seria fundada 
em 1940, ministrava cursos de nível superior, visando ser uma "pedra pequenina e humilde" na "grande restauração do sentido da integralidade científica, que hoje domina os círculos mais elevados do pensamento católico" ${ }^{275}$. O projeto pedagógico católico expressa, no âmbito da educação, os valores mais básicos que pautam suas outras ações. A educação buscava a formação de um homem culturalmente superior, o intelectual que estaria à frente do povo, conduzindo a nação de volta a um rumo cristão. Se a educação básica era responsável por plantar no indivíduo o germe da moral católica, o ensino superior seria responsável por formar o intelectual e as lideranças para o país.

A complementaridade entre os projetos operários e educacionais que a Ação Católica põe em pauta pode ser entendida dentro do próprio pensamento católico de busca de uma síntese. Atuando nas bases mais baixas e nas esferas mais elevadas, a Igreja criava duas frentes de ação - e de disputa que mutuamente se harmonizariam. Aos intelectuais condutores da sociedade a serem formados pelo ensino superior integral, era necessária uma população que recebesse com mente e corações abertos seu discurso e sua ação. A estruturação da sociedade a partir de uma classe trabalhadora organizada - algo que parecia inadiável para os grupos intelectuais daquele momento - alicerçada em fundamentos católicos, que viabilizaria a condução eminentemente católica do país. A todo momento, quando Alceu se ocupa da ação, seja diretamente, seja ao aludir a aspectos da atuação católica como educação, questão social - além de outras menos recorrentes mas também importantes como a questão das forças armadas, do divórcio, do sufrágio de religiosos - a afirmação da nacionalidade está presente. Raras são as vezes que, ao invocar a dimensão ativa da catolicidade, a presença da nacionalidade como régua universal dos atos humanos não apareça. Educação e trabalho, operários e intelectuais. Sob a sombra da Cruz todos poderiam harmonizar-se, se em contato com as próprias bases do que os une, sua nacionalidade histórica e latente.

\subsection{O Itinerário em trajetos}

O sucesso que os católicos obtiveram com as suas reivindicações na Constituição de 1934 não passou despercebido. O longo caminho do laicato para fundamentar uma campanha cultural que incentivasse a aproximação do Estado com a Igreja dava seus primeiros frutos numa constituição marcada pelo sucesso visível da Liga Eleitoral Católica e suas reivindicações. A Ordem não deixa de comemorar esse notável fato, e chama a atenção para os frutos da ação cultural 
sem deixar de inserir a vitória na narrativa, vista como histórica, da religiosidade no Brasil. A Constituição teria marcado o primeiro passo da retomada da Igreja no caminho da recristianização do mundo moderno no Brasil, sendo vista como a maior vitória da catolicidade desde que o Brasil se tornou independente. Em três textos, publicados nos números consecutivos de maio, junho e julho, Alceu comunica, comemora, analisa e pondera os sentidos desta vitória. Fora aprovada a institucionalização da relação de cooperação entre o Estado e a Igreja, considerada como religião do povo, e o ensino católico facultativo nas escolas públicas.

As duas vitórias mais alardeadas pela revista sugerem a possibilidade de continuação da luta nos dois polos de ação desenvolvidos anteriormente. A cooperação com o Estado permite uma maior presença da Igreja junto à classe trabalhadora, seja enquanto representante dos trabalhadores frente ao governo, seja enquanto representante do governo frente aos sindicatos. Já as vitórias no que diz respeito à educação ampliaram a possibilidade de ação sobre os jovens. A luta no campo legal acerca da educação passaria a focar-se no ensino superior. Os frutos dessa "longa campanha de ideias" que há mais de uma década havia se iniciado mostravam a força católica no campo das ideias baseada numa "ação política, extra-partidária mas incessante e generalizada, em todo o Brasil, em defesa de nossas posições" ${ }^{276}$ que, afirmava o artigo, há quatro anos, quando a continuidade da República pela primeira vez se quebrou, começaram a trabalhar os católicos "com absoluta confiança no futuro" 277 .

Nesse período de debates, em que a ação - em suas dimensões política, social e cultural - ganhou centralidade, a mobilização de Alceu Amoroso Lima tomou proporções, frente ao laicato, de posição oficial da Igreja ${ }^{278}$. Sua intensa publicação em livros e artigos, revistas e jornais, sua posição como diretor do Centro Dom Vital e da Liga Eleitoral católica mobilizando politicamente os católicos e catolicamente os políticos, são fundamentais para a conquista de uma posição preeminente para a Igreja, para os leigos organizados e para o próprio Alceu. A Ordem, a partir de janeiro de 1931, quando "todos veem a multiplicidade de caminhos que se abrem a nossa frente à espera de nossa escolha" e que "o Brasil se acha em plena disponibilidade" ${ }^{279}$, passa a publicar, como abertura de cada edição, um texto editorial não assinado que serviria como um discurso programático centralizador a todos os católicos. Tendo em vista a posição de Amoroso Lima no laicato católico, seu lugar de arregimentador cristão, 
além de coincidências visíveis nas temáticas dos editoriais e de suas publicações, é possível presumir que tais editoriais também dentro da narrativa amorosiana. Além disso, em um escorregão num editorial de 1932 começa a escrever em primeira pessoa na condição de diretor do Centro.

Depois de "Posição", primeiro texto editorial, lançado em janeiro de 1931, os três seguintes se dedicam à análise da decadência da burguesia enquanto organizadora da sociedade. "O Suicídio da Burguesia", "A Agonia da Burguesia" e "A Salvação da Burguesia" traçam a imagem de uma burguesia que, afastandose progressivamente da moral cristã ou deturpando-a, levou ao descalabro da sociedade burguesa ${ }^{280}$, que agoniza face às inúmeras ideologias revolucionárias ${ }^{281}$. Sua única salvação, para Alceu, seria o abandono de suas veleidades revolucionárias e o esforço em abraçar a fé católica e a Verdade ${ }^{282}$. Neste mesmo período, Amoroso Lima preparava uma série de conferências sobre este tema, que seriam publicadas em seguida com o nome Problema da Burguesia. Nelas, ele percebe, assim como nos editoriais, que sua geração nascera na transição que entre

o otimismo do século XIX, que já começava a desmentir-se e o pessimismo do século XX, que ainda apenas apontava, nascíamos nós em um crepúsculo de ceticismo, em uma era de mediocridade, social e mental, em que o mundo nos parecia irremediavelmente desinteressante e inútil. ${ }^{283}$

Os três editoriais que se seguem traçam as três questões centrais a serem enfrentadas para o Alceu daquela época, para os católicos de então e para a hierarquia da Igreja: a "Educação Religiosa" (maio 1931), o "Monismo Sindicalista" (junho 1931) e a relação "Estado e Igreja” (julho 1931). Primeiro os textos buscavam identificar o problema, ao fazer uma análise do presente. Em seguida, pautavam as diretrizes da ação.

No primeiro dos três editoriais, o autor comenta o decreto que "facultou de novo o ensino religioso nas escolas públicas nacionais" ${ }^{284}$, e comemora como uma grande vitória da nacionalidade, que de outro modo, através do ensino laico, não poderia formar-se. O momento, afirma, era de luta, as objeções aparecem como obstáculos de uma nacionalidade que deve voltar e se reconciliar com suas origens.

No texto seguinte critica a lei de sindicalização por negar todo caráter religioso da questão $\operatorname{social}^{285}$, além de reconhecer apenas um modo de organização sindical. Isso, no seu entender, vai contra o papel histórico da Igreja. 
O decreto coincide com a comemoração de quarenta anos da encíclica Rerum Novarum de Leão XIII e de lançamento da encíclica Quadragesimmo Anno, escrita em sua homenagem e atualização.

Sua lição é a que a Igreja pretende dar ao século: "Mantendo sempre ilesos os seus princípios e entretanto desvendando novos horizontes a todos os seus adversários ou indiferentes que querem ser modernos escravizando-se às circunstâncias e repudiando os princípios como um peso inútil do passado" 286 . Por isso mesmo propõe coerência ao governo provisório decidindo se alinha-se ao movimento de recristianização ou não - uma vez que oficializa um Ministério da Educação que reconhece a religião mas também um Ministério do Trabalho que a nega ${ }^{287}$. A complementaridade necessária das duas questões tornaria tal atitude um paradoxo inaceitável.

No terceiro dos textos a relação entre Igreja e Estado é posta no contexto maior da relação entre o poder político e o poder religioso. Essa dualidade fundamental da natureza humana em sociedade requer, para o autor, um aprofundamento em suas bases. Após traçar esta leitura histórica, é exaltada a Idade Média como um momento harmonioso de equilíbrio entre os dois. Segundo o texto, o "pensamento político medieval repugnava todo tipo de monismo político" ${ }^{288}$. Sugere que o pensamento corrente sobre o período medieval deveria ser reabilitado para que se compreendesse o suposto papel da multiplicidade de formas com que esse se organizou. A Idade Média, que para o autor seria sempre lida erroneamente em bloco como uma totalidade de mil anos, seria, em sua visão, lugar de referência para o tipo de cooperação entre poder político e poder religioso que se pretende propor.

Dadas as bases de interpretação e ação, o caminho estava traçado para a revista empreender seu projeto de recristianização do mundo moderno, sobre bases que se aliassem a princípios eternos. Sempre a partir dessas chaves, jogando com as noções de materialismo e espiritualismo, que a revista lê o mundo e pretende atuar sobre ele.

A partir de 1932, principalmente quando as forças políticas já se organizam em torno da proposição de uma constituinte, a voz da revista se tornará cada vez mais enfática acerca dos temas contemporâneos. Já em dezembro de 1931 são transcritos textos e discursos do Cardeal Leme reivindicando leis protetoras do 
trabalho $^{289}$. Atacando as movimentações de grupos pró-estado laico, propõe uma ação que aja sobre o Estado para conservar a Nação ${ }^{290}$.

É marcante por toda a revista a dimensão da ação - que no entender de seus membros visa não a mudança, mas a conservação. Por isso, sugere a não intervenção em crises como a revolta constitucionalista de São Paulo, mas ao contrário indica que os católicos moldem sua ação às exigências do contexto, compreendendo as causas dos conflitos para poder agir sobre eles, para que se atinja o Estado como um todo. Não tomar partido, nesse caso, seria a forma mais eficiente de atingir todos os partidos.

Nos vários números da revista os textos multiplicam as propostas, sublinham as brechas de engajamento. Os textos dão forma ao corpo de editoriais da revista, e se constituem na expressão e na ampliação da voz do próprio Tristão, considerado como uma figura centrípeta. Todos os editoriais se desenvolvem no campo argumentativo definido ao longo desse trabalho. Todos recorrem à nacionalidade, fundada nessa identidade brasileira originária, para fundamentar seus pontos de vista, inserindo o momento atual em um processo histórico de desespiritualização do mundo e do Brasil. Todos entendem a relação entre Igreja e Povo, na duplicidade sugerida por Júlio Maria, como uma relação que tem seus polos principais na educação e no mundo do trabalho.

A revista A Ordem se reveste do papel de grande bastião da discussão acerca da nacionalidade brasileira. Evidente que o discurso "oficial" de Amoroso Lima não é o único. Nomes como Plínio Correa de Oliveira, Luis Delgado e Sobral Pinto trazem outras possibilidades de interpretação que se não opostas, são pelo menos diversas. Se pode haver complementaridade ou não entre essas interpretações, deixo este trabalho para um possível futuro. Ainda assim, a dimensão da ação dos católicos como força no mundo moderno está presente também em outros textos como casos de de Jonathas Serrano e de Mello e Souza, ou Everardo Backheuser. A variedade de vozes na Ordem é visível, e a interpretação amorosiana não pode ser vista como única e totalizante. Contudo, creio que a compreensão de como Alceu ordena o mundo à sua volta e a nação ao seu passado pode ser vista sob a forma de um itineráio. Como um itinerário de viagem, ele sugere um caminho, um desencadeamento. Bem sabemos que os caminhos do mundo são vários e vários são também seus descaminhos. Dependendo de quem o segue, essa sugestão pode sofrer alterações, mudanças, 
retomadas. O itinerário amorosiano proposto ao laicato católico, com a benção do Cardeal Leme e do Padre Leonel Franca, cumpre esse papel. Ele propõe um caminho, uma base, a ser alterada ou modificada por quem o segue. Essa alteração, contudo, só pode ser feita a partir do momento que o itinerário é bem compreendido.

Este itinerário - que Alceu organiza a partir do pensamento católico extrapola a própria revista ou o campo dos discursos políticos. Em texto que publiquei recentemente, analisei as formas como a construção das imagens de Cristo construídas pela cidade - em especial duas, o Cristo Redentor e Cruzeiro da Universidade - carregam o discurso da Igreja tanto pelo que se fala dela como pela sua própria composição estética. Na construção do Cristo Redentor, no alto do Corcovado, em 1931, e do Cruzeiro, ao lado do Santuário da Penha, em 1941, a nacionalidade enquanto passado perdido cumpriam papel apologético imprescindível, como afirmei então:

As duas imagens que dão corpo a esse trabalho representam esta memória, que se materializa na forma de imagens de Cristo. O Cruzeiro da Universidade, assim como o Cristo Redentor, representa tanto o passado como o futuro. É expressão de um tempo ideal, de uma "devoção tradicional". Expressa a busca por uma cristandade perdida, um grande ideal de restauração daquilo que um dia foi uma nação eminentemente católica, a Terra de Santa Cruz, como dizem os jornais na inauguração do Cristo. Ao mesmo tempo, olha para o futuro numa perpetuação, pela eternidade, dos grandes feitos da Igreja, da dimensão de fé e patriotismo que ali está posta. É um símbolo que, ao passo que sintetiza um passado, carrega em direção a um futuro sem fim aquilo que seus criadores defendem. O Cruzeiro olha para o passado, simboliza-o e carrega o presente em direção ao futuro. Ele está no limiar, na quebra do tempo presente que busca o passado e se dirige à eternidade. A memória, como manifestação do passado no presente, ganha corpo no corpo de Cristo, e se projeta para a eternidade. A primeira inscrição no Cruzeiro nos faz refletir: AD PERPETUAM REI MEMORIAM [Para rememoração perpétua]. Para preservar através dos tempos o grande feito que teria sido a fundação das Faculdades Católicas, este memorial se volta tanto para o passado como para o futuro, enquanto simboliza um passado ideal e transpassa o tempo como profecia do tempo presente. Na Ata de Ereção do Cruzeiro, fala-se do objetivo do monumento, em vista a "propagar através dos séculos a devoção tradicional da cidade". ${ }^{291}$

O itinerário amorosiano ordena e organiza, em sentido ativo, as formas dialógicas entre o mundo e o eu. O cristão projeta no mundo a sua fé e é moldado por ela. Sua voz reverbera e ecoa nos mil tons da modernidade que se reorganiza com o suposto fim do mundo burguês. O passado é exaltado como força viva que ordena o presente. $\mathrm{O}$ futuro se estende ao passado não como imitação, mas como revitalização. As forças eternas e atemporais devem moldar um mundo novo não na chave da ruptura, mas na chave da superação. 


\section{Conclusão}

Tramas, tecidos, traços, terremotos, veredas, vales, correntezas. Muitas foram as imagens utilizadas na tentativa de auxiliar a composição de um quadro geral que ordenasse a interpretação que aqui busquei apresentar. E muitas mais poderiam contribuir para que o sentido sempre incompleto da ação dos homens no tempo - como Marc Bloch define o objeto de estudo da História - possa ser compreendido nas suas variadas perspectivas.

A partir da vida de Alceu Amoroso Lima, bem como da memória construída e consolidada sobre a vida desse intelectual pude buscar traçar sua trajetória em diálogo com os caminhos da década. Pude perceber, nos anos em que as formas consolidadas de poder - político, cultural, social - mostravam-se saturadas e que na sociedade brasileira os agentes e os discursos se reorganizavam, como a trajetória de um homem conduz seus passos físicos e simbólicos na relação com o mundo a sua volta. Foi essencial, para que pudesse conferir mais precisamente o peso que carregavam seus textos, entender a trajetória de Amoroso Lima, não como um intelectual inserido em um contexto, mas como agente, ou melhor, reagente, em sentido químico, no tecido simbólico da existência, e como suas palavras tomavam a forma de forças produtoras de sentido nesse mundo.

Foram duas as inquietações que suscitaram o meu interesse e consequente engajamento na pesquisa aqui desenvolvida. Inquietações que brotaram de uma frase e de uma estátua.

Refiro-me à frase já citada em que Alceu, em entrevista de 1928, afirma que "se não fosse católico, seria comunista" ${ }^{292}$. Robert Darnton, ao escrever $O$ Grande Massacre de Gatos, evoca a antropologia ao afirmar que o grande ponto de penetração em uma cultura distinta deve ser por meio de um estranhamento, a partir do qual se pode descobrir uma entrada para um sistema estranho de

significação $^{293}$. A frase de Amoroso Lima, para um estudante que apenas começava uma pesquisa sobre a história do pensamento católico, soava estranha e fora de lugar. A partir dela, o interesse pela interpretação que Alceu criava do mundo a sua volta e dentro de si tomou fôlego. A frase, obviamente mais retórica do que sincera, explicita, como pude perceber, a dimensão de engajamento total que ele via necessário ao sujeito de sua época. Pude ainda perceber ao longo da pesquisa como sua interpretação do mundo se entrelaçava com o contexto político 
e simbólico, de forma a poder extrair os significados a partir do estabelecimento dessa relação.

Em segundo lugar, a estátua: a construção do Cristo Redentor, evidencia que tal inquietação ganhava ainda outra face. Tal como foi construído, o monumento a Cristo no alto do morro do Corcovado me parecia ser a materialização dos discursos católicos, no sentido mais etimológico do termo. Voltado sempre para o futuro, ao representar um projeto de recristianização do país, o monumento fazia evocar um passado ideal de formação cristã que deveria ser retomado. Esse aspecto discursivo do monumento me chamou atenção especialmente pela relação, à época ainda nebulosa, da relação entre o campo simbólico, discursivo, e a materialidade intrínseca à intervenção urbana que representava a construção de uma estátua religiosa de mais de trinta metros no coração da capital do país. Foi a partir da perspectiva de formação da cidade letrada, de que fala Angel Rama, que pude compreender o modo particular como essas dimensões estavam profundamente imbricadas.

A compreensão da luta pelo domínio da cidade letrada no cerne das disputas que marcaram as décadas de 1920 e 1930, portanto, me permitiram interpretar o pensamento de Alceu como proposta, como ação e, em última instância, como itinerário. Nessa perspectiva pude ler as fontes de maneira mais aprofundada e consciente, e clareavam-se as intenções e tensões que as palavras de Alceu carregavam. A construção histórica, assunto tão caro aos católicos - e aos conservadores em geral -, se mostraria como argumento central na formação de todo pensamento amorosiano e, consequentemente, de toda ação a ser empreendida no mundo pelos católicos. Essa construção se fundamentava em em duas faces: Em primeiro lugar, entendia a Igreja e a religiosidade dentro de uma história processual, que tem coerência e movimentos internos para, em segundo lugar destacar, através do atributo da santidade, o que subsistiria de eterno nesse processo, a exemplaridade dos homens santos que é vista como atemporal e deveria ser imitada no presente.

No processo histórico assim entendido, a modernidade é tida como perda, como afastamento de um ideal que estaria no passado. Do ponto de vista do pensamento católico de ultramar, vindo da Europa, esse momento seria a Idade Média, um período, segundo tais pensadores, em que a religiosidade reinara em plena liberdade e que teria sido destruído ao longo da formação da modernidade 
até a década de 1920. Exaltada pelos intelectuais em torno da revista $A$ Ordem, a Idade Média ganha uma espécie de apêndice no Novo Mundo: o período colonial é explicitamente compreendido como um prolongamento da Idade Média nas Américas, um período no qual o povo teria sido formado com índole e características exclusivamente católicas.

Seja a Idade Média ou o período colonial, o mito desse tempo perdido, idade de ouro da religiosidade esquecida na degeneração do mundo moderno, é construído como cerne articulador de toda interpretação de mundo. Essa tradição inventada - não necessariamente no sentido de Hobsbawm - constitui o mito fundador do pensamento conservador católico. Essa tradição, segundo seus defensores, se encontraria latente no povo, que nunca abandonou suas origens cristãs, mas que foi tirado do caminho por elites desviantes. Moralizar o mundo, portanto, seria trazer o povo à sua verdadeira origem que os católicos afirmavam ter encontrado nesse passado mítico e portanto, inventado. O papel das elites deveria ser então o de fazer retornar o povo ao seu verdadeiro eu, que no Brasil ganhou os contornos da nacionalidade que havia se tornado central nas discussões da década de 1930.

As perspectivas de ação no mundo a ser empreendida pelos católicos estavam diretamente vinculadas a essa construção histórica. A partir de duas frentes - a questão social e a educação - essa ação deveria conduzir o povo de novo ao rumo que havia perdido. Condicionada ao passado, a ação se encaminhava ao futuro como retomada no interior de uma historicidade marcada pela perda e pela ausência no mundo moderno. O caráter divinatório e teleológico desse processo histórico surgia como uma forma de, a partir do contexto e das ferramentas modernas, superar os problemas do mundo pelas chaves da superação e da recuperação.

A compreensão do modo como o pensamento conservador de Amoroso Lima se constrói nesses anos, e o caráter de atualização com que ele se reveste, abrindo espaço para novas linguagens e novas ciências - como a estatística e a etnografia - apenas na medida em que permitem traçar esse caminho de retomada, torna-se mais valioso quanto mais nos vemos envoltos nos incertos ares dos dias atuais.

Cada vez mais, a compreensão de tais construções se faz necessária, na medida em que nos vemos, analogamente aos incertos anos 1920, cada vez mais 
acometidos pelas vias radicais com que as mudanças políticas e sociais se mostram de forma simultaneamente nebulosa e enfática. Iniciada em um contexto radicalmente diferente - apesar da proximidade temporal - essa pesquisa ganhou novos significados ao longo de seu desenvolvimento. Torna-se inescapável para mim compreendê-la também como uma possível contribuição para os dias atuais.

Correntezas, tecidos, luzes, fogos. A única metáfora que não posso aceitar é a da inércia. 


\section{Bibliografia}

A ORDEM - Vol. VIII, n. 1, dez. 1928 a Vol. XII, n. 58 dez.1934

ARAÚJO, Ricardo Benzaquen de. Totalitarismo e Revolução - o integralismo de Plínio Salgado. Rio de Janeiro: Jorge Zahar Editor, 1988.

ARDUINI, Guilherme Ramalho. O Centro Dom Vital: estudo de caso de um grupo de intelectuais católicos no Rio de Janeiro entre os anos 1920 e 1940. In: RODRIGUES, Cândido M.; PAULA, C. J. (Org). Intelectuais e Militância Católica no Brasil. Cuiabá: EdUFMT, 2012.

ARDUINI, Guilherme Ramalho. Em Busca da Idade Nova: Alceu Amoroso Lima e os Projetos Católicos de Organização social (1928-1945). São Paulo: Editora da Universidade de São Paulo, 2015.

ARDUINI, Guilherme Ramalho. Os soldados de Roma contra Moscou: a atuação do Centro Dom Vital no cenário político e cultural brasileiro (Rio de Janeiro, 1922-1948). 2014. Tese (Doutorado em Sociologia) - Faculdade de Filosofia, Letras e Ciências Humanas, Universidade de São Paulo, São Paulo, 2014.

ATHAYDE, Tristão de. Política. Rio de Janeiro: Editor Getulio Costa, 1939. $3^{\text {a }}$ ed.

LIMA, Alceu Amoroso. Contra a Revolução Espiritual. Cataguazes: Spinola \& Fusco editores, 1932.

ATHAYDE, Tristão de. Preparação à Sociologia. Rio de Janeiro: Schmidt editor, 1931.

ATHAYDE, Tristão de. Problema da Burguesia. Rio de Janeiro: Schmidt editor, 1932.

AUSTIN, John Langshaw. Quando dizer é fazer. Porto Alegre: Artes Médicas, 1990.

AZZI, R. A Neocristandade: Um Projeto Restaurador. São Paulo: Paulus, 1994 - (História do pensamento católico no Brasil; v. 5)

AZZI, R. O Início da Restauração Católica no Brasil (1928-1930). Síntese, vol. 4, n. 10, p. 61-90, 1977.

AZZI, R. O Início da Restauração Católica no Brasil (1928-1930) II. Síntese, vol. 4, n. 11, p. 74-101, 1977. 
AZZI, Riolando. O Fortalecimento da Restauração Católica no Brasil (1930 1940). Síntese, vol. 6, n 17, p. 69-85, 1979.

BARBOSA, Francisco de Assis (org.). Intelectuais na Encruzilhada: Correspondência de Alceu Amoroso Lima e António de Alcântara Machado (1927 - 1933). Rio de Janeiro: Academia Brasileira de Letras, 2002.

BOURDIEU, Pierre. A economia das trocas simbólicas. São Paulo: Perspectiva, 1974.

BOURDIEU, Pierre. Esboço de uma auto-análise. São Paulo: Companhia das Letras, 2005.

CANDIDO, Antonio; CASTEllO, José Aderaldo. Presença da Literatura Brasileira (História e Antologia) - Volume III: Modernismo. São Paulo: Difusão Européia do Livro, 1964. 381p.

CASALI, Alípio. Elite Intelectual e Restauração da Igreja. Petrópolis: Vozes, 1995.

COSTA, Marcelo da Silva Timotheo da. Um itinerário no século: mudança, disciplina e ação em Alceu Amoroso Lima. Rio de Janeiro: Ed. PUC-Rio; São Paulo: Loyola, 2006.

CPDOC -FGV. Dicionário Histórico-Biográfico Brasileiro - DHBB. Fundação Getúlio Vargas. Disponível em: <http://www.fgv.br/cpdoc/acervo/arquivo>. Acesso em: 16 mar 2016.

DECCA, Edgar Salvadori de. O silêncio dos vencidos. São Paulo: Brasiliense, 1981.

ENDERS, Armelle. A História do Rio de Janeiro. Rio de Janeiro: Gryphus, 2008.

ETIENNE FILHO, João (org.). Correspondência: Harmonia dos Contrastes (1919 - 1928)- Tomo 1. Rio de Janeiro: Academia Brasileira de Letras, 1991.

FACULDADES CATÓliCAS. Anuário das Faculdades Católicas, 1941. Rio de Janeiro, 1942.

FARGE, Arlette. O Sabor do Arquivo. São Paulo: Edusp, 2009. 120p.

FAUSTO, Boris. “A Revolução de 1930”. In: MOTA,Carlos Guilherme. Brasil em Perspectiva. São Paulo: Bertrana Brasil, 1987 (16º edição).

FAUSTO, Boris. "Revolução de 1930 e classes médias". In: A Revolução de 1930. Historiografia e história. São Paulo: Companhia das Letras, 1997, $2^{\circ}$ edição. 
FAUSTO, Boris. História do Brasil. São Paulo: Editora da Universidade de São Paulo, 2015. (Didática, 1).

FERREIRA, Jorge; DELGADO, Lucilia de A. N (org). O Brasil republicano - O tempo do Liberalismo Excludente: da Proclamação da República à Revolução de 1930 Vol. 1. Rio de Janeiro: Civilização Brasileira, 2003.

FERREIRA, Jorge; DELGADO, Lucilia de A. N (org). O Brasil republicano - O Tempo do Nacional Estatismo:do início da década de 1930 ao apogeu do Estado Novo. Vol. 2. Rio de Janeiro: Civilização Brasileira, 2003.

FIGUEIREDO, Aldrige Moura de. Leituras Insulares: leituras e formas da história no modernismo brasileiro. In: CHALHOUB, Sidney; PEREIRA, Leonardo Affonso de M. (Orgs.). História Contada: capítulos de história social da literatura do Brasil. Rio de Janeiro: Nova Fronteira, 1998.

FOUCAULT, Michel. A Verdade e as Formas Jurídicas. Rio de Janeiro: NAU, 2013.

FOUCAULT, Michel. A Ordem do Discurso. São Paulo: Edições Loyola, 2014.

GEERTZ, Clifford. A Interpretação das Culturas. Rio de Janeiro: LTC, 2008. $323 \mathrm{pp}$.

GINZBURG, Carlo. Sinais: raízes de um paradigma indiciário.In: Mitos, emblemas, sinais: Morfologia e História. São Paulo: Companhia das letras, 1987. p. 143-179.

GOMES, Ângela de Castro. História e historiografia de A Revolução de 1930. In: Leituras críticas sobre Boris Fausto. São Paulo: Perseu Abramo, 2008.

GOMES, Ângela de Castro. Essa Gente do Rio: Modernismo e nacionalismo. Rio de Janeiro: Editora Fundação Getúlio Vargas, 1999. 115p.

GOMES, Francisco José Silva. De súdito a cidadão: os católicos no Império e na República. Anais do XIX Simpósio Nacional de História. Belo Horizonte: ANPUH, 1997.

GOUVEIA, Saulo. The Catholic crusader and the folklorist: Alceu Amoroso Lima and Mário de Andrade as founding fathers of modernist criticism and historiography. Chasqui: Revista de literatura latino-americana, vol. 41, n. 1, p. 37-58, 2012.

GRAMSCI, Antonio. Os Intelectuais e a Organização da Cultura. Rio de Janeiro: Civilização Brasileira,1968. 
HELENA, Lúcia. Modernismo Brasileiro e Vanguarda. São Paulo: Editora Ática, 2005. $3^{\mathrm{a}} \mathrm{Ed}$.

HOBSBAWN, Eric; RANGER, Terence. A invenção das tradições. Rio de Janeiro: Paz e Terra, 1984.

JASMIN, Marcelo Gantus. História dos Conceitos e Teoria Política e Social: referências preeliminares. Revista Brasileira de Ciências Sociais, V.20, n. 57, fev. 2005.

JASMIN, Marcelo Gantus; JUNIOR, João Feres (Orgs.). História dos Conceitos: Debates e Perspectivas. Rio de Janeiro: Ed. PUC-Rio/Edições Loyola/IUPERJ, 2008.

JUNIOR, Guilherme Simões. Crítica, combate e deriva do campo literário em Alceu Amoroso Lima. Tempo Social, v.23, n.2, p.101-133.

KAZ, Leonel; LODDI, Niggle (orgs). Cristo Redentor: História e Arte de um Símbolo do Brasil. Rio de Janeiro: Aprazível Edições, 2007/2008.

LEÃO XII. Carta encíclica "Rerum Novarum" do sumo pontífice Papa Leão XII. Disponível em $<$ http://w2.vatican.va/content/leoxiii/pt/encyclicals/documents/hf_1-xiii_enc_15051891_rerumnovarum.html> . Acesso em 26 abr. 2017.

LIMA, Alceu Amoroso. Adeus à disponibilidade e outros adeuses. Rio de Janeiro: Agir, 1969.

LIMA, Alceu Amoroso. Contra a Revolução Espiritual. Cataguazes: Spinola \& Fusco editores, 1932.

LIMA, Alceu Amoroso. Introdução à Economia Moderna. Rio de Janeiro: Livraria AGIR editora, 1956. $2^{\mathrm{a}} \mathrm{ed}$.

LIMA, Cláudio de Medeiros. Alceu Amoroso Lima, Memórias Improvisadas Diálogos com Medeiros Lima. Petrópolis: Vozes, 1973. 334pp.

ATHAYDE, Tristão de. Política. Rio de Janeiro: Editor Getulio Costa, 1939. $3^{\text {a }}$ ed.

MACCIOCCHI, Maria-Antonieta. A Favor de Gramsci. Rio de Janeiro: Paz e Terra, 1977.

MARIA, Júlio. A Igreja e a República. Brasília: Editora Universidade de Brasilia, c. 1921.

MESQUIDA, Peri. Educação na Restauração Lemista da Igreja: a missão de Tristão de Athayde e Stella de Faro no Ministério da Educação e Saúde 
Pública. Revista Diálogo Educacional, v. 9, n. 27, p. 279-295, maio/ago. 2009.

MESQUIDA, Peri. O Processo Político de Restauração da Igreja: educação e os intelectuais orgânicos (1916 - 1940). Revista HISTEDBR On-line, n.31, p.31-40, set. 2008 .

MICELI, Sergio. Intelectuais à brasileira. São Paulo: Companhia das Letras, 2001.

MONTALBAN, Francisco J. Historia de La Iglesia Católica: IV Edad Moderna - La Iglesiaensu Lucha y Relaciónconel Laicismo. Madrid: Biblioteca de Autores Cristianos, 1963.

MORAES, Eduardo Jardim de. A brasilidade modernista - sua dimensão filosófica. Rio de Janeiro: Ed. PUC-Rio, Ponteiro, 2016. Edição revisada e atual. $142 \mathrm{p}$.

MORAES, Eduardo Jardim de. Modernismo Revisado. Estudos Históricos, v.1, n.2, 1988.

MORAES, Eduardo Jardim de. Mário de Andrade: Eu sou trezentos: vida e obra. Rio de Janeiro ; Edições de Janeiro, 2015.

MOURA, C. A. S. "Restaurar Todas as Coisas em Cristo": Dom Sebastião Leme e os diálogos com os intelectuais durante o movimento de recatolização no Brasil. In: RODRIGUES, Cândido M.;PAULA, C. J. (Org). Intelectuais e Militância Católica no Brasil. Cuiabá: EdUFMT, 2012.

NAGLE, Jorge. Educação e Sociedade na Primeira República. São Paulo: EPU; Rio de Janeiro, Fundação Nacional de Material Escolar, 1974.

NEVES, Margarida de Souza. Brasil, acertai vossos ponteiros. In: MUSEU DE ASTRONOMIA E AFINS. Brasil, acertai vossos ponteiros. Rio de Janeiro: MAST, 1991.

NEVES, Margarida de Souza. História da Crônica,Crônica da História. In: RESENDE, Beatriz (Org.). Cronistas do Rio. Rio de Janeiro, José Olympio, 1995.

NEVES, Margarida de Souza. "Uma capital em trompe l'oeil. O Rio de Janeiro,cidade-capital da República Velha.” IN MAGALGI, Ana Maria et allii. Educação no Brasil: História, cultura e política. Bragança Paulista: EDUSF, 2003, pp. 253-286. 
NEVES, Margarida de Souza; BYINGTON, Silvia Ilg (Orgs.) Igreja do Sagrado

Coração de Jesus: fé, arte e memória. Rio de Janeiro: Núcleo de Memória da PUC-Rio, 2017.

NORA, Pierre. Entre Memória e História: a problemática dos lugares. Projeto História, v.10, p. 7-28, dez.1993.

PAIM-COSTA, Vicente (coord.). Colégio Santo Inácio 1903 - 2003: uma história que começou com o primeiro colégio carioca. Rio de Janeiro: Colégio Santo Inácio, 2004.

PADOVANI, Umberto; CASTANGNOLA, Luís. História da Filosofia. São Paulo: Melhoramentos, 1990.

PIO X. E Supremi: encyclical of Pope Pius $X$ on the restoration of all things in Christ. Disponível em $<\mathrm{http}$ ://w2.vatican.va/content/pius-

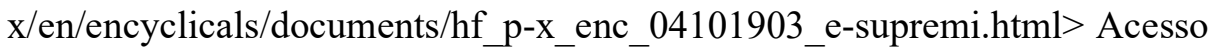
em: 26 abr. 2017.

PIO XI. Carta Encíclica “Quadragesimo Anno” de sua santidade PapaPio XI. Disponível em: $\quad<$ http://w2.vatican.va/content/piusxi/pt/encyclicals/documents/hf_p-xi_enc_19310515_quadragesimoanno.html.> Acesso em: 26 abrl.2017.

POCOCK, J. G. A. Quentin Skinner: a história da política e a política da história. Topoi, v.13, n.25, jul./dez. 2012, p. 193-206.

RAMA, Angel. A Cidade das Letras. São Paulo: Boitempo, 2015.

REIS, Vera Lúcia dos. O Perfeito Escriba: política e letras em Alceu Amoroso Lima. São Paulo: Annablume, 1998. 230p.

RODRIGUES, Antônio Edmilson Martins. Em Algum Lugar do Passado. In: AZEVEDO, André Nunes de (org). Anais do Seminário Rio de Janeiro: capital e capitalidade. Rio de Janeiro:UERJ, 2002.

RODRIGUES. Antonio Edmilson Martins. Que 22, que nada... Revista de $\begin{array}{llll}\text { História. } & 2012 . & \text { Disponível em }\end{array}$ http://www.revistadehistoria.com.br/secao/artigos-revista/que-22- que-nada >. Acesso em: 10 set 2016.

RODRIGUES, Antônio Edmilson Martins. A Costura da Cidade. Rio de Janeiro: Bazar do Tempo, 2016. 
RODRIGUES, Leandro Garcia. Mário de Andrade e Alceu Amoroso Lima correspondência, (des)harmonia e vida literária. Letras de Hoje, vol. 49, n. 2, p. 154-162, abr/jun. 2014.

RODRIGUES, Leandro Garcia (org.). Drummond \& Alceu: Correspondencia de Carlos Drummond de Andrade e Alceu Amoroso Lima. Belo Horizonte: UFMG, 2014.

SALEM, Tânia. Do Centro Dom Vital à Universidade Católica. In: SCHWARTZMAN, Simon (Org.). Universidades e Instituições Científicas no Rio de Janeiro. Brasília: Conselho Nacional de Desenvolvimento Científico e Tecnológico (CNPq), 1982, p. 97-134. Disponível em $<$ http://www.schwartzman.org.br/simon/rio/tania.htm> Acesso em: 02 jun. 2015.

SANTIAGO, Silviano. A permanência do discurso da tradição no modernismo. In: Nas Malhas da Letra. São Paulo: Companhia das Letras, 1989.

SEVCENKO, Nicolau. Literatura como Missão. São Paulo: Editora Brasiliense, 1989.

SEVCENKO, Nicolau. Orfeu Extático na Metrópole. São Paulo : Companhia de Letras, 1992. 390p.

SUSSEKIND, Flora. Cinematografo das Letras: literatura, técnica e modernização no Brasil. São Paulo: Companhia das Letras, 1987.

SKINNER, Quentin. Visões da Política: sobre os métodos históricos. Algés: DIFEL, 2005.

SOUZA, Vanderlei Sebastião de. Autor, Texto e Contexto: a história intelectual e o "contextualismo linguístico" na perspectiva de Quentin Skinner. Fênix Revista de História e Estudos Culturais, out./Nov./dez. 2008, ano V, vol.5, n.4.

VELHO, Gilberto. Memória, Identidade e projeto. In.:Projeto e Metamorfose. Rio de Janeiro: Jorge Zahar Editor, 1994.

VELlosO, Mônica Pimenta. A Ordem: Uma revista de doutrina, política e cultura católica. Revista de ciência política da FGV, Rio de Janeiro, jul./set. 1978.

VELLOSO, Monica Pimenta. O modernismo e a questão nacional. In: FERREIRA, Jorge; DELGADO, Lucília de A. N (orgs.). O Brasil 
republicano. O tempo da experiência democrática. Vol.3. Rio de Janeiro: Civilização Brasileira, 2008.

VILLAÇA, Antonio Carlos. O Pensamento Católico no Brasil. Rio de Janeiro: Zahar Editores, 1975. 


\section{Notas}

\section{Introdução}

${ }^{1}$ cf. COSTA, Marcelo da Silva Timotheo da. Um itinerário no século: mudança, disciplina e ação em Alceu Amoroso Lima. Rio de Janeiro: Ed. PUC-Rio; São Paulo: Loyola, 2006. \& REIS, Vera Lúcia dos. O Perfeito Escriba: política e letras em Alceu Amoroso Lima. São Paulo: Annablume, 1998. 230pp.

${ }^{2}$ LIMA, Cláudio de Medeiros. Alceu Amoroso Lima, Memórias Improvisadas - Diálogos com Medeiros Lima. Petrópolis: Vozes, 1973. 334pp.

${ }^{3}$ Idem. Ibidem. p. 37.

${ }^{4}$ Idem. Ibidem. p. 41.

${ }^{5}$ VILLAÇA, Antonio Carlos. O Pensamento Católico no Brasil. Rio de Janeiro: Zahar Editores, 1975.

${ }^{6}$ GOUVEIA, Saulo. The Catholic crusader and the folklorist: Alceu Amoroso Lima and Mário de Andrade as founding fathers of modernist criticism and historiography. Chasqui: Revista de literatura latino-americana, vol. 41, n. 1, p. 37-58, 2012.

${ }^{7}$ LIMA, Cláudio de Medeiros. Op. Cit. p. 45.

${ }^{8}$ Idem. Ibidem. p. 120.

${ }^{9}$ Idem. Ibidem.

${ }^{10}$ GOUVEIA, Saulo. Op. Cit. p. 50.

${ }^{11}$ RAMA, Angel. A Cidade das Letras. São Paulo: Boitempo, 2015.

${ }^{12}$ Idem. Ibidem. p. 47.

${ }^{13}$ Apud: REIS, Vera Lúcia dos. Op. Cit. p. 21.

\section{Capítulo 1}

${ }^{14}$ O Jornal, ano IV, no 928,28 de jan. de 1922, p. 3.

${ }^{15}$ Correio da Manhã, ano XXI, no 8366,28 de jan. de 1922 p. 1.

${ }^{16}$ NEVES, Margarida de Souza. As vitrines do progresso. Rio de Janeiro: PUC,-Rio/ Departamento de História, 1986.

${ }^{17}$ O Jornal, ano IV, $\mathrm{n}^{\mathbf{0}}$ 929, 29 de jan. de 1922, p. 1.

18 cf.SEVCENKO, Nicolau. Orfeu Extático na Metrópole. São Paulo : Companhia de Letras, 1992. 390pp.

${ }^{19}$ BARBOSA, Francisco de Assis (org.). Intelectuais na Encruzilhada: Correspondência de Alceu Amoroso Lima e António de Alcântara Machado (1927 - 1933). Rio de Janeiro: Academia Brasileira de Letras, 2002. P. XXVI.

${ }^{20}$ Athayde, Tristão de. Adeus à Disponibilidade, A Ordem, Ano VIII, no 1, dez. 1928, p. 57.

${ }^{21}$ LIMA, Alceu Amoroso. Tentativa de Itinerário. In: Adeus à disponibilidade e outros adeuses. Rio de Janeiro: Agir, 1969.

${ }^{22}$ MICELI, Sergio. Intelectuais à brasileira. São Paulo: Companhia das Letras, 2001. p. 11.

${ }^{23}$ Apud SEVCENKO, Nicolau. Op. Cit. p. 300-301.

${ }^{24}$ Idem. Ibidem. p. 301.

${ }^{25}$ Idem. Ibidem.

${ }^{26}$ ATHAYDE, Tristão de. Crônica Literária. A Ordem, Edição Especial, mar. 1929, p. 369.

${ }^{27}$ Idem. Ibidem. p. 370.

${ }^{28}$ LIMA, Alceu Amoroso. Op. Cit. p. 31.

${ }^{29}$ SEVCENKO, Nicolau. Op. Cit. p. 300.

${ }^{30}$ DE DECCA, Edgar Salvadori. O Silêncio dos Vencidos. São Paulo: Editora Brasiliense, 1986. p. 81.

${ }^{31}$ JUNIOR, Mário Cleber Martins Lanna. Tenentismo e Crises Políticas na Primeira República. In: FERREIRA, Jorge; DELGADO, Lucilia de A. N. (org). O Brasil republicano - O tempo do Liberalismo Excludente: da Proclamação da República à Revolução de 1930 Vol. 1. Rio de Janeiro: Civilização Brasileira, 2003.

${ }^{32}$ DE DECCA, Edgar Salvadori. Op. Cit. p. 81-82.

${ }^{33}$ LANNA JUNIOR, Mário Cleber Martins. Op. Cit. p. 349.

${ }^{34}$ VARGAS, Getúlio. O Governo Trabalhista do Brasil. Apud: SEVCENKO, Nicolau. Op. Cit. p. 306.

${ }^{35}$ VELLOSO, Monica Pimenta. Os Intelectuais e a Política Cultural do Estado Novo. In: FERREIRA, Jorge; DELGADO, Lucilia de A. N (org). O Brasil republicano - O Tempo 
do Nacional Estatismo:do início da década de 1930 ao apogeu do Estado Novo. Vol. 2. Rio de Janeiro: Civilização Brasileira, 2003. p. 153 e 154.

${ }^{36}$ Idem. Ibidem. p. 171.

${ }^{37}$ GOUVEIA, Saulo. The Catholic crusader and the folklorist: Alceu Amoroso Lima and Mário de Andrade as founding fathers of modernist criticism and historiography. Chasqui: Revista de literatura latino-americana, vol. 41, $\mathrm{n}^{\circ} .1$, p. 37a58, 2012.

${ }^{38}$ FERREIRA, Marieta de Moraes; PINTO, Surama Conde Sá. A crise dos anos 1920 e a Revolução de 1930. In: FERREIRA, Jorge; DELGADO, Lucilia de A. N (org). O Brasil republicano - O tempo do Liberalismo Excludente: da Proclamação da República à Revolução de 1930 Vol. 1. Rio de Janeiro: Civilização Brasileira, 2003. p. 410.

${ }^{39}$ Posição. A Ordem, Ano XI, Vol. V, nº 11, jan. 1931, p. 3.

${ }^{40}$ ATHAYDE, Tristão de. Indicações. A Ordem, Ano X, Vol. III, nº 10, dez 1930. p. 195.

${ }^{41}$ VIANNA, Marly de Almeida G. O PCB, a ANL e as insurreições de novembro de 1935. In: FERREIRA, Jorge; DELGADO, Lucilia de A. N. (org). O Brasil republicano - O Tempo do Nacional Estatismo:do início da década de 1930 ao apogeu do Estado Novo. Vol. 2. Rio de Janeiro: Civilização Brasileira, 2003. p. 69.

${ }^{42}$ Manifesto Pioneiros da educação nova. Revista HISTEDBR On-line, Campinas, $n^{\text {o }}$ especial, ago. 2006, p. 188.

${ }^{43}$ PANDOLFI, Dulce Chaves. Os anos 1930: as incertezas do regime. In: FERREIRA, Jorge; DELGADO, Lucilia de A. N. (org). Op. Cit. p. 26-27.

${ }^{44}$ Posição. A Ordem, Ano XI, Vol. V, no 11, jan. 1931, p. 05.

${ }^{45}$ REIS, Vera Lúcia dos. O Perfeito Escriba: política e letras em Alceu Amoroso Lima. São Paulo: Annablume, 1998. p. 184.

${ }^{46}$ FAUSTO, Boris. História do Brasil. São Paulo: Editora da Universidade de São Paulo, 2015. (Didática, 1). p. 273.

${ }^{47}$ MICELI, Sérgio. Op. Cit. p. 77.

${ }^{48}$ FAUSTO, Boris. Op. Cit. p. 261.

${ }^{49}$ Idem. Ibidem. p. 260.

${ }^{50}$ NEVES, Margarida de Souza. Brasil, acertai vossos ponteiros. In: MUSEU DE ASTRONOMIA E AFINS. Brasil, acertai vossos ponteiros. Rio de Janeiro: MAST, 1991. p. 53 a 65.

${ }^{51}$ NEVES, Margarida de Souza. "Uma capital em trompe l'oeil. O Rio de Janeiro,cidade-capital da República Velha.”. In: MAGALGI, Ana Maria et allii. Educação no Brasil: História, cultura e política. Bragança Paulista: EDUSF, 2003, pp. 253 a 286.

52 RODRIGUES, Antônio Edmilson Martins. A Costura da Cidade. Rio de Janeiro: Bazar do Tempo, 2016. p. 130.

${ }^{53}$ Idem. Ibidem. p. 147.

${ }^{54}$ RAMA, Angel. A Cidade das Letras. São Paulo: Boitempo, 2015.

${ }^{55}$ FAUSTO, Boris. Op. Cit. p. 261 a 262.

${ }^{56}$ Idem. Ibidem. p. 262.

${ }^{57}$ FERREIRA, Marieta de Moraes; PINTO, Surama Conde Sá. Op. Cit. p. 396.

${ }^{58}$ Literalmente "engana o olho". Tipo de pintura surgida no fim do século XIX que criava efeitos de profundidade e de texturas a partir de ilusões gráficas.

${ }^{59}$ VELLOSO, Mônica Pimenta. O modernismo e a questão nacional. In: FERREIRA, Jorge; DELGADO, Lucilia de A. N (org). O Brasil republicano - O tempo do Liberalismo Excludente: da Proclamação da República à Revolução de 1930 Vol. 1. Rio de Janeiro: Civilização Brasileira, 2003. p. 360.

${ }^{60}$ Idem. Ibidem. p. 362.

${ }^{61}$ MICELI, Sergio. Op. Cit. p. 104.

${ }^{62}$ ATHAYDE, Tristão de. Literatura Suicida. O Jornal, ano VII, nº 2001, 28 de junho de 1925, p. 4.

${ }^{63}$ FERREIRA, Marieta de Moraes; PINTO, Surama Conde Sá. Op. Cit. p. 396 e 397.

${ }^{64}$ FAUSTO, Boris. Op. Cit. p. 263.

${ }^{65}$ FERREIRA, Marieta de Moraes; PINTO, Surama Conde Sá. Op. Cit. p. 398.

${ }^{66}$ Idem. Ibidem. p. 399.

${ }^{67}$ Idem. Ibidem. p. 402.

${ }^{68}$ LANNA JUNIOR, Mário Cleber Martins. Op. Cit. p. 346.

${ }^{69}$ Idem. Ibidem.

${ }^{70}$ Idem. Ibidem. p. 316.

${ }^{71}$ FAUSTO, Boris. Op. Cit. p. 264. 
72 cf.: MICELI, Sérgio. Op. Cit. e SEVCENKO, Nicolau. Op. Cit.

73 cf.: FAUSTO, Boris. Op. Cit. e FERREIRA, Marieta de Moraes; PINTO, Surama Conde Sá. Op. Cit.

${ }^{74}$ SEVCENKO, Nicolau. Op. Cit. p. 300.

${ }^{75}$ FERREIRA, Marieta de Moraes; PINTO, Surama Conde Sá. Op. Cit. p. 403-404.

${ }^{76}$ DE DECCA, Edgar. Op. Cit.

${ }^{77}$ ATHAYDE, Tristão de. Palavras aos Companheiros. A Ordem, Ano X, Vol. III, n . 9, out 1930. p. 101.

${ }^{78}$ Idem. Ibidem.

${ }^{79}$ MARIA, Júlio. A Igreja e a República. Brasília: Editora Universidade de Brasília, c. 1921.

${ }^{80}$ SALEM, Tânia. Do Centro Dom Vital à Universidade Católica. In: SCHWARTZMAN, Simon (Org.). Universidades e Instituições Científicas no Rio de Janeiro. Brasília: Conselho Nacional de Desenvolvimento Científico e Tecnológico (CNPq), 1982, p. 97-134. Disponível em $<$ http://www.schwartzman.org.br/simon/rio/tania.htm $>$ Acesso em: 02 jun. 2015.

${ }^{81}$ Carta Pastoral do Cardeal D. Leme quando Arcebispo de Olinda, saudando os seus diocesanos. In: DIAS, Roberto Barros. "DEUS E A PÁTRIA": Igreja e Estado no processo de Romanização na Paraíba (1894-1930). João Pessoa, 2008. (Mestrado em História) - Centro de Ciências Humanas, Letras e Artes, Universidade Federal da Paraíba. p. 201 e 203.

82 VILLAÇA, Antonio Carlos. O Pensamento Católico no Brasil. Rio de Janeiro: Zahar Editores, 1975. p. 85.

${ }^{83}$ MARIA, Júlio. Op. Cit. p. 103.

${ }^{84}$ BEOZZO, José Oscar. A Igreja entre a Revolução de 1930, o Estado Novo e a Redemocratização. Apud: AQUINO, Mauricio de. A implantação da república e a Igreja no Brasil e em Portugal: o caso das congregações femininas portuguesas em diáspora (19111921). Revista Brasileira de História das Religiões, Ano IV, $\mathrm{n}^{\circ}$ 10, maio 2011. p. 218.

${ }^{85}$ cf.: MONTALBAN, Francisco J. Historia de La Iglesia Católica: IV Edad Moderna - La Iglesiaensu Lucha y Relaciónconel Laicismo. Madrid: Biblioteca de Autores Cristianos, 1963. p. 649. \& AQUINO, Mauricio de. Op. Cit. p. 215-232.

${ }^{86}$ AQUINO, Mauricio de. Op. Cit.

${ }^{87}$ AZZI, R. A Neocristandade: Um Projeto Restaurador. São Paulo: Paulus, 1994 - (História do pensamento católico no Brasil; v. 5). p. 62.

${ }^{88}$ Idem. Ibidem.

${ }^{89}$ Idem. Ibidem. p. 71.

${ }^{90}$ Idem. Ibidem. p. 23.

${ }^{91}$ PIO X. E Supremi: encyclical of Pope Pius X on the restoration of all things in Christ. Disponível em: $<$ http://w2.vatican.va/content/pius-x/en/encyclicals/documents/hf_px enc_04101903_e-supremi.html> Acesso em: 25 jun. 2015. (Tradução livre).

${ }^{92}$ MOURĀ, C. A. S. "Restaurar Todas as Coisas em Cristo": Dom Sebastião Leme e os diálogos com os intelectuais durante o movimento de recatolização no Brasil. In: RODRIGUES, Cândido M.; PAULA, C. J. (Org). Intelectuais e Militância Católica no Brasil. Cuiabá: EdUFMT, 2012. p. 18.

${ }^{93}$ GRAMSCI, A. "Maquiavel, a política e o Estado moderno". Apud: CASALI, Alípio. Elite Intelectual e Restauração da Igreja. Petrópolis: Vozes, 1995, p. 24.

94 "'We proclaim that We have no other program in the Supreme Pontificate but that of restoring all things in Christ' (Ephes. I, 10), so that 'Christ may be all and in all' (Coloss. III, 2)". In: PIO X. Op. Cit. (Tradução livre).

${ }^{95}$ AZZI, R. op. cit. p. 21-22.

${ }^{96}$ Idem. Ibidem. p. 22.

${ }^{97}$ Idem. Ibidem.

${ }^{98}$ AZZI, R. op. cit. p. 33.

99 ARDUINI, Guilherme Ramalho. Em Busca da Idade Nova: Alceu Amoroso Lima e os Projetos Católicos de Organização social (1928-1945). São Paulo: Editora da Universidade de São Paulo, 2015.p. 42.

${ }^{100}$ CASALI, Alípio. op. cit. p. 81.

${ }^{101}$ AZZI, R. op. cit. p. 69.

${ }^{102}$ Idem. Ibidem.

${ }^{103}$ ARDUINI, Guilherme Ramalho. op. cit. p. 43.

${ }^{104}$ VILLAÇA, Antonio Carlos. Op. Cit. p. 13. 
${ }^{105}$ SEVCENKO, Nicolau. Op. Cit. p. 32.

${ }^{106}$ cf. SUSSEKIND, Flora. Cinematógrafo das Letras: literatura, técnica e modernização no Brasil. São Paulo: Companhia das Letras, 1987.

${ }^{107}$ SEVCENKO, Nicolau. Op. Cit. p. 35.

${ }^{108}$ BARBOSA, Francisco de Assis (org.). Op. Cit. p. 108.

${ }^{109}$ Idem. Ibidem. p. 121.

${ }^{110}$ Idem. Ibidem. p. 121.

${ }^{111}$ Idem. Ibidem. p. 101.

${ }^{112}$ Idem. Ibidem. p. 99.

${ }^{113}$ SOUZA, Vanderlei Sebastião de. Autor, Texto e Contexto: a história intelectual e o "contextualismo linguístico" na perspectiva de Quentin Skinner. Fênix - Revista de História e Estudos Culturais, out./Nov./dez. 2008, ano V, vol.5, n.4.

${ }^{114}$ AUSTIN, John Langshaw. Quando dizer é fazer. Porto Alegre: Artes Médicas, 1990.

${ }^{115}$ GINZBURG, Carlo. Sinais: raízes de um paradigma indiciário.In: Mitos, emblemas, sinais: Morfologia e História. São Paulo: Companhia das letras, 1987. p. 143 a 179.

${ }^{116}$ GEERTZ, Clifford. A Interpretação das Culturas. Rio de Janeiro: LTC, 2008. p. 10.

${ }^{117}$ SEVCENKO, Nicolau. Op. Cit. p. 197.

${ }^{118}$ Idem. Ibidem. 181.

${ }^{119}$ MORAES, Eduardo Jardim de. Modernismo Revisado. Estudos Históricos, v.1, nº 2, 1988.

${ }^{120}$ TELES, Gilberto Mendonça. Vanguarda europeia e modernismo brasileiro: apresentação dos principais poemas, manifestos, prefácios e conferências vanguardistas, de 1857 até hoje. Rio de Janeiro: Record, 1987. 10 Ed. p. 294.

${ }^{121}$ Idem. Ibidem. p. 295.

${ }^{122}$ Idem. Ibidem. p. 296.

${ }^{123}$ JARDIM, Eduardo. A brasilidade modernista - sua dimensão filosófica. Rio de Janeiro: Editora PUC-Rio, Ponteiro, 2016. Edição revisada e atual.

${ }^{124}$ PAZ, Octávio. Os Filhos do Barro: do romantismo à vanguarda. Rio de Janeiro: Nova Fronteira, 1984.

${ }^{125}$ TELES, Gilberto Mendonça. Op. Cit. p. 326.

${ }^{126}$ Idem. Ibidem. p. 327.

${ }^{127}$ Idem. Ibidem. p. 329.

${ }^{128}$ Idem. Ibidem. p. 330.

${ }^{129}$ Idem. Ibidem. p. 353.

${ }^{130}$ Idem. Ibidem. p. 356.

${ }^{131}$ Idem. Ibidem. p. 357.

${ }^{132}$ Idem. Ibidem. p. 360.

${ }^{133}$ Idem. Ibidem.

${ }^{134}$ JARDIM, Eduardo. Op. Cit.

${ }^{135}$ MORAES, Eduardo Jardim de. Modernismo Revisado. Estudos Históricos, v.1, n², 1988. p. 235.

${ }^{136}$ Idem. Ibidem. p. 237.

Capítulo 2

${ }^{137}$ NOGUEIRA, Hamilton. Apud: RODRIGUES, Leandro Garcia (org.). Drummond \& Alceu: Correspondência de Carlos Drummond de Andrade e Alceu Amoroso Lima. Belo Horizonte: UFMG, 2014. p.30.

${ }^{138}$ ETIENNE FILHO, João (org.). Correspondência: Harmonia dos Contrastes (1919 - 1928) Tomo 1. Rio de Janeiro: Academia Brasileira de Letras, 1991. p. 15.

${ }^{139}$ TODARO, Margareth. Pastors, prophets and politicians. Apud: ARDUINI, Guilherme Ramalho. Em Busca da Idade Nova: Alceu Amoroso Lima e os Projetos Católicos de Organização social (1928-1945). São Paulo: Editora da Universidade de São Paulo, 2015. p. 23.

${ }^{140}$ ARDUINI. Op. Cit.

${ }^{141}$ A Ordem, Vol. $1 \mathrm{n}^{\circ}$ 1, 1921, p. 1.

${ }^{142}$ Idem. Ibidem. p. 2.

${ }^{143}$ VELLOSO, Mônica Pimenta. A Ordem: Uma revista de doutrina, política e cultura católica. Revista de ciência política da FGV, Rio de Janeiro, jul./set. 1978. p. 120 a 121.

${ }^{144}$ Idem. Ibidem. p. 123.

${ }^{145}$ A Ordem. Op. Cit. 
${ }^{146}$ VELLOSO, Monica Pimenta. Op. Cit. p. 124.

${ }^{147}$ MARIA, Júlio. A Igreja e a República. Brasília: Editora Universidade de Brasilia, c. 1921. p. 119.

${ }^{148}$ VILLAÇA, Antonio Carlos. O Pensamento Católico no Brasil. Rio de Janeiro: Zahar Editores, 1975. p. 97.

${ }^{149}$ Idem. Ibidem. p. 103.

${ }^{150}$ Idem. Ibidem. p. 97.

${ }^{151}$ VELLOSO, Monica Pimenta. Op. Cit. p. 129

${ }^{152}$ ARDUINI, Guilherme Ramalho. O Centro Dom Vital: estudo de caso de um grupo de intelectuais católicos no Rio de Janeiro entre os anos 1920 e 1940. In: RODRIGUES, Cândido M.; PAULA, C. J. (Org). Intelectuais e Militância Católica no Brasil. Cuiabá: EdUFMT, 2012. p. 48.

${ }^{153}$ Idem. Ibidem.

${ }^{154}$ SALEM, Tânia. Do Centro Dom Vital à Universidade Católica. In: SCHWARTZMAN, Simon (Org.). Universidades e Instituições Científicas no Rio de Janeiro. Brasília: Conselho Nacional de Desenvolvimento Científico e Tecnológico (CNPq), 1982, p. 97-134. Disponível em <http://www.schwartzman.org.br/simon/rio/tania.htm> Acesso em: 08 de out de 2018. p. 5-6.

${ }^{155}$ ATHAYDE, Tristão de. Palavras aos Companheiros. A Ordem, Ano X, Vol. III, nº. 9, out 1930. p. 101.

${ }^{156}$ VILLAÇA, Antonio Carlos. Op. Cit. p. 111.

${ }^{157}$ Idem. Ibidem. p. 113.

${ }^{158}$ A Ordem. Ano I, ${ }^{\circ} 12$, jul. 1922. p. 1.

${ }^{159}$ VELLOSO, Mônica Pimenta. Op.Cit. p. 124.

${ }^{160}$ ATHAYDE, Tristão de. Palavras aos Companheiros. A Ordem, Ano X, Vol. III, nº. 9, out 1930. p. 101.

${ }^{161}$ Idem. Ibidem.

${ }^{162}$ ATHAYDE, Tristão de. Indicações. A Ordem, Ano X, Vol. III, nº 10, dez 1930. p. 194.

${ }^{163}$ Idem. Ibidem. p. 193.

${ }^{164}$ Idem. Ibidem.

${ }^{165}$ Idem. Ibidem. p. 197.

${ }^{166}$ Alceu Amoroso Lima em alocução proferida na Sessão Solene de Instauração dos cursos das Faculdades Católicas. FACULDADES CATÓLICAS. Op. Cit., p. 75.

${ }^{167}$ FACULDADES CATÓLICAS. op. cit., p. 08.

${ }^{168}$ FACULDADES CATÓLICAS. op. cit., p. 05.

${ }^{169}$ Padre Leonel Franca em alocução proferida na Sessão Solene de Instauração dos cursos das Faculdades Católicas. FACULDADES CATÓLICAS. Op. Cit., p. 66 a 67.

${ }^{170}$ A Carta Pastoral de S. Em. Cardeal D. Leme quando Arcebispo de Olinda, saudando os seus diocesanos. In: DIAS, Roberto Barros. op. cit. p. 202.

${ }^{171}$ TODARO, Margareth. Jackson. Apud: ARDUINI, Guilherme Ramalho. ARDUINI, Guilherme Ramalho. Em Busca da Idade Nova: Alceu Amoroso Lima e os Projetos Católicos de Organização social (1928-1945). São Paulo: Editora da Universidade de São Paulo, 2015. p. 23.

${ }^{172}$ SALEM, Tania. Op. Cit.

${ }^{173}$ Idem. Ibidem.

${ }^{174}$ TODARO, Margareth. Pastors, Prophets and Politicians. In: Op. Cit. p. 49.

${ }^{175}$ COSTA, Marcelo da Silva Timotheo da. Um itinerário no século: mudança, disciplina e ação em Alceu Amoroso Lima. Rio de Janeiro: Ed. PUC-Rio; São Paulo: Loyola, 2006. p. 253.

${ }_{177}^{176}$ Idem. Ibidem. p. 255.

${ }^{177}$ Idem. Ibidem. p. 270.

${ }^{178}$ RAMA, Angel. A Cidade das Letras. São Paulo: Boitempo, 2015.

${ }^{179}$ MICELI, Sergio. Intelectuais à brasileira. São Paulo: Companhia das Letras, 2001. p. 124.

${ }^{180}$ Idem. Ibidem. p. 126.

${ }^{181}$ COSTA, Marcelo Timotheo da. Op. Cit. p. 270.

${ }^{182}$ VILLAÇA, Antonio Carlos. Op. Cit. 110.

${ }^{183}$ LIMA, Alceu Amoroso. Tentativa de Itinerário. In: Adeus à disponibilidade e outros adeuses. Rio de Janeiro: Agir, 1969. p. 26.

${ }^{184}$ Idem. Ibidem. p. 20. 
${ }^{185}$ Idem. Ibidem. p. 20-21.

${ }^{186}$ Idem. Ibidem. p. 24.

${ }^{187}$ Idem. Ibidem. p. 25.

${ }^{188}$ Idem. Ibidem.

${ }^{189}$ Idem. Ibidem. p. 29.

${ }^{190}$ ARDUINI, Gulherme Ramalho. Op. Oit. p. 39.

${ }^{191}$ Idem. Ibidem. p. 140.

192 LIMA, Alceu Amoroso. Op. Cit. p. 31.

${ }^{193}$ Idem. Ibidem.

${ }^{194}$ Idem. Ibidem. p. 29 a 30.

${ }^{195}$ Idem. Ibidem. p. 31.

${ }^{196}$ Idem. Ibidem. p. 29.

${ }^{197}$ Idem. Ibidem. p. 28.

${ }^{198}$ VELHO, Gilberto. Memória, Identidade e Projeto. In: Projeto e Metamorfose. Rio de Janeiro: Jorge Zahar Editor, 1994, p. 101.

${ }^{199}$ Idem. Ibidem.

${ }^{200}$ LIMA, Alceu Amoroso. Op. Cit. p. 27 a 28.

${ }^{201}$ VELLOSO, Monica Pimenta. Op. Cit. p. 157.

${ }^{202}$ LIMA, Alceu Amoroso. Introdução à Economia Moderna. Rio de Janeiro: Livraria AGIR Editora, 1956. p. 15 a 16.

${ }^{203}$ ATHAYDE, Tristão de. Política. Rio de Janeiro: Editor Getulio Costa, 1939. p. 196.

${ }^{204}$ Idem. Ibidem. p. 212.

${ }^{205}$ Athayde, Tristão de. Adeus à Disponibilidade. In: Athayde, Tristão de. Adeus à Disponibilidade. A Ordem, Ano VIII, $n^{\circ}$ 1, dez. 1928, p. 56.

${ }^{206}$ Idem. Ibidem. p. 56 a 57.

${ }^{207}$ Idem. Ibidem. p. 59.

${ }^{208}$ ARDUINI, Guilherme Ramalho. Os soldados de Roma contra Moscou: a atuação do Centro Dom Vital no cenário político e cultural brasileiro (Rio de Janeiro, 1922-1948). 2014. Tese (Doutorado em Sociologia) - Faculdade de Filosofia, Letras e Ciências Humanas, Universidade de São Paulo, São Paulo, 2014.

${ }^{209}$ COSTA, Marcelo Timotheo. Op. Cit. p. 86.

${ }^{210}$ ATHAYDE, Tristão de. Traços da Psicologia do Povo Brasileiro. A Ordem, Ano XIV, Vol. XI, $n^{\circ}$ 48. p. 124 .

${ }^{211}$ Idem. Ibidem. p. 140.

${ }^{212}$ Idem. Ibidem. p. 136.

${ }^{213}$ ATHAYDE, Tristão. Formação do Brasil. Vida Literária. O Jornal, 05 de outubro de 1930. p. 4.

${ }^{214}$ Idem. Ibidem.

${ }^{215}$ MARIA, Júlio. Op. Cit. p. 65.

${ }^{216}$ Idem. Ibidem. p. 9.

${ }^{217}$ Idem Ibidem.

${ }^{218}$ Idem. Ibidem. p. 31.

${ }^{219}$ Idem. Ibidem. p. 29.

${ }^{220}$ Idem. Ibidem. p. 51.

${ }^{221}$ Idem. Ibidem. p. 97 e 102.

222 cf. ATHAYDE, Tristão de. O Anjo da Escada e os Professores. A Ordem, Ano 9, Vol. II, set. 1929 , pp. 80 a 98.

${ }^{223}$ ATHAYDE, Tristão de. Instituto Católico de Estudos Superiores. A Ordem, Ano XII, Vol. VII, ${ }^{\circ} 28$, jun. 1932, p. 415.

${ }^{224}$ ATHAYDE, Tristão de. Instituto Católico de Estudos Superiores. A Ordem, Ano XII, Vol. VII, $n^{\circ} 28$, jun. 1932, p. 415.

${ }^{225}$ Idem. Ibidem. p. 22.

${ }^{226}$ Idem. Ibidem.

${ }^{227}$ Idem. Ibidem. p. 24.

${ }^{228}$ ARAÚJO, Ricardo Benzaquen de. Totalitarismo e Revolução - o integralismo de Plínio Salgado. Rio de Janeiro: Jorge Zahar Editor, 1988. p. 50.

${ }^{229}$ Idem. Ibidem. p. 35.

${ }^{230}$ Idem. Ibidem. p. 37. 
${ }^{231}$ ATHAYDE, Tristão de. O Anjo da Escada e os Professores. A Ordem, Ano 9, Vol. II, set. 1929 , p. 84.

${ }^{232}$ Idem. Ibidem. p. 96.

${ }^{233}$ ATHAYDE, Tristão de. Seu Lugar. A Ordem, Ed. Especial, mar. 1929, p. 346.

${ }^{234}$ Idem. Ibidem.

${ }^{235}$ Idem. Ibidem. p. 347.

${ }^{236}$ A Ordem, Ed. Especial, mar. 1929. p. 1

${ }^{237}$ ARDUINI, Guilherme Ramalho. Op. Cit.

${ }^{238}$ ATHAYDE, Tristão de. O Patriarca. A Ordem, Ano XI, Vol. VI, n 19, set. 1931, p. 158.

${ }^{239}$ Idem. Ibidem.

${ }^{240}$ ATHAYDE, Tristão de. A Comemoração de Anchieta. A Ordem, Ano XIV, Vol. XI, n 50, abr. 1934, p. 259.

${ }^{241}$ Idem. Ibidem. p. 260.

${ }^{242}$ MARIA, Júlio. Op. Cit. p. 49.

${ }^{243}$ Idem. Ibidem. p. 17.

${ }^{244}$ ATHAYDE, Tristão de. Op. Cit. p. 262.

${ }^{245}$ ATHAYDE, Tristão de. Adeus à Disponibilidade. A Ordem, Ano VIII, nº 1, dez. 1928, p. 57.

${ }^{246}$ ATHAYDE, Tristão de. Oração de Paraninfo. A Ordem, Ano XIII, Vol. X, n 41, nov./dez. 1933, p. 857.

${ }^{247}$ Idem. Ibidem. p. 856.

${ }^{248}$ Idem. Ibidem. p. 858.

${ }^{249}$ Idem. Ibidem. p. 863.

${ }^{250}$ ATHAYDE, Tristão de. Indicações. A Ordem, Ano X, Vol. III, no 10, dez 1930. p. 195.

${ }^{251}$ Dom Celemnte Gouveia Isnard, Sem Titulo, A Ordem, , jan./fev. 1944, p. 12-13. Apud: ARDUINI, Guilherme Ramalho. Em Busca da Idade Nova: Alceu Amoroso Lima e os Projetos Católicos de Organização social (1928-1945). São Paulo: Editora da Universidade de São Paulo, 2015. p. 15.

${ }^{252}$ ARDUINI, Guilherme Ramalho. Op. Cit. p. 88.

${ }^{253}$ Idem. Ibidem. p. 87.

${ }^{254}$ ATHAYDE, Tristão de. Tríplice decálogo. A Ordem, Ano XII, Vol. VIII, n 33, nov. 1932, p. 340 a 344.

${ }^{255}$ Idem. Ibidem. p. 340 a 341.

${ }^{256}$ LEÃO XII. Carta encíclica "Rerum Novarum" do sumo pontífice Papa Leão XII. Disponível em $<$ http://w2.vatican.va/content/leo-xiii/pt/encyclicals/documents/hf_lxiii_enc_15051891_rerum-novarum.html>. Acesso em 26 abr. 2017.

${ }^{257}$ Idem. Ibidem.

${ }^{258}$ MARIA, Júlio. Op. Cit. p. 114.

${ }^{259}$ Padre Leonel Franca em alocução proferida na Sessão Solene de Instauração dos cursos das Faculdades Católicas. FACULDADES CATÓLICAS. Anuário das Faculdades Católicas, 1941. Rio de Janeiro, 1942, p. 68.

${ }^{260}$ LIMA, Alceu Amoroso. Universidade e civilização. A Ordem, ano 8, vol. 20, jul.-dez. de 1938. p. 150.

${ }^{261}$ Manifesto Pioneiros da educação nova. Revista HISTEDBR On-line, Campinas, n. especial, ago. 2006, p. 203.

${ }^{262}$ ATHAYDE, Tristão de. Absolutismo Pedagógico. A Ordem, Ano XII, Vol. VII, n² 26, abr. 1932. p. 317.

${ }^{263}$ Idem. Ibidem. p. 318.

${ }^{264}$ Idem. Ibidem. p. 320.

${ }^{265}$ SERRANO, Jonathas. Letras Católicas. A Ordem, Ano XII, Vol. VII, nº26, abr. 1932, p. 276.

${ }^{266}$ Manifesto Pioneiros da educação nova. Op. Cit. p. 188.

${ }^{267}$ NAGLE, Jorge. Educação e Sociedade na Primeira República. São Paulo: EPU; Rio de Janeiro, Fundação Nacional de Material Escolar, 1974. p. 99 a 100.

${ }^{268}$ DELAMARE, Alcibíades. As Duas Bandeiras. Apud: Idem. Ibidem. p. 105.

${ }^{269}$ SALEM, Tânia. Op. Cit.

${ }^{270}$ Idem. Ibidem.

${ }^{271}$ MESQUIDA, Peri. Educação na Restauração Lemista da Igreja: a missão de Tristão de Athayde e Stella de Faro no Ministério da Educação e Saúde Pública. In: Revista Diálogo Educacional, v. 9, n. 27, p. 279-295, maio/ago. 2009. p. 285. 
${ }^{272}$ RODRIGUES, Leandro Garcia (org.). Drummond \& Alceu: Correspondência de Carlos Drummond de Andrade e Alceu Amoroso Lima. Belo Horizonte: UFMG, 2014.

${ }^{273}$ Idem. Ibidem. p. 48.

${ }^{274}$ MESQUIDA, Peri. Op. Cit. p. 288.

${ }^{275}$ ATHAYDE, Tristão de. Instituto Católico de Estudos Superiores. A Ordem, Ano XII, Vol. VII, n 28 , jun. 1932. p. 421.

${ }^{276}$ ATHAYDE, Tristão de. Os Perigos da Vitória. A Ordem, Ano XIV, Vol. XII, n ${ }^{\circ 3}$, jul. 1934, p. 3.

${ }^{277}$ ATHAYDE, Tristão de. O Sentido de Nossa Vitória. A Ordem, Ano XIV, Vol. XI, n 52, jun. 1934, p. 419.

278 cf. COSTA, Marcelo Timotheo. Op. Cit.

${ }^{279}$ Posição. A Ordem, Ano XI, Vol. V, no 11, jan. 1931, p. 03.

${ }^{280}$ Suicídio da Burguesia. A Ordem, Ano XI, Vol. V, n 12, fev. 1931.

${ }^{281}$ Agonia da Burguesia. A Ordem, Ano XI, Vol. V, n 13, mar. 1931.

${ }^{282}$ A Salvação da Burguesia. A Ordem, Ano XI, Vol. V, n 14, abr. 1931.

${ }^{283}$ ATHAYDE, Tristão de. Problema da Burguesia. Rio de Janeiro: Schmidt editor, 1932.

${ }^{284}$ Educação Religiosa. A Ordem, Ano XI, Vol. V, nº 15, mai. 1931, p. 257.

${ }^{285}$ Monismo Sindicalista. A Ordem, Ano XI, Vol. V, no 16, jun. 1931, p. 324.

${ }^{286}$ Idem. Ibidem. p. 322 a 323.

${ }^{287}$ Idem. Ibidem. p. 325.

${ }^{288}$ A Igreja e o Estado. A Ordem, Ano XI, Vol. VI, no 17, jul. 1931, p. 5.

${ }^{289}$ A Cruzada. A Ordem, Ano XI, Vol. VI, no 22, dez. 1931, p. 328.

${ }^{290}$ Dever Político. A Ordem, Ano XII, Vol. VII, n 25, jan. 1932.

${ }^{291}$ Texto apresentado no $56^{\circ}$ Congresso Internacional de Americanistas, em processo de publicação.

\section{Conclusão}

${ }^{292}$ BARBOSA, Francisco de Assis (org.). Intelectuais na Encruzilhada: Correspondência de Alceu Amoroso Lima e António de Alcântara Machado (1927 - 1933). Rio de Janeiro: Academia Brasileira de Letras, 2002.

${ }^{293}$ DARNTON, Robert. O grande massacre de gatos, e outros episódios da história cultural francesa. Rio de Janeiro: Graal, 1986. p. 106. 